\title{
64. MESOZOIC-CENOZOIC DEPOSITIONAL ENVIRONMENTS REVEALED BY DEEP SEA DRILLING PROJECT LEG 93 DRILLING ON THE CONTINENTAL RISE OFF THE EASTERN UNITED STATES: CRUISE SUMMARY ${ }^{1}$
}

\author{
Sherwood W. Wise, Jr., Department of Geology, Florida State University \\ and \\ Jan E. van Hinte, Instituut voor Aardwetenschappen, Vrije Universiteit, Amsterdam²
}

\begin{abstract}
DSDP Leg 93 drilled deep holes on both the lower and upper continental rise along the U.S. Atlantic margin to provide sections that could be correlated with commercial wells on land and offshore and with subsequent DSDP Leg 95 holes along the "New Jersey Transect," and to contribute to the first downdip suite of drill holes across a passive continental margin from the coastal plain to the abyssal plain.

Site 603 on the lower rise intersected an extensive Lower Cretaceous deep-sea fan complex which provides new information on the geologic history and petroleum potential of the rise. Valanginian to early Aptian in age, this $298-\mathrm{m}$ interval of sand and black shale turbidites interbedded with limestones testifies to the apparent absence of post-Valanginian shelf-edge carbonate reefs along the Baltimore Canyon Trough. Fan development during the Hauterivian-early Barremian coincided with deltaic progradation across the adjacent shelf, apparently in response to tectonic uplift along the Appalachian Mountain trend, coupled with a change to a more humid climate. The present evidence indicates that the largest source of siliciclastics passed through the Salisbury Embayment and across the southern Baltimore Canyon Trough to the shelf edge, where the sediments were essentially fed directly into the deep-sea environment. A massive, largely unconsolidated sand unit at the top of the fan sequence, however, was emplaced during a short-term episode of shelf destruction, which we attribute to a major sea-level lowering during the early Aptian (base of Vail Supercycle LZB-4).

Less extensive terrigenous turbidites were encountered as far up in the section as the Cretaceous/Tertiary (K/T) boundary. The K/ $\mathrm{T}$ boundary appears to be marked by a current-laminated sand turbidite rich in dark spherules, $1 \mathrm{~mm}$ in diameter and now composed of montmorillonite, which may denote an extraterrestrial impact event.

DSDP Sites 604 and 605 are located on the upper continental rise. Hole 605 , drilled $816.7 \mathrm{~m}$ to upper Maestrichtian limestones, penetrated a nearly complete K/T boundary section, above which $20 \mathrm{~m}$ of lower Paleocene limestones are separated by a disconformity from an expanded $177-\mathrm{m}$ Paleocene sequence. Terrigenous silts and glauconite at the $\mathrm{K} / \mathrm{T}$ boundary and immediately above suggest that either significant sea-level change, increased current erosion along the adjacent shelf and slope, increased terrigenous input caused by decreased vegetation, a high-energy event (tsunami?), progradation of local deltas, or some combination of these possible factors occurred in the basal Danian.

Spectacular debris flows at Site 604 were emplaced during the Messinian and/or the early Tortonian (8.2 to 10.0 Ma; Vail Cycle TB3.1 [formerly TM3.1], which marks the most rapid and profound late Miocene sea-level drop). These upper Miocene sediments contain shelf-derived gravels, exotic blocks of Eocene chalk, up to $50 \mathrm{~cm}$ across, eroded from the adjacent slope, and clasts of middle and upper Miocene carbonates or silts derived from canyon walls or shallow-water strata upslope. Study of seismic profiles and correlation with seismic reflection Horizon $\mathrm{M}_{2}$ /Merlin on the lower rise suggest that large-scale regional erosion (canyon cutting), which is related to the debris flows, began at about the middle/late Miocene boundary. This erosional episode appears to be linked with Southern Hemisphere glacial events associated with the formation of the West Antarctic Ice Sheet.

Within the upper Pliocene at Site 604, a hiatus lasting from 2.4 Ma to 2.9 (minimum) or 3.3 (maximum) Ma is correlated with seismic reflection Horizon $\mathrm{P}_{2}$ /Blue and linked to oceanographic events associated with the initiation of Northern Hemisphere continental glaciation and possibly the closure of the Central American Seaway.

On the lower rise (Site 603), turbiditic silts and clays began to accumulate rapidly during the middle Miocene. Under the influence of a strengthening Western Boundary Undercurrent, these were deposited as muddy contourites in "antidune-like" sediment waves, which grew rapidly with no appreciable break in sedimentation until at least early Pleistocene times to form the present lower continental rise hills of the Hatteras Outer Ridge (HOR). The somewhat elevated edge of the lower continental rise terrace formed as a natural levee behind which the coarser portion of the terrigenous turbidites were ponded to form the lower rise terrace. No coarse clastics that bypassed the pond were deposited with the clays of the HOR at this locality.

Throughout this study, seismic sequence boundaries of the upper and lower continental rise have been calibrated and correlated with continental margin unconformities as well as with deep-sea reflection horizons. Our results strongly corroborate the timing and extent of major Vail sequences as well as the reflection surfaces recently mapped in the North American Oceanic Basin.
\end{abstract}

"Many of the most exciting events in the history of our planet have taken place at this contact zone, between continental and oceanic crust, and between continents and oceans; the continental margin represents the stage where, throughout earth history, this drama has been played."

Hollis D. Hedberg, 1970

\footnotetext{
${ }^{1}$ van Hinte, J. E., Wise, S. W., Jr., et al., Init. Repts. DSDP, 93: Washington (U.S. Govt. Printing Office),

${ }^{2}$ Addresses: (Wise) Dept. of Geology, Florida State University, Tallahassee, FL 32306; (van Hinte) Instituut voor Aardwetenschappen, Vrije Universiteit, P.O, Box 7161, 1007 MC Amsterdam. The Netherlands.
} 


\section{INTRODUCTION}

Glomar Challenger left Norfolk, Virginia, on May 4, 1983 , in pursuit of its primary DSDP Leg 93 objective, which was to drill a deep reentry hole on the lower continental rise off North Carolina, U.S.A. The ultimate drilling target at this Atlantic passive margin site was Jurassic oceanic basement. The vessel returned to Norfolk 44 days later (June 17), having drilled both the lower continental rise off North Carolina and the upper continental rise off New Jersey. Its mission and cruise objectives had been changed radically midway through the cruise when the drill string was lost. This incident, though injurious to the primary mission, did little to detract from the ultimate success of the voyage. We first discuss briefly the original mission of the cruise and the modified plan subsequently developed, and then devote the balance of this paper to a narrative summary of the drilling results.

\section{Cruise Plan}

The original cruise plan was developed by the JOIDES Passive Margin Panel, which sought a deep-water site near the western edge of the North American Basin where the youngest Jurassic reflector, $\mathrm{J}_{1}$, and the underlying basement were within reach of the Challenger's $6800-\mathrm{m}$ drill string. The panel recognized that a single, carefully placed hole in this region might sample a nearly complete section dating from shortly after the initial opening of the Atlantic to the present and that the section would record the response of the basin to enlargement and deepening through seafloor spreading and crustal cooling, to the influx of sediments from the continental margin, and to the major current reorganization which took place during the Oligocene.

The site chosen, ENA-3D (designated upon drilling as Site 603 ), was located in some $4600 \mathrm{~m}$ of water at the boundary between the lower continental rise terrace and the lower continental rise hills (Fig. 1). Seismic records indicated that the section was quite complex, with numerous well-defined reflectors which could be traced across most of the basin (Tucholke and Mountain, 1979; Klitgord and Grow, 1980).

The expected stratigraphic sequence as outlined in the cruise prospectus (Fig. 2) could be divided conveniently into two intervals: (1) pre-Horizon $\mathrm{A}^{\mathrm{u}}$ : roughly the lower two-thirds of the sediment column, for the most part exhibiting fairly flat-lying internal reflectors; and (2) postHorizon $\mathrm{A}^{\mathrm{u}}$ : usually exhibiting (from the base) chaotic sedimentary sequences, migrating sediment waves, and ponded turbidites (lower continental rise terrace only). The $\mathrm{J}_{1}$ reflector, seen to overlap a northwest-southeasttrending basement high just to the east of the site (Fig. 3 ), lay at an estimated sub-bottom depth of $1664 \mathrm{~m}$, and the basement lay at $1814 \mathrm{~m}$, or a total depth of $6430 \mathrm{~m}$ below sea level. Located in the "Jurassic magnetic quiet zone" about $80 \mathrm{~km}$ west of magnetic Anomaly 25, the basement at Site 603 has been estimated to be late Callovian in age by extrapolation of the magnetic anomaly pattern, using the scales of van Hinte (1976) or Cande et al. (1978). The more recent revisions to the time scale by Kent and Gradstein (1985) place M25 at the Oxfordian/
Kimmeridgian boundary, which would imply an early Oxfordian age for oceanic basement at this site.

At Site 603, Leg 93 cored three holes, recovering a record amount of sediment for any one DSDP site. ${ }^{3}$ Loss of the drill string (see Site 603 chapter for details) ended all attempts to reach Jurassic basement on this cruise. Subsequently DSDP Leg 95 returned to Site 603 in September, 1983, to drill three additional holes in a further unsuccessful attempt to reach deeper strata and to obtain geophysical logs for the stratigraphic section. The hole data and principal results for each of the holes attempted are given in Tables 1 and 2.

\section{Modified Cruise Plan}

With the loss of our capability for deep drilling at Site 603 , we received instructions relayed from the IPOD Planning Committee to proceed to the upper continental rise off New Jersey, where we were to core a site (designated, for planning purposes, NJ4) along the proposed New Jersey Transect, a series of holes along U.S.G.S. multichannel seismic reflection profile 25 that were designed to provide a cross-section of the upper Mesozoic-Cenozoic strata across this passive continental margin. The drilling prospectus for this site, which was provided by TELEX, is given in Figure 4. Two holes drilled at this locality (redesignated upon drilling as Site 604; see Fig. 1 for location) encountered unstable upper Miocene sands; both had to be abandoned shortly before reaching $300 \mathrm{~m}$ sub-bottom because of caving within the hole. A third hole, offset some $6 \mathrm{~km}$ further updip to avoid Miocene sands, was successfully cored at Site 605 into Upper Cretaceous limestone before being abandoned at $816.7 \mathrm{~m}$, when drilling time for the cruise expired after a 24-hr extension to reach the $\mathrm{K} / \mathrm{T}$ boundary. Hole data for these sites are given in Tables 1, 3, and 4 .

In general, sedimentation along the continental rise of the U.S. Atlantic margin has been strongly affected by both shallow and deep marine processes; thus its history is relatively complex. Until Deep Sea Drilling Project Leg 93, however, drill data along the rise of the U.S. Atlantic margin were limited compared to those of the continental shelf and the deeper, more seaward expanses of the North American Basin, particularly for pre-Neogene sediments. Past interpretations, therefore, have been strongly dependent on studies of seismic reflection profiles, such as those presented by Schlee et al. (1976), Tucholke and Mountain (1979), Klitgord and Grow (1980), Ewing and Rabinowitz (1984), and Hutchinson et al. (1983). It was to narrow this data gap that DSDP Leg 93 drilled a series of deep holes on both the lower and upper continental rise, a task which was continued by DSDP Leg 95. Our Leg 93 team results, which have been made available as expeditiously as possible (see Leg 93 Staff, 1983; Leg 93 Scientific Party/Leg 94 Scientific Party, 1984; von Rad et al., 1984; van Hinte et al., 1985a, b; Wise et al., 1986), have expanded our understanding of the geologic history and the processes which have shaped the North Atlantic continental rise.

\footnotetext{
${ }^{3}$ Four holes were attempted, but no penetration was achieved at Hole $603 \mathrm{~A}$ (see Table 1).
} 


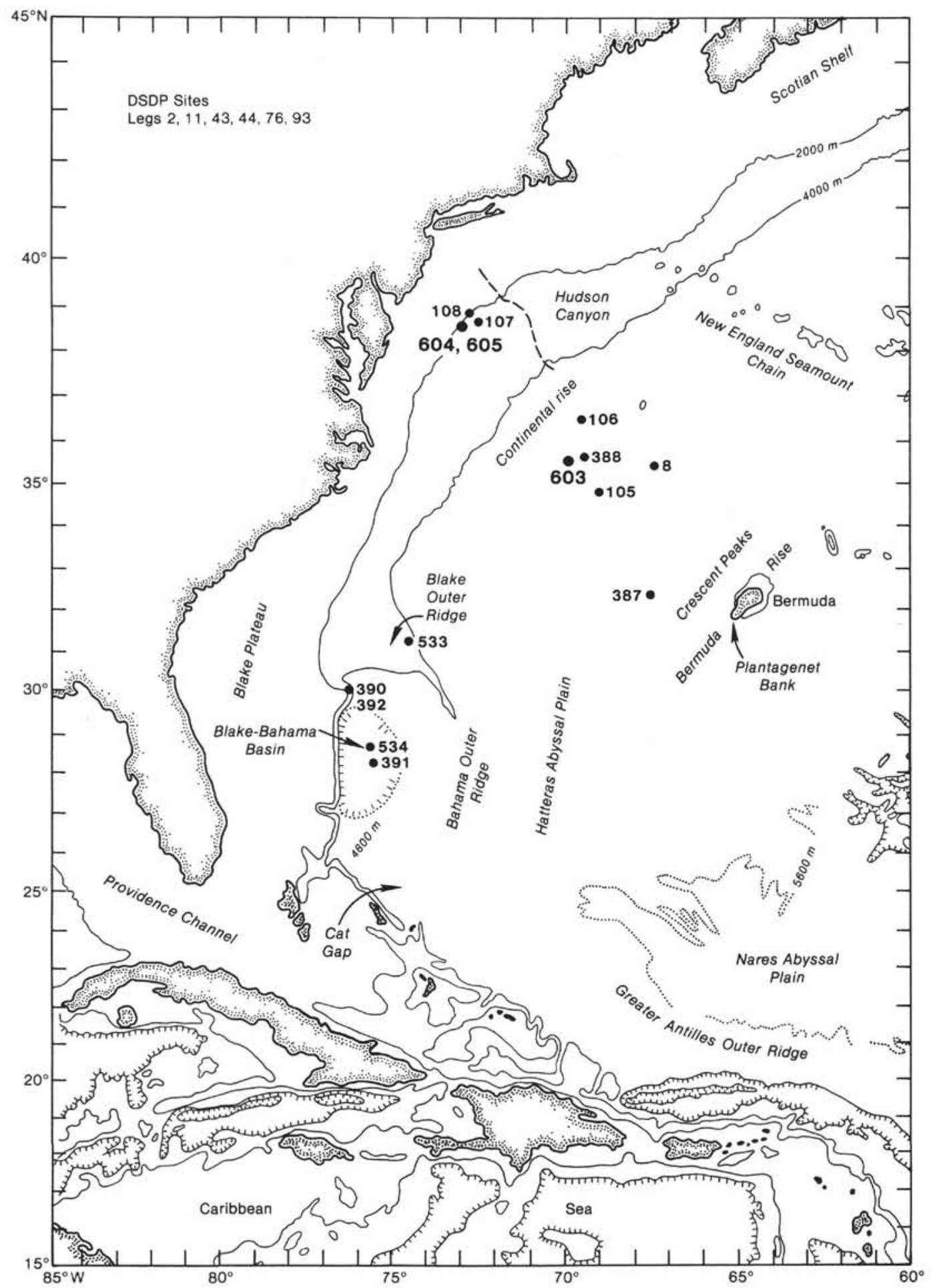

Figure 1. Location of DSDP Leg 93 Sites 603 to 605 and other nearby DSDP Sites off the U.S. Atlantic margin.

The main objective of this synopsis is to trace the history of sedimentation beneath the continental rise as revealed by our drill cores. In summarizing the many ship and shore laboratory studies embraced by this volume, we wish particularly to relate those observations which, taken together, help delineate major sedimentary sequences and events. Where opinions differ, we do not attempt to impose final answers or to arbitrate a consensus solu- tion. Instead, we view unresolved problems as a realistic consequence of the still limited nature of our data or of the time constraints placed by necessity on the reduction and analysis of that data. As such, we consider the unresolved questions raised by our investigations as the natural departure point for future studies of Leg 93 cores and for pursuing additional drilling objectives along this highly fascinating passive margin. 


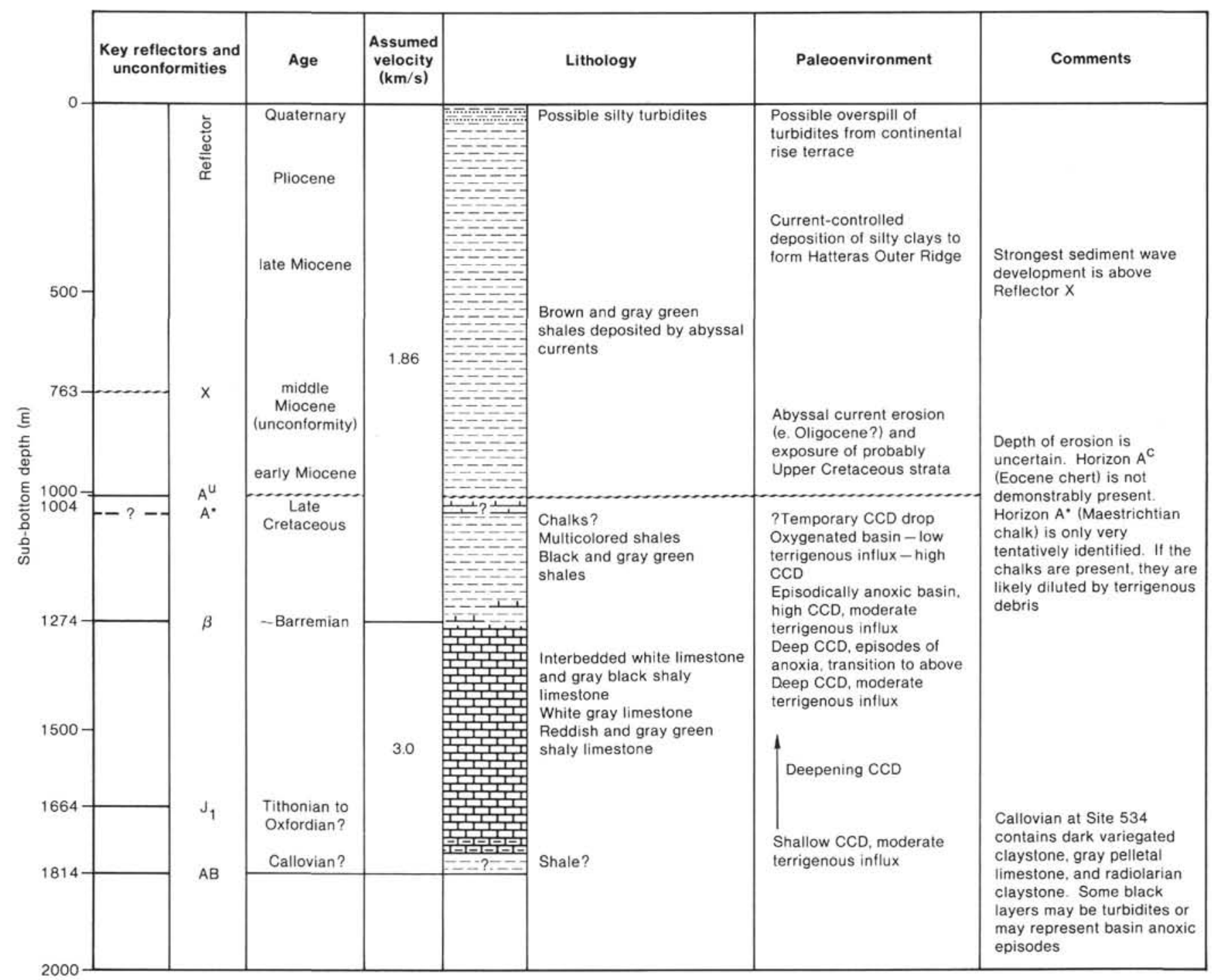

Figure 2. Expected stratigraphy at Site 603 (formerly designated in the prospectus ENA-3D). From Tucholke et al., 1982.

We wish to relate our drill sites to each other as well as to their regional setting. Therefore, we describe first the long $(1576 \mathrm{~m})$ section cored beneath the lower continental rise at Site 603 (Fig. 1), but concentrate primarily on the rather persistent Cretaceous turbidites recovered there. Next we discuss the Cretaceous/Tertiary boundary and Paleogene sections recovered on the upper rise at Site 605 before moving on to the upper Neogene debris flows encountered at nearby Site 604 . Last, we return to Site 603 to describe the largely coeval Neogene sediment drift that underlies the lower continental rise hills.

\section{SITE 603, LOWER CONTINENTAL RISE}

As stated previously, three holes were drilled at Site 603 . These were spudded in $4634-4639 \mathrm{~m}$ of water on the lower continental rise $270 \mathrm{n}$. mi. $(435 \mathrm{~km})$ east of Cape Hatteras, North Carolina (Fig. 1; Table 1). The principal scientific objectives were:
1. To sample and identify the several prominent "seismic reflectors" in the Mesozoic and Cenozoic sedimentary section (acoustic basement, $\mathrm{J}_{1}, \beta, \mathrm{A}^{*}, \mathrm{~A}^{\mathrm{u}}$, and $\mathrm{X}$ );

2 . To sample the upper sedimentary section by hydraulic piston corer (HPC) to understand active currentcontrolled depositional processes which predominated in the area during the late Cenozoic;

3. To sample the oldest sediments deposited on oceanic crust at a location landward of nearby DSDP Site 105 , where Upper Jurassic sediments had been cored over a prominent basement high.

\section{Stratigraphy}

The seismic sequences and lithologic units penetrated at Site 603 are depicted in Figures 5 and 6. Figure 7 provides a detailed view of the major lithologic components in the Cretaceous section. Despite facies differences arising from the influx of terrigenous sediments from the nearby continent, general correlations can be made be- 


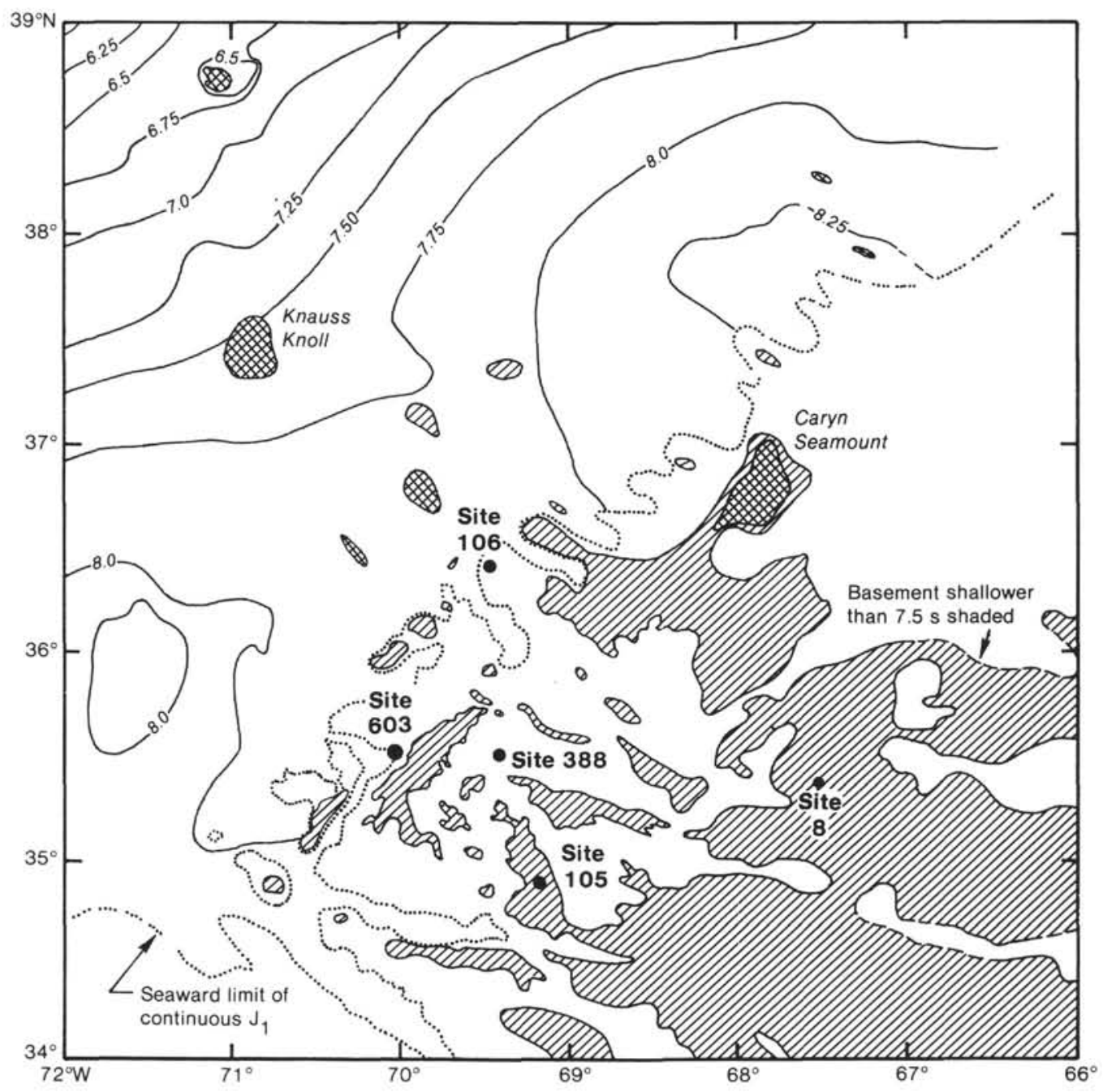

Figure 3. Location of Site 603 with respect to basement highs (hachured) and seaward limit of $\mathrm{J}_{1}$ reflector. Numbers indicate depths to Horizon $\mathrm{J}_{1}$ in seconds (two-way traveltime) below sea level. From Tucholke et al., 1982.

Table 1. Log 93 coring summary.

\begin{tabular}{|c|c|c|c|c|c|c|c|c|c|}
\hline Hole & Dates (1983) & $\begin{array}{l}\text { Latitude } \\
\text { (N) }\end{array}$ & $\begin{array}{l}\text { Longitude } \\
\text { (W) }\end{array}$ & $\begin{array}{l}\text { Water } \\
\text { deptha }\end{array}$ & $\begin{array}{l}\text { Penetration } \\
\text { (m) }\end{array}$ & $\begin{array}{l}\text { No. of } \\
\text { cores }\end{array}$ & $\begin{array}{l}\text { Meters } \\
\text { cored }\end{array}$ & $\begin{array}{l}\text { Meters } \\
\text { recovered }\end{array}$ & $\begin{array}{c}\text { Recovery } \\
(\%)\end{array}$ \\
\hline 603 & 5-11 May & $35^{\circ} 29.66^{\prime}$ & $70^{\circ} 01.70^{\prime}$ & 4634.00 & 832.6 & $41(13)$ & 393.0 & 226.38 & 58 \\
\hline $603 \mathrm{~A}$ & 11-12 May & $35^{\circ} 29.69^{\prime}$ & $70^{\circ} 01.69^{\prime}$ & 4633.00 & 0.0 & 0 & 0.0 & 0.00 & 0 \\
\hline $603 \mathrm{~B}$ & 12-31 May & $35^{\circ} 29.71^{\prime}$ & $70^{\circ} 01.71^{\prime}$ & 4633.00 & 1585.2 & $75(8)$ & 683.6 & 484.44 & 71 \\
\hline $603 \mathrm{C}$ & 31 May-6 June & $35^{\circ} 29.78^{\prime}$ & $70^{\circ} 01.86^{\prime}$ & 4639.50 & 366.0 & 40 & 366.0 & 314.44 & 86 \\
\hline 604 & 8-10 June & $38^{\circ} 42.79^{\prime}$ & $72^{\circ} 32.95^{\prime}$ & 2364.00 & 294.5 & 31 & 294.5 & 117.58 & 40 \\
\hline $604 \mathrm{~A}$ & 10 June & $38^{\circ} 43.08^{\prime}$ & $72^{\circ} 33.64^{\prime}$ & 2340.00 & 284.4 & $4(1)$ & 34.8 & 2.17 & 6 \\
\hline \multirow[t]{2}{*}{605} & 11-17 June & $38^{\circ} 44.53^{\prime}$ & $72^{\circ} 36.55^{\prime}$ & 2194.00 & 816.7 & $70(1)$ & 662.4 & 532.08 & 80 \\
\hline & & & & & & $261(23)$ & 2434.3 & 1677.09 & 69 \\
\hline
\end{tabular}

Note: The numbers inside parentheses are additional cores obtained from washed intervals.

a Water depth from sea level, as measured by drill string length.

tween the local lithologic units and the oceanic formations proposed for the North American Basin by Jansa et al. (1979) (see Fig. 6). Units IB to IVC are essentially devoid of calcareous material. In descending order, these units and their correlations are:

Unit I: $960 \mathrm{~m}$ of lower Pleistocene-lower/middle Miocene hemipelagic clay and claystone (Blake Ridge Formation). Unit I is subdivided on the basis of lithology and color into four subunits. The dark green homoge- nous muds of Subunit IA contain nannofossils and planktonic foraminifers deposited above the calcite compensation depth (CCD). Greenish gray muds of Subunits IB and IC are largely devoid of calcareous microfossils except for the more dissolution resistant discoasters. Subunit IC contains radiolarians in some numbers at selected intervals as well as the first unambiguous evidence of sporadic silt and sand turbidites below $720 \mathrm{~m}$ (Sample $603-44-2,64-65 \mathrm{~cm})$. In contrast to the green clays above, 
Table 2. Site 603 lithostratigraphy.

\begin{tabular}{|c|c|c|c|c|}
\hline Unit/Subunit & Lithology & Core level & $\begin{array}{l}\text { Sub-bottom } \\
\text { depth }(m)\end{array}$ & Age \\
\hline Unit I & Hemipelagic clay/claystone & $\begin{array}{l}603-1 \text { to } 603-54, C C \\
603 \mathrm{~B}-1 \mathrm{M} \text { to }-15-4,45 \mathrm{~cm} \\
603 \mathrm{C}-1 \text { to }-40, \mathrm{CC} \\
603 \mathrm{D}-1 \\
603 \mathrm{E}-1 \\
603 \mathrm{~F}-1 \mathrm{M} \text { to }-2 \mathrm{M}\end{array}$ & $\begin{array}{l}0-960.75 \\
(603 \mathrm{~B})\end{array}$ & Pleistocene-early Miocene \\
\hline Subunit IA & Nannofossil-bearing clay/claystone & $\begin{array}{l}603-1 \text { to } 603-19 \mathrm{M}, \mathrm{CC} \\
603 \mathrm{~B}-1 \mathrm{M} \text { to } 603 \mathrm{~B}-2 \mathrm{M}, \mathrm{CC} \\
603 \mathrm{C}-1 \text { to }-40, \mathrm{CC} \\
603 \mathrm{D}-1 \\
603 \mathrm{~F}-1 \mathrm{M}\end{array}$ & $\begin{array}{l}0-419.8 / 448.6 \\
(603)\end{array}$ & $\begin{array}{l}\text { early Pleistocene } \\
\text { Pliocene/late Miocene }\end{array}$ \\
\hline Subunit IB & Quartz-mica-bearing claystone & $\begin{array}{l}603-20 \text { to } 603-41, C C \\
603 \mathrm{~B}-3 \mathrm{M} \text { to } 603 \mathrm{~B}-4 \mathrm{M}-5 \\
603 \mathrm{~F}-2 \mathrm{M}\end{array}$ & $448.6-698.2(603)$ & late Miocene \\
\hline Subunit IC & $\begin{array}{l}\text { Biogenic-silica-bearing clay/claystone and } \\
\text { silt-bearing or silt-rich claystone }\end{array}$ & $\begin{array}{l}603-42 \text { to } 603-54, \mathrm{CC} \\
603 \mathrm{~B}-4 \mathrm{M}-5 \text { to } 14-3,65 \mathrm{~cm} \\
603 \mathrm{E}-1\end{array}$ & $698.2(603)-949.85(603 B)$ & $\begin{array}{l}\text { middle Miocene-early } \\
\text { Miocene }\end{array}$ \\
\hline Subunit ID & Silt-rich claystone & $\begin{array}{l}603 \mathrm{~B}-14-3,65 \mathrm{~cm} \text { to } \\
-15-4,45 \mathrm{~cm}\end{array}$ & $949.85-960.75^{\mathrm{a}}$ & early Miocene \\
\hline Unit II & Radiolarian claystone & $\begin{array}{l}603 \mathrm{~B}-15-445 \mathrm{~cm} \text { to } \\
-22-2,68 \mathrm{~cm} \\
603 \mathrm{~F}-3 \mathrm{M}\end{array}$ & $960.75-1022.78$ & $\begin{array}{l}\text { middle early Eocene } \\
\text { late Paleocene }\end{array}$ \\
\hline Unit III & Variegated claystone & $\begin{array}{c}603 \mathrm{~B}-22-2,68 \mathrm{~cm} \text { to } \\
-33-1,60 \mathrm{~cm}\end{array}$ & $1022.78-1119.1$ & Cenomanian-Coniacian \\
\hline Subunit IIIA & $\begin{array}{l}\text { Variegated claystone without carbona- } \\
\text { ceous claystone }\end{array}$ & $\begin{array}{l}603 \mathrm{~B}-22-2,68 \mathrm{~cm} \text { to } \\
-23, \mathrm{CC}\end{array}$ & $1022.78-1038.6$ & ? \\
\hline Subunit IIIB & $\begin{array}{l}\text { Variegated claystone (with greenish gray, } \\
\text { mostly reddish brown) and some } \\
\text { carbonaceous claystone }\end{array}$ & $603 \mathrm{~B}-24$ to $-29-2$ & $1038.6-1083.8$ & Santonian-Senonian \\
\hline Subunit IIIC & $\begin{array}{l}\text { Variegated claystone (with reddish } \\
\text { brown, greenish gray) and no carbo- } \\
\text { naceous claystone }\end{array}$ & $603 \mathrm{~B}-29-3$ to $-33-1,60 \mathrm{~cm}$ & $1083.8-1119.1$ & ? \\
\hline Unit IV & Black carbonaceous claystone & $\begin{array}{c}603 \mathrm{~B}-33-1,60 \mathrm{~cm} \text { to } \\
-44-1,32 \mathrm{~cm}\end{array}$ & $1119.1-1214.72$ & Turonian-Aptian \\
\hline Subunit IVA & $\begin{array}{l}\text { Black carbonaceous and pelagic greenish } \\
\text { gray claystone, lacking any reddish } \\
\text { brown color }\end{array}$ & $603 \mathrm{~B}-33-1,60 \mathrm{~cm}$ to $-38-2$ & $1119.1-1166.5$ & Turonian-Cenomanian \\
\hline Subunit IVB & $\begin{array}{l}\text { Less black carbonaceous, more pelagic } \\
\text { (greenish gray and reddish brown) } \\
\text { claystone }\end{array}$ & $603 \mathrm{~B}-38-3$ to $-41-4$ & $1166.5-1196.5$ & Cenomanian-Albian \\
\hline Subunit IVC & $\begin{array}{l}\text { Black carbonaceous and pelagic (greenish } \\
\text { gray only) claystone }\end{array}$ & $603 \mathrm{~B}-41-5$ to $-42, \mathrm{CC}$ & $1196.5-1204.8$ & Albian \\
\hline Subunit IVD & $\begin{array}{l}\text { Pelagic greenish gray, reddish brown with } \\
\text { less black carbonaceous claystone }\end{array}$ & $603 \mathrm{~B}-43-1$ to $-44-1,32 \mathrm{~cm}$ & $1204.8-1214.72$ & Aptian \\
\hline Unit $\mathrm{V}$ & $\begin{array}{l}\text { Interbedded laminated marl and biotur- } \\
\text { bated limestone with sandstone to } \\
\text { claystone turbidites }\end{array}$ & $\begin{array}{l}603 \mathrm{~B}-44-1,32 \mathrm{~cm} \text { to } \\
-82, \mathrm{CC} \\
603 \mathrm{E}-2 \mathrm{M} \text { to }-4 \mathrm{M} \\
603 \mathrm{~F}-4 \mathrm{M} \text { to }-9, \mathrm{CC}\end{array}$ & $1214.72-1576.2$ & Aptian-late Berriasian \\
\hline Subunit VA & As above with the turbidites & $\begin{array}{l}603 \mathrm{~B}-44-1,32 \mathrm{~cm} \text { to } \\
-76-1,120 \mathrm{~cm} \\
603 \mathrm{E}-2 \mathrm{M} \text { to }-4 \mathrm{M} \\
603 \mathrm{~F}-4 \mathrm{M} \text { to }-5 \mathrm{M}\end{array}$ & $1214.7-1512.3$ & Aptian-Valanginian \\
\hline Subunit VB & As above without the turbidites & $\begin{array}{l}603 \mathrm{~B}-76-1,120 \mathrm{~cm} \text { to } \\
-82, \mathrm{CC} \\
603 \mathrm{~F}-6 \text { to }-9, \mathrm{CC}\end{array}$ & $1512.3-1576.2$ & Valanginian-late Berriasian \\
\hline
\end{tabular}

a All sub-bottom depths hereafter are from Hole 603B.

Subunit ID is composed of yellowish brown to brown clays (Frontispiece, Fig. A), barren of microfossils except for fish teeth, which Hart and Mountain (this volume) found to be at least middle Miocene in age in Hole 603B, and early Miocene in age in Hole 603E (drilled by DSDP Leg 95).

Unit II: 63 m of variegated lower Eocene and upper Paleocene radiolarian claystone (Bermuda Rise Formation). This unit is extremely colorful at the top, with hues ranging from pale green, grayish green, reddish brown, and yellow brown, to pale orange. A particularly vivid sequence was christened the "Halloween Core" by our shipboard sedimentologists (Frontispiece, Fig. B). Radiolarian content varies from $50 \%$ to less than $10 \%$.
Incipient diagenesis has converted some of the biogenic opal to opal-CT, but not in quantities exceeding $50 \%$ of the rock; therefore the sediment is not a porcellanitic "chert" in the strict sense. A lithium spike noted in interstitial water samples (Site 603 chapter, this volume) may be due to the dissolution and reprecipitation of biogenic opal (Gieskes et al., 1982).

Unit III: 97 m of mostly Senonian (and lowest Paleocene?) variegated claystone (Plantagenet Formation). This unit is subdivided into three subunits based on the presence or absence of dark gray carbonaceous claystone. These organic-matter-rich clays were first drilled in Subunit IIIB (Santonian) and were subsequently encountered in each of the underlying lithologic units (Units IV and 
DEPOSITIONAL ENVIRONMENTS ON THE CONTINENTAL RISE: LEG 93 SUMMARY

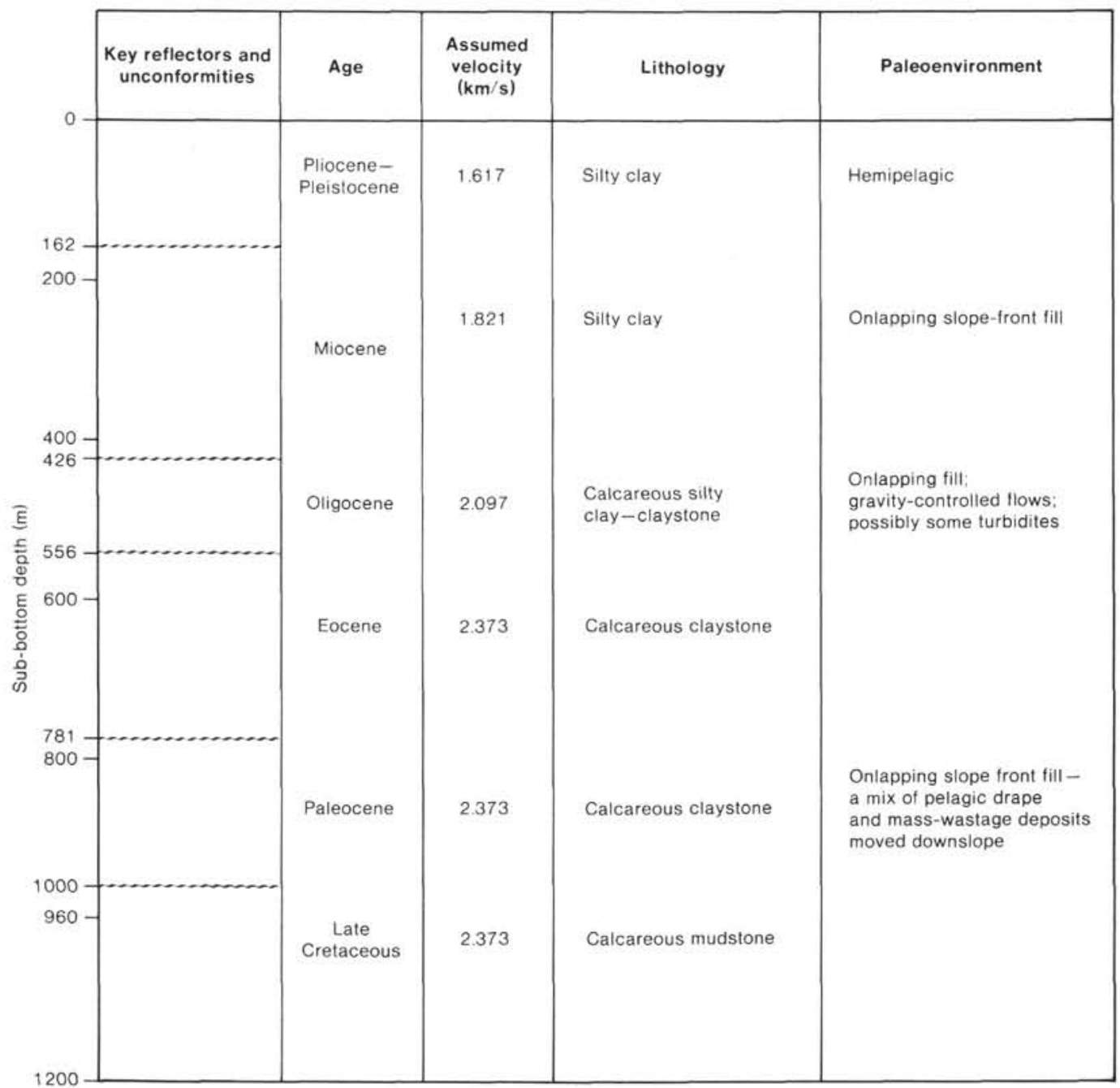

Figure 4. Expected stratigraphy at Site 604 (formerly designated NJ-4). From TELEX message received aboard ship, based on Schlee and Grow, 1980.

Table 3. Site 604 lithostratigraphy.

\begin{tabular}{|c|c|c|c|c|}
\hline Unit/Subunit & Lithology & Core-Section & $\begin{array}{l}\text { Sub-bottom } \\
\text { depth } \\
\text { (m) }\end{array}$ & Age \\
\hline I & $\begin{array}{l}\text { Gray to dark greenish gray alternations } \\
\text { of clay and silt }\end{array}$ & $\begin{array}{l}604-1 \text { to } \\
604-10-1,7 \mathrm{~cm}\end{array}$ & $0.0-84.0$ & late Pleistocene \\
\hline IA & Interbedded clay and silt layers & $604-1$ to $604-5,0 \mathrm{~cm}$ & $0.0-35.3$ & late Pleistocene \\
\hline IB & $\begin{array}{l}\text { Gray and dark greenish gray clay and silt } \\
\text { with slump structures }\end{array}$ & $\begin{array}{l}604-5,0 \mathrm{~cm} \text { to } \\
604-10-1,7 \mathrm{~cm}\end{array}$ & $35.3-84.0$ & late Pleistocene \\
\hline II & $\begin{array}{l}\text { Greenish gray clay with glauconite-rich } \\
\text { intervals (variable amounts of } \\
\text { biogenic silica) }\end{array}$ & $\begin{array}{l}604-10,7 \mathrm{~cm} \text { to } \\
604-26-2,46 \mathrm{~cm}\end{array}$ & $84.0-238.9$ & $\begin{array}{l}\text { Pleistocene } \\
\text { late Miocene }\end{array}$ \\
\hline IIA & $\begin{array}{l}\text { Greenish gray clay with glauconite-rich } \\
\text { sand and biogenic silica }\end{array}$ & $\begin{array}{c}604-10-1,7 \mathrm{~cm} \\
\text { through } \\
604-13, \mathrm{CC}\end{array}$ & $84.0-121.7$ & Pleistocene \\
\hline IIB & $\begin{array}{l}\text { Greenish gray clay with glauconite-rich } \\
\text { sand }\end{array}$ & $\begin{array}{l}604-14 \text { through } \\
604-19, C C\end{array}$ & $121.7-179.3$ & $\begin{array}{l}\text { Pleistocene-late } \\
\text { Pliocene }\end{array}$ \\
\hline IIC & Greenish gray clay with biogenic silica & $\begin{array}{l}604-20 \text { through } \\
604-24, C C\end{array}$ & $179.3-227.3$ & $\begin{array}{l}\text { Pliocene-late } \\
\quad \text { Miocene(?) }\end{array}$ \\
\hline IID & $\begin{array}{l}\text { Greenish gray clay with glauconite-rich } \\
\text { sand and biogenic silica }\end{array}$ & $\begin{array}{l}604-25 \text { through } \\
604-26-2,46 \mathrm{~cm}\end{array}$ & $227.3-238.9$ & late Miocene \\
\hline III & $\begin{array}{l}\text { Glauconite- and biogenic-silica-rich silty } \\
\text { claystone and conglomerates }\end{array}$ & $\begin{array}{l}604-26-2,46 \mathrm{~cm} \text { to } \\
604-31 \text { and } \\
604 \mathrm{~A}-2 \text { through } \\
604-4, C \mathrm{C}\end{array}$ & $238.9-294.5$ & late Miocene \\
\hline
\end{tabular}


Table 4. Site 605 lithostratigraphy.

\begin{tabular}{|c|c|c|c|c|}
\hline Unit/Subunit & Lithology & Core/Section & $\begin{array}{l}\text { Sub-bottom } \\
\text { depth } \\
\text { (m) }\end{array}$ & Age \\
\hline \multicolumn{5}{|l|}{ I } \\
\hline IA & $\begin{array}{l}\text { Gray silt-rich clay and green biogenic- } \\
\text { silica-bearing, calcareous-material- } \\
\text { rich clay }\end{array}$ & $\begin{array}{l}605-1 \text { to } \\
605-6-4,125 \mathrm{~cm}\end{array}$ & $0-198.5$ & Pleistocene \\
\hline IB & $\begin{array}{l}\text { Green biogenic-silica-bearing calcareous- } \\
\text { material-rich clay }\end{array}$ & $605-6-4,125-149 \mathrm{~cm}$ & $198.50-198.7$ & Pleistocene \\
\hline II & $\begin{array}{l}\text { Greenish gray biogenic-silica-rich nanno- } \\
\text { fossil chalk }\end{array}$ & $\begin{array}{l}605-6-4,149 \mathrm{~cm} \text { to } \\
605-22-3,50 \mathrm{~cm}\end{array}$ & $198.7-349.8$ & middle Eocene \\
\hline III & $\begin{array}{l}\text { Greenish gray nannofossil limestone with } \\
\text { varying amounts of foraminiferids } \\
\text { and calcified radiolarians }\end{array}$ & $\begin{array}{l}605-22-3,50 \mathrm{~cm} \text { to } \\
605-44-5,33 \mathrm{~cm}\end{array}$ & $349.8-563.8$ & $\begin{array}{l}\text { early middle Eocene } \\
\text { to early Eocene }\end{array}$ \\
\hline IV & $\begin{array}{l}\text { Dark greenish gray clay-rich to clayey } \\
\text { nannofossil limestone (marl) }\end{array}$ & $\begin{array}{l}605-44-5,33 \mathrm{~cm} \text { to } \\
605-64-1,54 \mathrm{~cm}\end{array}$ & $563.8-740.4$ & late Paleocene \\
\hline $\mathrm{v}$ & $\begin{array}{l}\text { Olive gray, silt-rich or foraminifer-rich, } \\
\text { clayey nannofossil limestone }\end{array}$ & $\begin{array}{l}605-64-1,54 \mathrm{~cm} \\
\text { through } \\
605-71, \mathrm{CC}\end{array}$ & $740.4-816.7$ & $\begin{array}{l}\text { early Paleocene } \\
\text { to late } \\
\text { Maestrichtian }\end{array}$ \\
\hline VA & $\begin{array}{l}\text { Dark greenish gray, glauconite-bearing } \\
\text { and silt-rich nannofossil clayey } \\
\text { limestone }\end{array}$ & $\begin{array}{l}605-64-1,54 \mathrm{~cm} \text { to } \\
605-66-1,120 \mathrm{~cm}\end{array}$ & $740.4-760.2$ & early Paleocene \\
\hline VB & $\begin{array}{l}\text { Olive gray, clay-rich foraminifer-nanno- } \\
\text { fossil limestone }\end{array}$ & $\begin{array}{l}605-66-1,120 \mathrm{~cm} \text { to } \\
605-71, \mathrm{CC}\end{array}$ & $760.2-816.7$ & late Maestrichtian \\
\hline
\end{tabular}

V) as well. Carbonaceous claystones are not present in sediments from Subunits IIIA or IIIC. Nearly all cores of Unit III contain 1-10\% terrigenous silt and sand. Considered turbiditic in origin, these are also found in all underlying lithologic units. This comparatively landward locality, however, is the only DSDP site in which terrigenous clastics have been reported from the Plantagenet Formation.

Near the top of Unit III in Sample 603B-22-3, $73 \mathrm{~cm}$ $(1023.3 \mathrm{~m})$ is a $4.5-\mathrm{cm}$-thick, current-bedded sandy layer (Fig. 8A) which contains numerous dark green spherules, each about $1 \mathrm{~mm}$ in diameter. One of us (JEVH) immediately suspected aboard ship that this spectacular bed marks the Cretaceous/Tertiary boundary impact event (Alvarez et al., 1980; Smit and Hertogen, 1980), a supposition which apears to have been borne out by the shore-based study of Klaver et al. (this volume; see discussion under "Cretaceous Depositional History"), which showed elevated concentrations of $\mathrm{Co}$, $\mathrm{As}$, and $\mathrm{Ni}$ in these smectite spherules. (Unfortunately, equipment limitations precluded analysis of the iridium levels of these spherules.)

Unit IV: $96 \mathrm{~m}$ of mid-Cretaceous (Aptian-Turonian) black carbonaceous claystones (Hatteras Formation). This unit is subdivided by the occurrence or relative abundance of pelagic reddish brown claystones which are present in Subunits IVB and IVD. It contains the highest concentration of "black shales" (carbonaceous claystones) in the section. Wood fragments (charcoal) are common. Organic carbon contents range up to $20.4 \%$ (Herbin et al., this volume). The organic geochemistry of cores from this and the other Cretaceous units is discussed in detail in this volume by a wide variety of investigators (see Part VI: Organic Geochemistry, and the synthesis by Meyers, this volume). Sharp basal contacts and graded silts at the bases of the black claystones suggest that they were emplaced as mud turbidites. Occasional welldefined silt turbidites (Bouma subdivision $\mathrm{T}_{\mathrm{c}}$ ) are also present (Fig. 8B).
Unit V: $361 \mathrm{~m}$ of upper Berriasian-lower Aptian interbedded nannofossil clays and limestones with sandstone to claystone turbidites (Blake-Bahama Formation of Jansa et al., 1979, plus an unnamed sand unit at the top of the sequence). This unit is distinguished from Unit IV by the presence of abundant calcareous nannofossils. It is subdivided into two subunits based on the presence or absence of turbidites. Subunit VA includes $30 \mathrm{~m}$ of unconsolidated coarse sand at the top and is further characterized by abundant claystone, siltstone, and sandstone turbidites and debris flows (Fig. 8C, and Frontispiece, Fig. C). These turbidites are of two main types: siltstonesandstone and organic-matter-rich claystone. The presence of intermediate types and complete sandstone to claystone graded sequences indicates that the two textural types are related. Subunit VB is composed of in situ pelagic carbonates which consist of rhythmic alternations of laminated and bioturbated nannofossil chalks and limestones. These lithologies also occur in Unit VA (Fig. 7B).

\section{Cretaceous Depositional History}

\section{Blake-Bahama Limestone Facies}

The oldest sediments (late Berriasian in age) recovered at Site 603 are characterized by carbonate cycles consisting of laminated marls that alternate with bioturbated homogeneous limestones. Predominantly pelagic, these may represent alternating periods of aerobic and dysaerobic bottom conditions, respectively, perhaps caused by periodic changes in the intensity of ocean circulation, upwelling and oxygen replenishment in the somewhat narrow, restricted, incipient North Atlantic ocean basin. Such oscillations could be caused by variations in the earth's orbital parameters to produce Milankovitchlike cycles (Ogg et al., this volume). On the other hand, lower carbonate contents, higher concentrations of clay minerals, terrestrial silts, and organic matter, and the general lack of bioturbation in the laminated intervals 

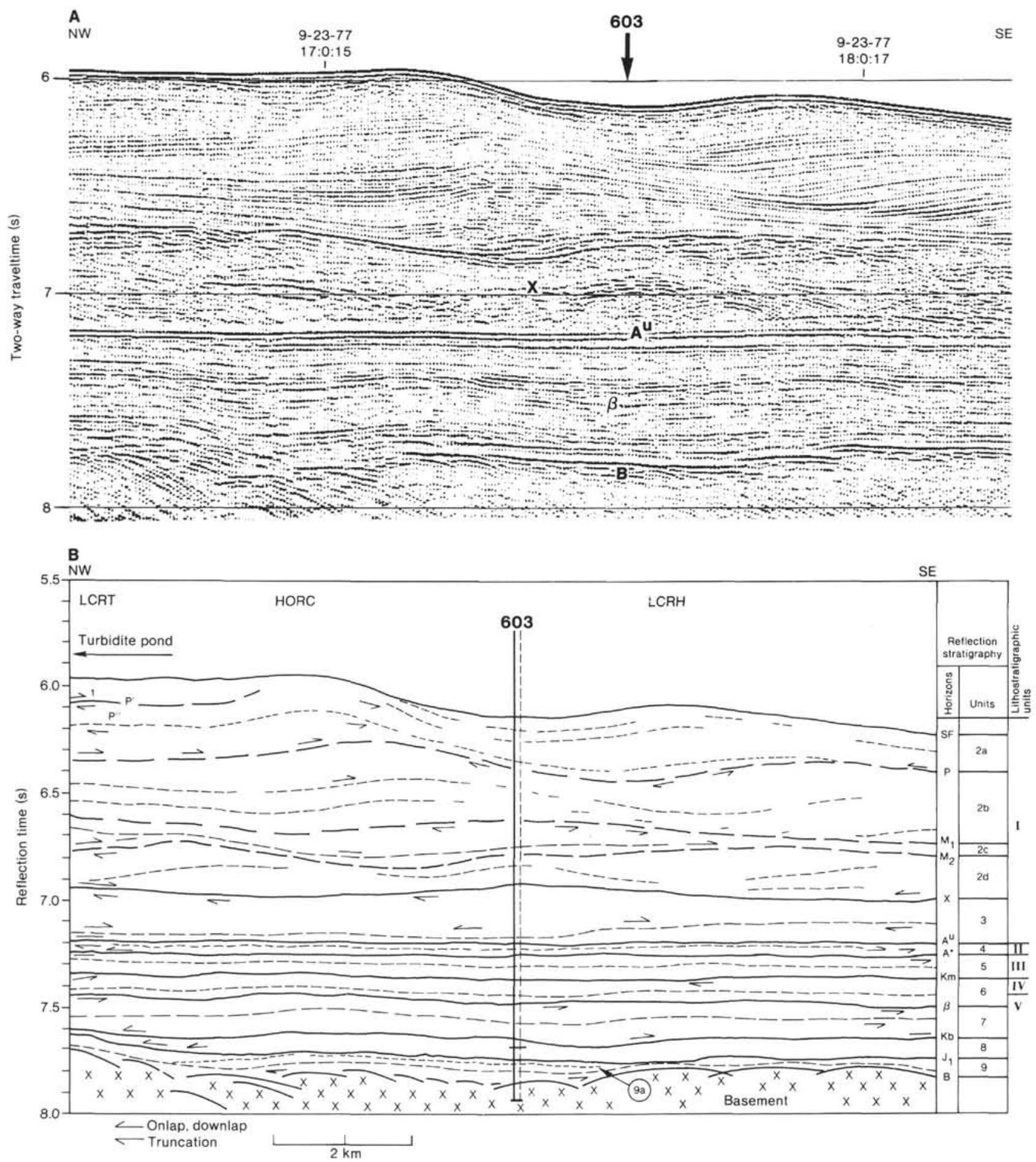

Figure 5. Original profile (A) and line drawing (B) after multichannel seismic reflection profile Conrad 2101-77. Units I to V are local lithostratigraphic units. Units 1 to 10 are local seismostratigraphic units; Units 1 (turbidite pond to the west) and 9 (the Jurassic) were not drilled during Leg 93. Seismic reflection horizons (sequence boundaries) are shown on the right. LCRT = lower continental rise terrace. HORC $=$ Hatteras Outer Ridge Crest. LCRH = lower continental rise hills.

suggest that these could represent extreme distal turbidites (entrained by and deposited from nepheloid suspensions) in quantities sufficient to rapidly bury benthic dwelling organisms (Haggerty, this volume). Supporting this argument is the fact that the laminated intervals appear in the North American Basin during the Berriasian (Jansa et al., 1979), about the time that extensive Neo- comian "Wealden-type" deltas begin to develop along the fringes of this seaway (Emery and Uchupi, 1984). Alternatively, the laminated intervals may represent deposits from nepheloid suspensions generated by contour currents (Dean and Arthur, this volume).

The limestone sequence is first interrupted in the upper Valanginian by organic-rich claystone turbidites, the 


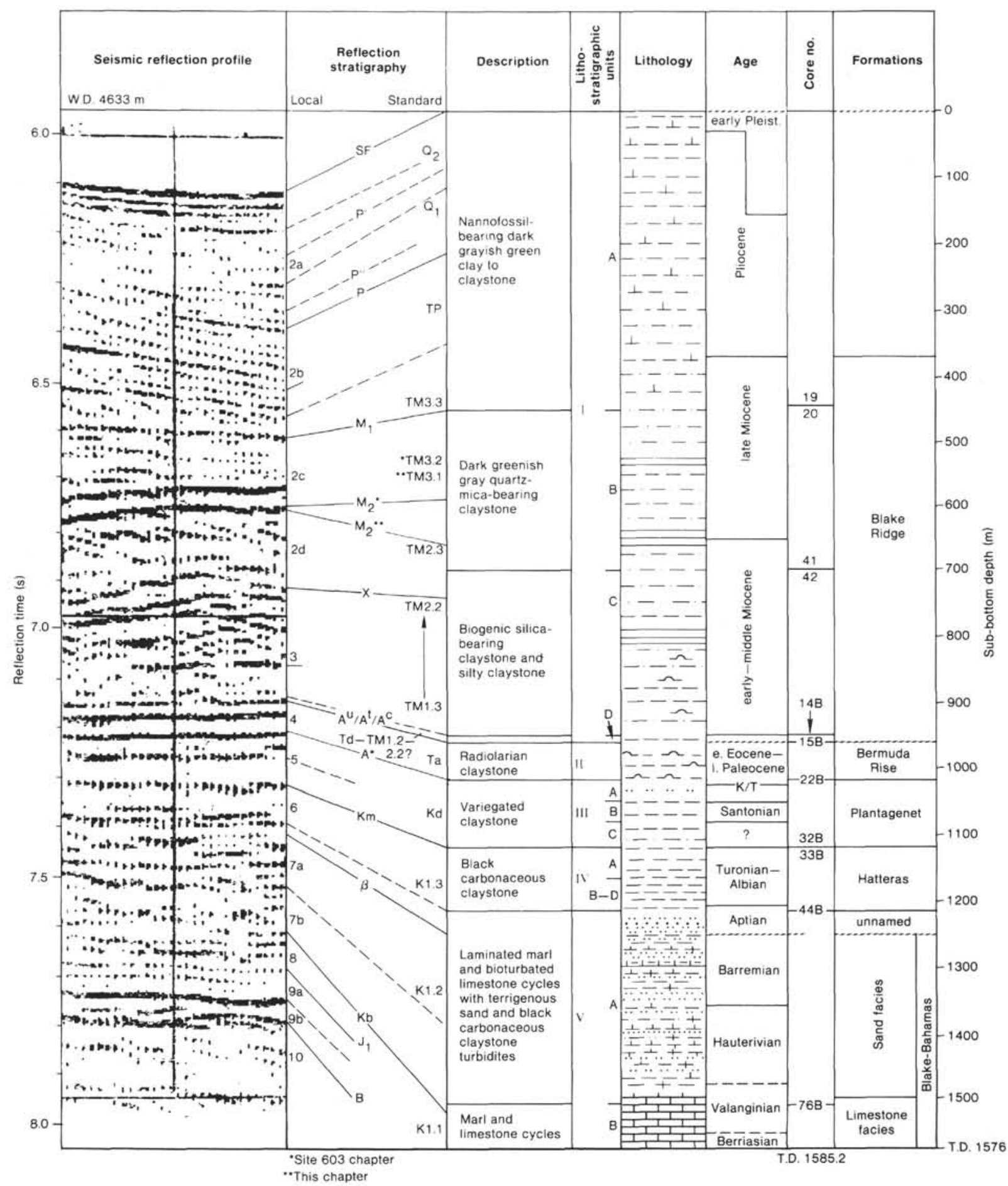

Figure 6. Stratigraphic summary of Site 603 (Holes 603 to 603C). Local lithostratigraphic and seismostratigraphic units numbered as in Figure 5; standard seismic sequence notation after Vail et al. (1980). Reflection Horizon $\mathrm{M}_{2}{ }^{* *}$ represents alternate correlation proposed by Muza et al. (this volume). Lithology symbols are explained in the Explanatory Notes to this volume.

first clear-cut indication of downslope depositional processes in the section drilled. The turbidites contain exceptionally well preserved calcareous nannofossils which must have been derived from the slope or upper rise where deposition could have been taking place within a broad oxygen minimum zone. Whole ammonites (Frontispiece, Fig. D) and aptychi from unsplit cores provide addition- al biostratigraphic control for this part of the section, although it is of lesser quality than the age control provided by palynology and nannofossil biostratigraphy. One specimen collected aboard ship and originally thought to be an aptychus has since been found to be the lower jaw of a marine vertebrate (Hoedemaker, this volume), the first such jaw recovered by deep-sea drilling. 

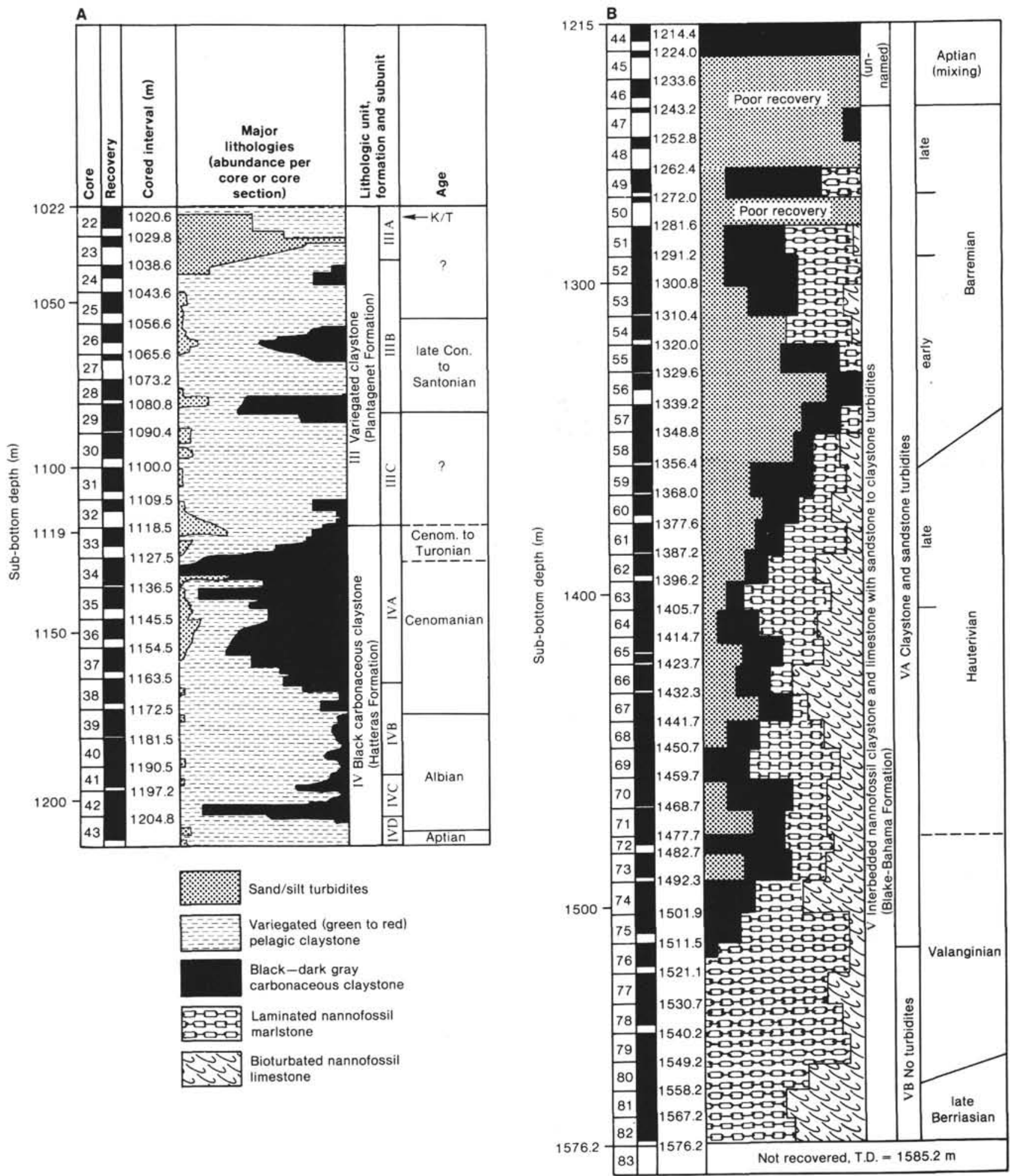

Figure 7. Lithologies, lithologic units, oceanic formations, and ages for the Cretaceous section cored in Hole $603 \mathrm{~B}$. A. Cores 22 to 43 (lithologic Units III and IV). B. Cores 44 to 83 (lithologic Unit V).

\section{Cape Hatteras Deep-Sea Fan Complex}

Silt and sandstone turbidites first appear in the uppermost Valanginian, reach a peak in the lower Barremian and, following an erosive, massive sand-depositional event in the early Aptian, continue intermittently into the Senonian of Unit III (Fig. 7). Over a 218-m interval in Subunit VA, the turbidites comprise about $47 \%$ of the recovered section. Largely unconsolidated medium-grained terrigenous sands with shallow-water shell fragments (disturbed by drilling) constitute nearly all of the sediment recovered from the lower Aptian Cores 603B- 
A

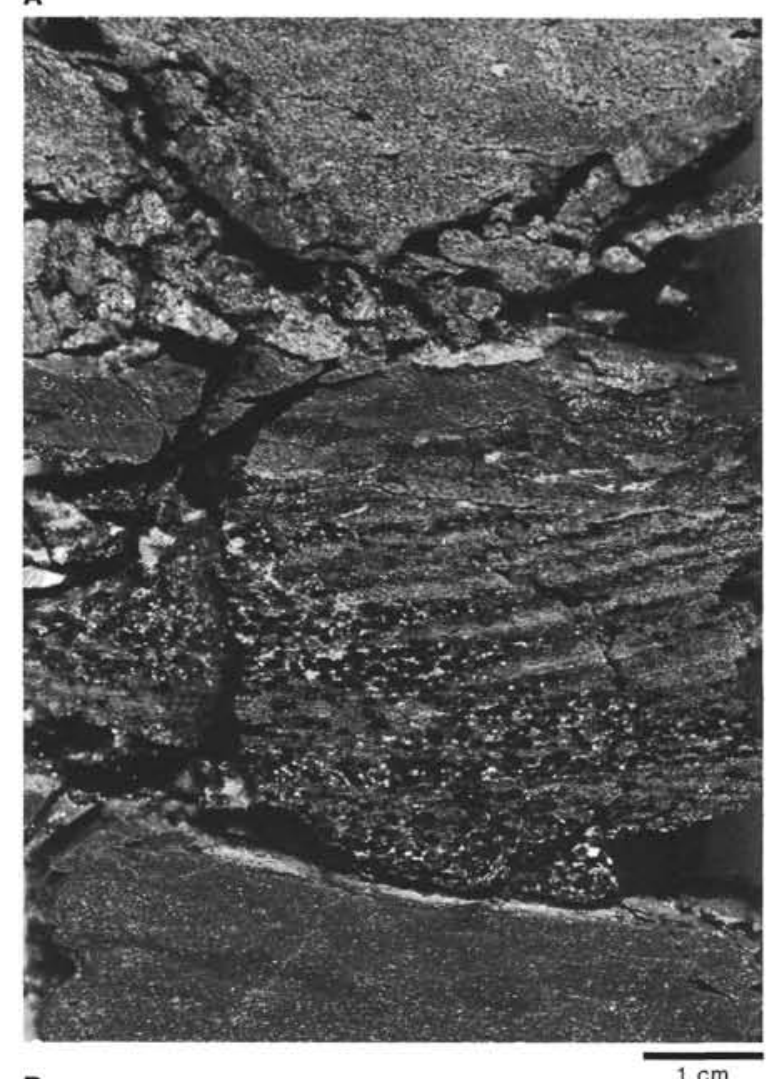

B

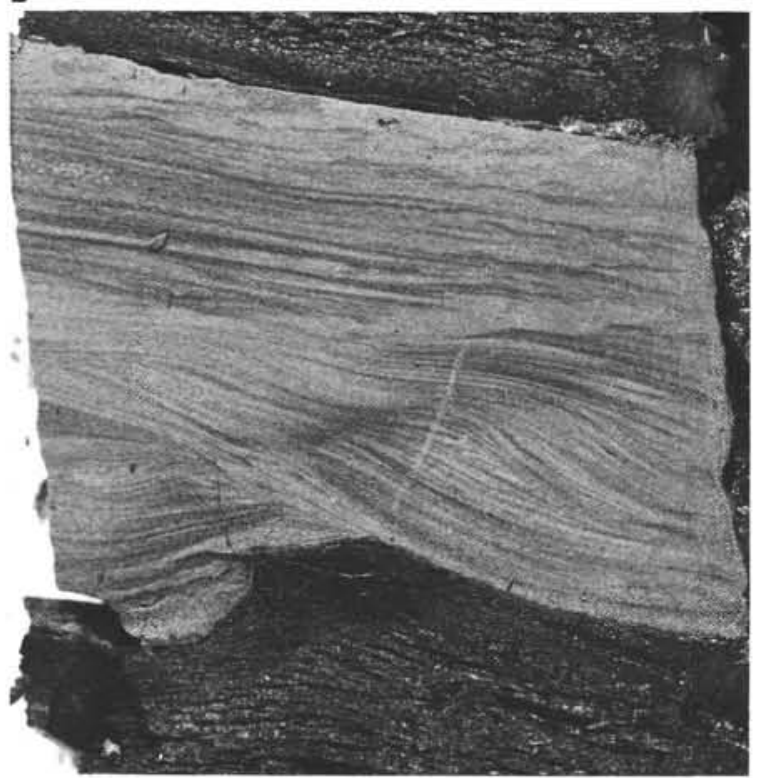

c

${ }^{0}$

58-1

58-2

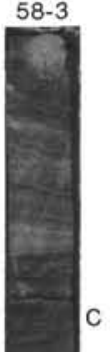

58-4

58-5 D
$\mathrm{C}=\mathrm{C}$
$\mathrm{C}$
$\mathrm{C}$
$\mathrm{C}$
$\mathrm{C}$
$\mathrm{C}$

20

30

40

50

60

70

E

70

80

90

100

110

120

130

${ }_{150}^{140}$ 
45 and -46 . Below upper Barremian Core 603B-48, individual turbidites range up to $2 \mathrm{~m}$ in thickness and are dominated by subangular quartz with abundant feldspar, mica, heavy minerals, opaques, wood fragments (locally up to $20 \%$ ), glauconite, and shallow-water bioclastics. Classified as arkoses and subarkoses (Prezbindowski and Pittman, this volume), the sands may be tightly cemented by ferroan calcite at the base of some beds, from upward migration of calcite cements derived from marls and carbonate-rich sediments below the sandy units (example, Fig. 8C, whitish sandstone at 603B-58-1, $65 \mathrm{~cm}$ ). Otherwise the sands are usually embedded in an argillaceous matrix and can normally be split by the pressure of a fingernail.

Collectively, the siliciclastic turbidites exhibit the entire range of Bouma structures; however, the basal sequences $\left(\mathrm{T}_{a}\right.$ to $\left.\mathrm{T}_{c}\right)$ are dominant, and in general the turbidites are disorganized and characterized by incomplete Bouma sequences. Associated with these are intraclastrich debris flows and plastically deformed and microfractured blocks of fine-grained sediments up to $30 \mathrm{~cm}$ across (see Fig. 9). These distorted blocks could denote slumped overbank deposits, which in turn would indicate the presence of well-defined fan channels. As noted by Wise et al. (1986), similar features were found to be characteristic of cores taken at overbank Sites 617 and 620 in the middle Mississippi fan, where high sedimentation rates promoted locally unstable slopes (Coleman et al., 1985).

A detailed analysis of these turbidites is given by Sarti and von Rad (this volume), who present a channellevee model for the deposition of the Hauterivian-Barremian turbidites at Site 603 (Fig. 10). By this model, the turbidity currents would have largely bypassed the drill site, discharging the bulk of their loads seaward of Site 603. Channel migration that occasionally breached the levee system would account for some of the mudstone rip-up clasts commonly observed in the turbidites at this site. The channel-levee structures would also account for the "hummocky" seismic reflection pattern that characterizes seismic reflection Unit 7, which encompasses the clastic sequence (Figs. 5 and 6). Apparently Hole 603B intersected a complex of one or more deep-sea fans which perhaps form part of an apron of clastic-rich sediments of this age along the continental margin of eastern North America.

Fan deposition culminated with the emplacement of the lower Aptian loose sands recovered in Cores 603B-45 and -46 . These are the coarsest in the section, and the emplacement of most of this material must have been a nearly instantaneous geologic event. Presumably there was insufficient carbonate incorporated along with this material to permit subsequent cementation-hence the unconsolidated nature of the sediment. If, as in Figure 11 , we consider the short sediment section of consolidated sandstones recovered in Core 603B- 47 to have been drilled at the bottom of the 9.6-m cored interval (not, as represented arbitrarily by DSDP convention, at the top of the interval as in Fig. 7B), then the total interval of loose sand would equal approximately $30 \mathrm{~m}$. As shown in Figure 11, our drilling rate log suports this supposi-

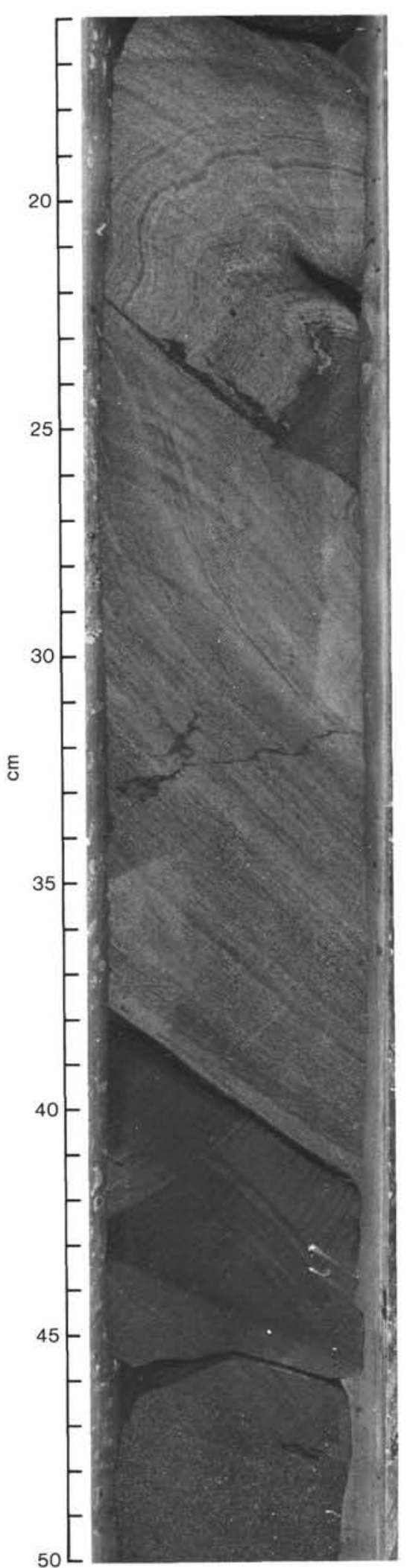

Figure 9. Slump fold in laminated nannofossil claystone, black claystone, and sandstone of Unit VA (Blake-Bahama Formation, Core 603B-58-1, 16-50 cm, Barremian). This features may be associated with slumped overbank deposits similar to those cored recently on the Mississippi fan (Leg 96 Scientific Party, 1984; Coleman et al., 1985). 


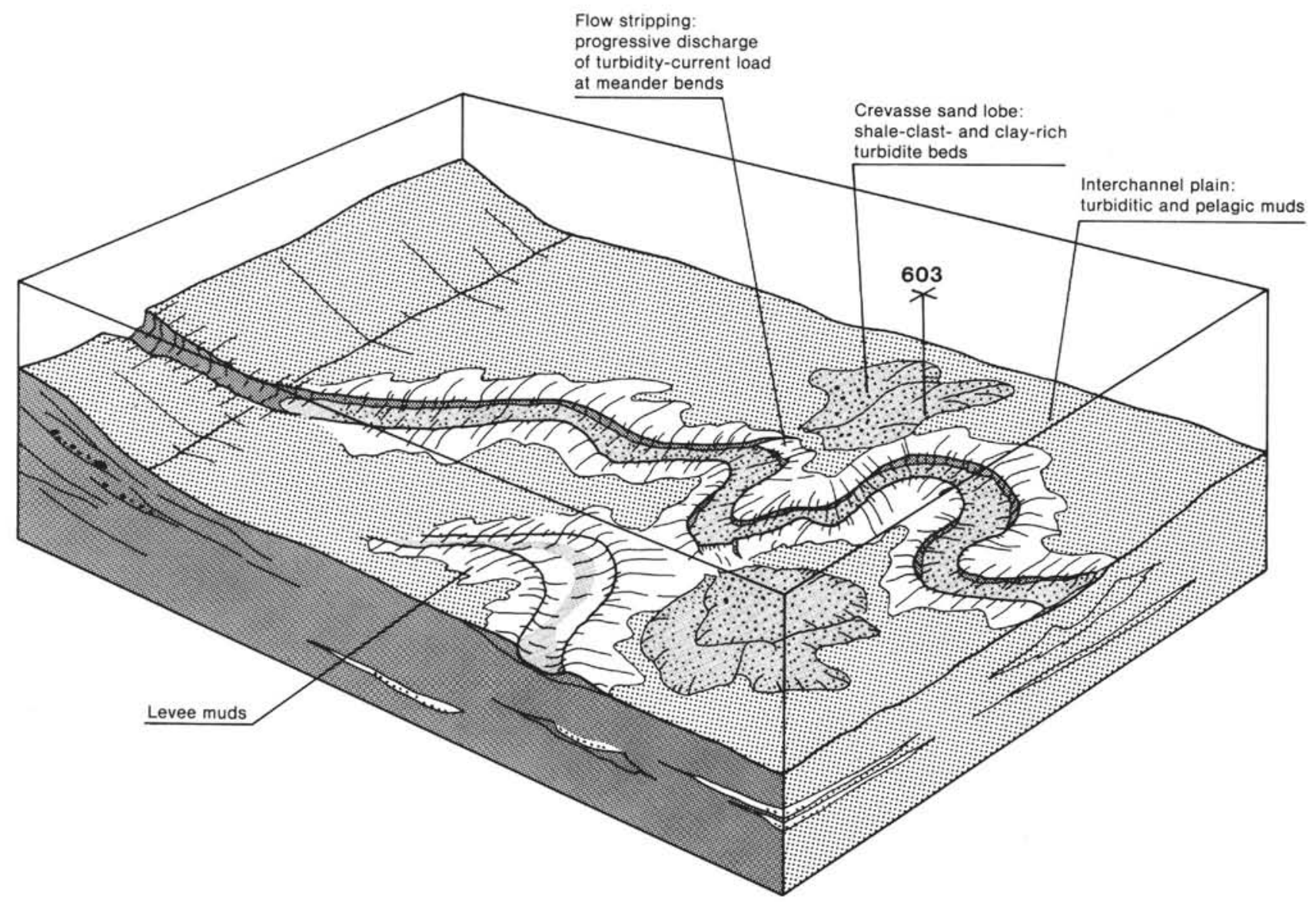

Figure 10. Idealized diagram showing a postulated channelized mid-fan setting for Site 603 developed during the deposition of the lower turbiditic sequence (Cores 603B-76 to -49). Crevasse sand lobes rich in clay and replete with shale clasts form at meander bends where channel migrations cause breaks in the levee (from Sarti and von Rad, Fig. 7, this volume).

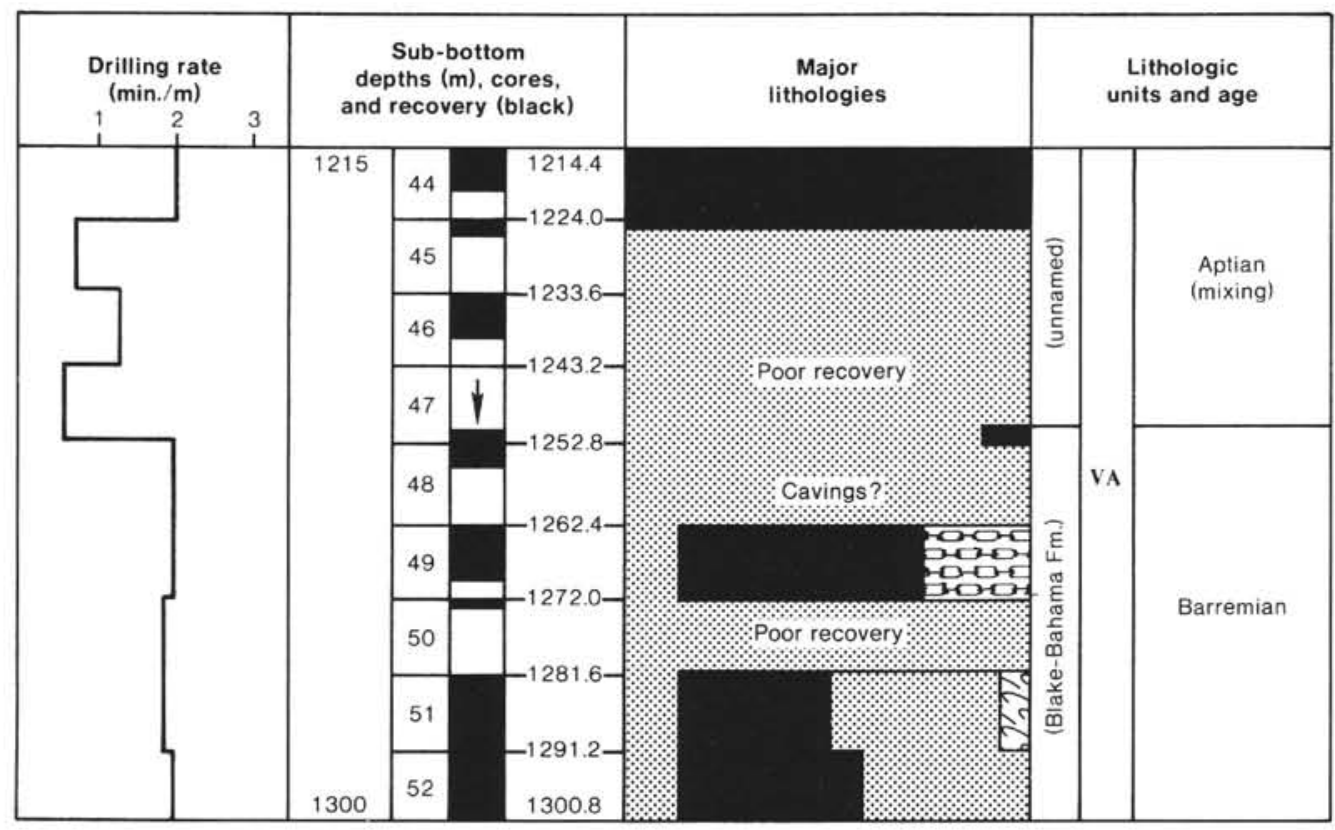

Figure 11. Reinterpretation of the upper portion of Figure 7B to show probable extent of the massive, unconsolidated 30-m lower Aptian sand unit near the top of lithologic Unit VA. The recovered portion of Core 603B47 has been moved to the bottom of the cored interval (arrow) rather than to the top as in Figure 7B, thereby allowing better correlation of the unconsolidated sand unit with the drilling rate log (left). Lithology symbols as in Figure 7. 
tion (about $1 \mathrm{~min} . / \mathrm{m}$ for Cores 603B-45 through -47 , versus 2 or more $\mathrm{min} . / \mathrm{m}$ for the more consolidated section above and below). The drilling rate also suggests that the soft, coarse sand recovered in Core 48 and at the top of Core 49 could be downhole cavings.

The recovery in Cores 603B-45 through -49 was generally poor, so other interpretations can be advanced regarding the origin or emplacement of the unconsolidated sands. Prezbindowski and Pittman (this volume) make the novel suggestion that the sands may originally have been cemented to some degree by ferroan calcite and that the present porosity of the loose sands down through Core 48 may be in part secondary, created by the "focused flow" of corrosive late-stage, channelized, compactional fluids moving beneath the barrier of impermeable silts and clays that overlie the sands (Cores 44 and above). Another way to view these sands is to consider the entire sand-rich sequence (Cores 45 to 49 ) as a genetic unit (Sarti and von Rad, this volume). These authors assume for this interval an overall minimum sedimentation rate of $100 \mathrm{~m} / \mathrm{m}$.y. (based on that of "most modern and ancient outer fans"), and thereby speculate that its deposition took less than $1 \mathrm{~m}$.y. This interpretation requires that the dinoflagellate chronostratigraphic boundary between Cores 46 and 47 be disregarded.

As noted by Wise et al. (1986), paleontologic dating of the sands at the top of Subunit VA initially presented special difficulties, particularly when applying previous calcareous nannofossil zonations developed for this area. First, turbidites may have displaced older microfossils into younger units; secondly, the section was possibly contaminated through caving associated with the drilling process, and third, marker species might be mimicked by previously undescribed taxa. In the upper portion of Unit VA especially, nannofossils have been reworked upward. Cores 603B-44 to -46 contain numerous Barremian coccoliths such as Nannoconus colomii (de Lapparent) that have been displaced along with shallowwater holococcoliths by the action of turbidity currents (Covington and Wise, this volume). The prominent upper Aptian coccolith index species Lithastrinus floralis Stradner and Rhagodiscus angustus Stradner are not present, but a form that mimics the latter as well as one that mimics the mid-Aptian index species Hayesites irregularis are. These new taxa are described and differentiated by Covington and Wise (this volume) who date the nannoflora in the sands and silts from Cores 50 to 44 as latest Barremian to earliest Aptian in age. This is in close agreement with the dinoflagellate stratigraphy, which Habib and Drugg (this volume) use to draw the Barremian/ Aptian boundary between Cores 46 and 47 . No other microfossil group was sufficiently well represented in these deep-water sediments to provide reliable age dates; however, data points were sufficiently numerous to allow Ogg (this volume) to recalibrate portions of the Hauterivian/Barremian magnetostratigraphic column.

Wise et al. (1986) considered several possible interpretations for the massive, unconsolidated sands at the top of Unit VA. One possibility, first suggested by JEVH aboard ship and promulgated by van Hinte et al. (1985a), is that they may have been emplaced as the result of the predicted eustatic sea-level drop that had been dated as mid to late Aptian in age (Vail et al., 1977; Vail and Mitchum, 1979; Vail et al., 1980). These sands would then represent what Vail et al. (1984) describe as a Type I unconformity event. A Type I event is caused by a rapid fall in sea level, is characterized by both subaerial and submarine erosion, and results in the construction of a deep-sea fan. The sands at Site 603 do contain displaced inner neritic foraminifers and shell debris (Site 603 chapter, this volume).

The lack of definitive mid to upper Aptian nannofossil assemblages in these sands or in the nannofossiliferous silty clays above them (Core 603B-44), however, presented a problem for the eustatic sea-level hypothesis just described, unless it could be assumed that the sands represented slightly older material eroded and/or slumped from the shelf and slope in sufficient quantity to dilute below the level of detection any slowly accumulating upper Aptian pelagic material. Another possibility suggested by Wise et al. (1986) was that Vail's Type I unconformity event actually had occurred during the early Aptian (at least prior to the first appearance datum of $L$. floralis) rather than during the mid to late Aptian as his charts suggested; in that case, the Vail curve would have to be recalibrated.

As the present volume was going to press, the problem of the time of the Aptian sea-level drop as discussed by Wise et al. (1986) was resolved by an important revision of the Vail curve, based on outcrop studies by the Exxon research group. Haq et al. (in press) now place the event in the early Aptian (base of their Supercycle LZB-4), well below the appearance of the mid to late Aptian nannofossil datums discussed above, which they place in the latest Aptian. This strongly bolsters the case for attributing the sands in Cores 603B-46 through -45 to an early Aptian sea-level drop. It also accords well with the latest onshore drilling results from the Baltimore Canyon Trough, where Edson (1986) describes a major Aptian regression which beveled terrigenous clastics over an extensive area out to the shelf edge. This left, below the disconformity, a seaward-thinning wedge of immature Valanginian-Barremian sediments, the apex of which terminates at the top of a shelf-edge carbonate bank.

Whether one wishes to correlate all of the sands at Site 603 down through the top of Core 603B-49 with the Aptian regression/sea-level drop depends on whether one considers the dinoflagellates up through the lower section of Core 46 to be reworked or not. The heavy mineral assemblages through the entire interval are rather distinct and uniform from Cores 45 to 49 (high in epidote and other metastable minerals-Holmes et al., this volume), but the dinoflagellate assemblages are quite different above and below Section 603B-46-4.

\section{Hatteras Formation (Unit IV)}

At the end of Unit V deposition, the CCD shoaled rapidly, leading to the abrupt loss of calcareous nannofossils. Investigators generally agree that this was the natural result of the sharp sea-level rise predicted by the Vail et al. coastal onlap curve for the remainder of the 
Aptian and Albian. This sea-level rise not only shifted the locus of carbonate deposition from the deep ocean basins to the newly reflooded continental margins, but it also trapped coarse clastics high on the continental shelves, thereby shutting off, in essence, the supply of terrigenous sands to the North American Oceanic Basin and abruptly ending deep-sea fan deposition at our site (van Hinte et al., 1985a; see also discussion by Hay, 1981). This, in turn, set the stage for the accumulation of "black shales" (seen at Site 603 as carbonaceous claystones), which followed during the exceptionally high sealevel stands of the mid-Cretaceous.

During the Cenomanian-Turonian, fleeting blooms of calcareous nannofossils represented only by the genus Nannoconus (Core 603B-35) suggest highly restricted surface-water environments at the peak of "black shale" (carbonaceous claystone) deposition (Hatteras Formation; Subunit IVA). The absence of benthic foraminifers in the black claystone turbidites deposited at Site 603 suggests a greatly expanded oxygen minimum zone on the shelf and slope. Subunit IVA is mostly Cenomanian in age, but extends to the Cenomanian/Turonian boundary. The organic contents range up to $20.4 \%$ by weight (Herbin et al., this volume) and the organic facies is predominantly pelagic (Habib and Drugg; Herbin et al.; Dean and Arthur; Dunham et al.; all this volume). This is the only rich and well-developed organic accumulation at the site that was not largely derived from terrestrial sources.

This well-developed xenomorphic organic facies (Habib and Drugg, this volume) correlates in age with the marine-carbon-rich sapropels at other sites in the North Atlantic (Ryan and Cita, 1977) where it has been variously designated the E2 Event, CTBSH (CenomanianTuronian Black Shales Horizon), or the CTBE (Cenomanian/Turonian Boundary Event) (Herbin et al., this volume). A very rapid rise following a major Cenomanian low stand at $97 \mathrm{Ma}$ (Vail et al., 1977) brought Late Cretaceous sea levels up to some $350 \mathrm{~m}$ above that of today (Pittman, 1978). This is credited by Arthur and his colleagues (Arthur, Dean, et al., 1985; Arthur, Schlanger, et al., 1985) with causing the CTBE, a period of rapid accumulation and burial worldwide of organic-carbonrich strata in response to increased marine productivity (de Graciansky et al., 1984; Arthur, Schlanger, et al., 1986; Schlanger et al., 1986). Arthur and his colleagues attribute this sudden burst of productivity to more rapid deep-water turnover rates as a consequence of the greater production of warm, saline deep water that accompanied the Cenomanian-early Turonian global transgression.

Reddish lithologies and the absence of any organic matter, however, do occur at some intervals of Unit IV (Subunits IVB and IVC). These indicate that the deep basin environment itself was, at least at times, strongly oxidizing.

\section{Plantagenet Formation (Unit III)}

Dark, carbonaceous turbidites continue into the overlying Senonian of Unit III. This lithology accumulated over a longer period of time (late Valanginian to Santo- nian[?] or later-Core 603B-24) at this relatively landward site than in other Atlantic DSDP sites that have recovered "black shales." The same statement can be made concerning terrigeneous siliciclastics that also occur in this unit.

A 4-cm-thick zeolitic claystone in Subunit IIIB (Section 603B-29-2; Haggerty et al., this volume, Fig. 15) probably represents a Late Cretaceous ash fall event. In addition, Huff (this volume) reports a most unusual $\mathrm{X}$-ray diffraction reading for Sample 603B-30-2, 81-85 $\mathrm{cm}$ (Subunit IIIC), which consists of $70 \%$ kaolinite accompanied by $30 \%$ illite, obviously derived from land or a near shore environment. Huff suggests that this could represent an "illite event" as described by Chamley et al. (1983), who relate such occurrences to renewed erosion along the continental margin during episodes of seafloor spreading, such as during the Campanian/Maestrichtian. Unfortunately, cores of Subunit IIIC could not be dated by dinoflagellates. Core 603B-30, however, lies close to the Cenomanian/Turonian boundary (Habib and Drugg, this volume; Herbin et al., this volume) and could be as old as late Turonian, when Haq et al. (in press) record the most profound regression and eustatic sea-level drop of the Late Cretaceous ( $90 \mathrm{Ma}$; base of their Supercycle and Cycle UZA-3.1). This short-term Type I sequence boundary event may well have generated terrestrial runoff and turbidites which could have carried the kaolinite this far out to sea. Type I sequence boundaries also occur in the upper Santonian and the mid-Campanian (Haq et al., in press).

Despite the occasional influx of sand, silt, and mud turbidites, clastic-starved and carbonate-free sedimentation rates during the Late Cretaceous were only $5 \mathrm{~m} / \mathrm{m}$.y. In this "red clay" sequence, there may well be hiatuses which could not be detected because calcareous microfossils or other age-diagnostic fossils are missing. For instance, the striking $\mathrm{K} / \mathrm{T}$ boundary layer with its small spherules (Fig. 8A) represents a high-energy event and appears to have an eroded base. The same holds true for the basal sand of Unit III. This period of sediment starvation was fostered by high sea levels that continued to favor deposition on the continental shelves at the expense of the abyssal plains.

Klaver (this volume) performed detailed geochemical and microscope analyses of the $0.5-1.0-\mathrm{mm}$ dark green spherules that delineate the laminations of the cross-beds in Figure 8A. They consist of thin, smooth-walled glossy outer shells that may be hollow or filled by smaller globular bodies or shrunken cores of Fe-rich montmorillonite (Fig. 12). Identical spherules were found at the $\mathrm{K} / \mathrm{T}$ boundary in a well-dated carbonate section at DSDP Site 390B (personal communication by J. Smit to G. T. Klaver, 1984). Klaver (this volume) reports enrichment of $\mathrm{Zr}$ and $\mathrm{Hf}$ within the cross-bedded layer (according to Klaver, this is indicative of turbidite transport) and enrichments of $\mathrm{Ni}, \mathrm{Co}$, and As in the sediments immediately above. No iridium anomaly was detected by his instrumentation. Nevertheless, he believes that spherules were concentrated and emplaced by a turbidity current which carried material from a $\mathrm{K} / \mathrm{T}$ boundary clay. The finer clay fractions of the turbidite, with anomalously 

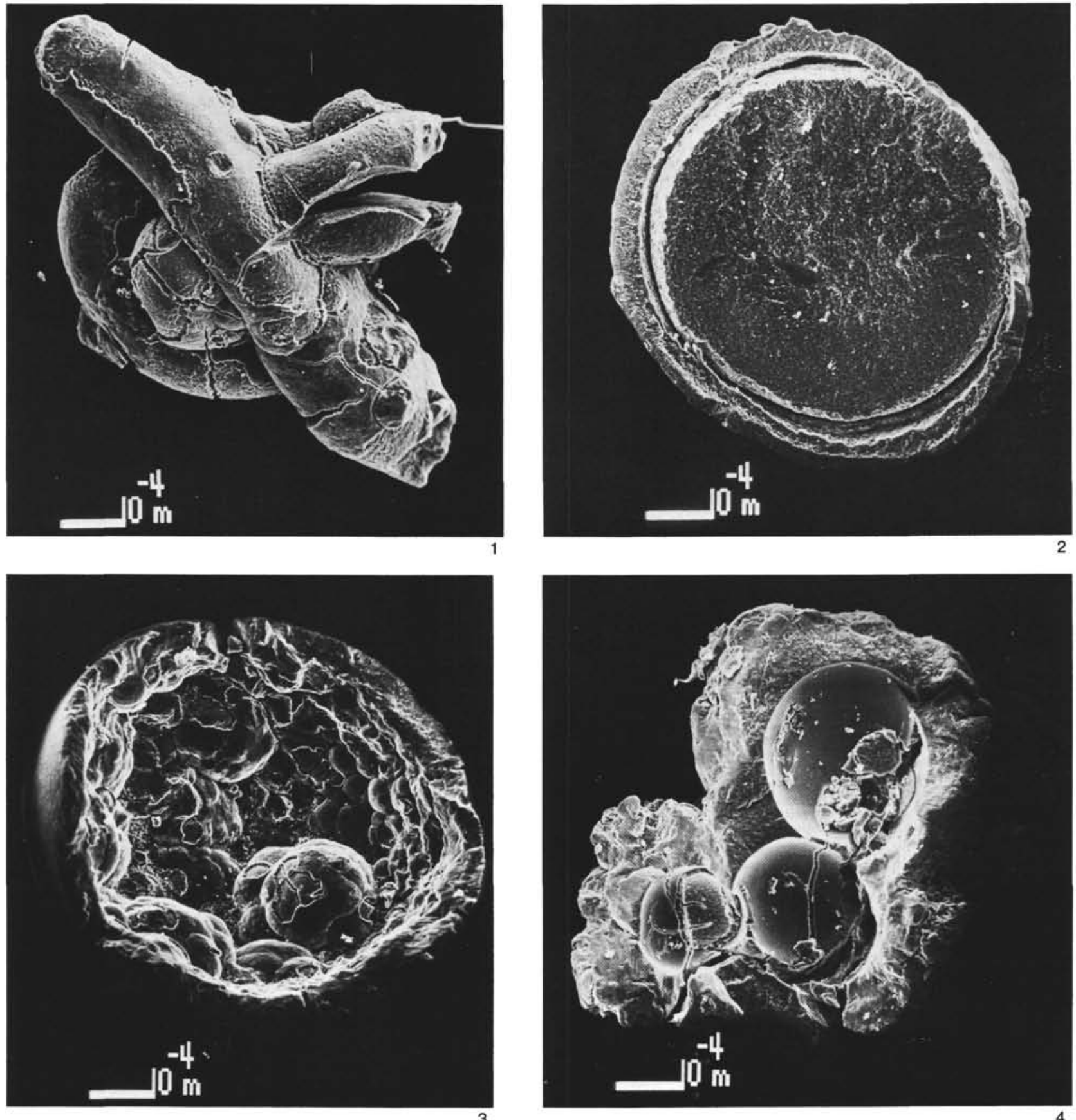

Figure 12. Fe-rich dark green spherules from Section 603B-22-3 (see Fig. 8A, earlier; from Klaver et al., this volume, Plate 3). 1. SEM micrograph of a concretion-shaped particle; cracks are artifacts of SEM preparation. 2. SEM micrograph of a cross-sectioned spherule showing a homogeneous interior mass which, probably because of shrinkage, became largely detached from a massive wall. 3 . SEM view of the nodular inner side of a hollow spherule. 4. Portion of a composite type of spherule with three closely spaced molds from globular bodies; note small pieces of the walls of the globules still adhering to the molds.

high $\mathrm{Ni}, \mathrm{Co}$, and As (and possibly Ir) contents, were deposited above the cross-bedded layer.

\section{Bermuda Rise Formation (Unit II)}

The boundary between Units III and II is marked by a seismic sequence boundary equated with reflection Horizon A*, which was followed by the accumulation of the upper Paleocene-lower Eocene biosiliceous claystones of
Unit II (Bermuda Rise Formation). Site 603 was located just at the presumed feather edge of the Bermuda Rise Formation, where this unit had been truncated by erosion along the lower rise (Fig. 13), so it was not certain if the unit would be encountered at this drill site (see Fig. 2, from the site prospectus). Historically, there had also been some question whether Bermuda Rise type sediments had been present and cored at Site 105 (Ewing 


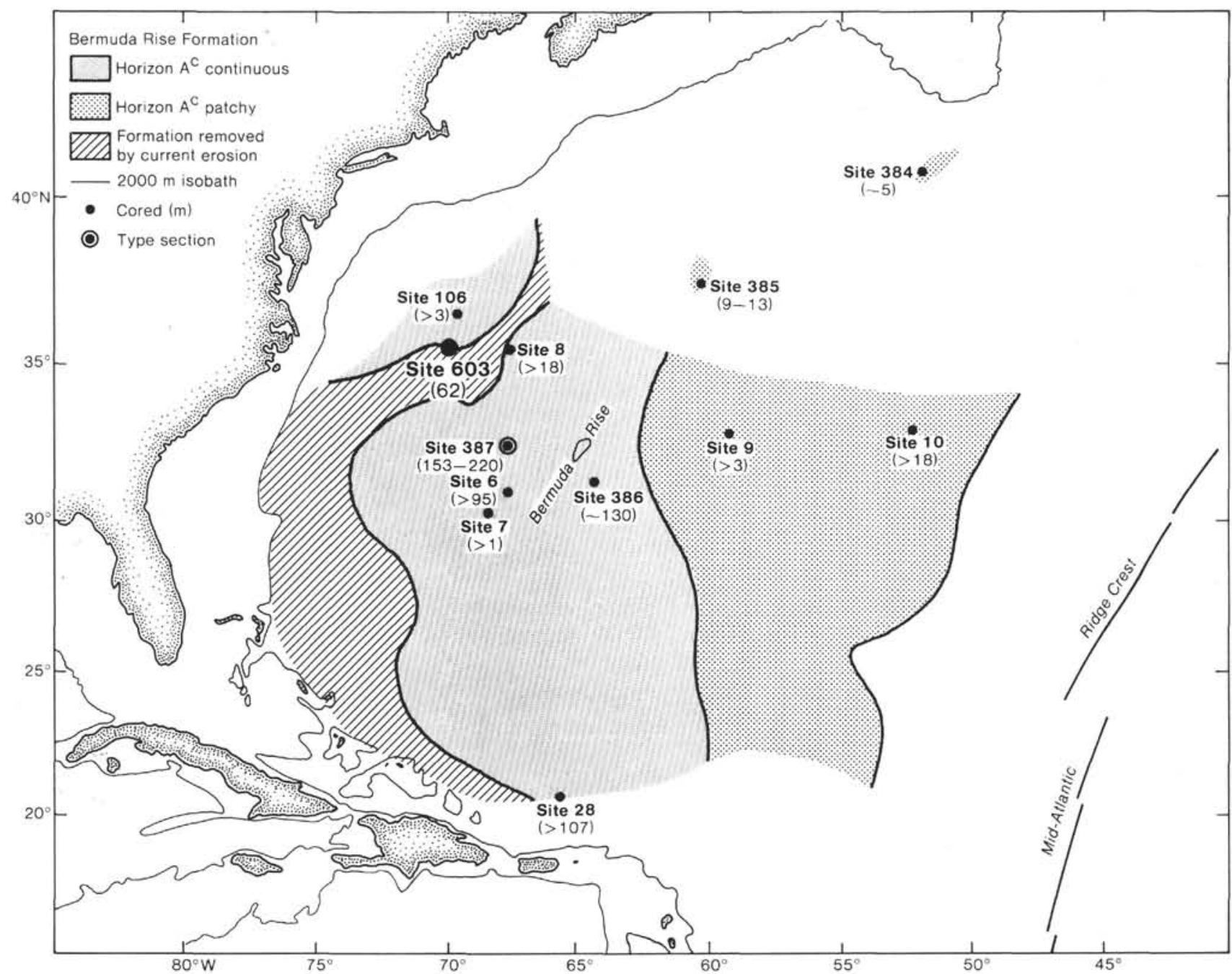

Figure 13. Location of Site 603 near the presumed feather edge of previously mapped occurrences of the Bermuda Rise Formation (modified from Jansa et al., 1979, fig. 15). Formation thickness (m) in parentheses. The suggestion that Horizon $\mathrm{A}^{\mathrm{c}}$ is truncated by Horizon $\mathrm{A}^{\mathrm{u}}$ (erosional unconformity) along the continental margin was confirmed by drilling at Site 603 , but only partially so, in that the lower beds (lower Eocene to Paleocene) of the Bermuda Rise formation are still present. These lower beds are apparently more extensive than indicated by this map.

and Hollister, 1972, and Lancelot et al., 1972, vs. Tucholke, Vogt, et al., 1979a,b; see Site 603 chapter, this volume, for further discussion).

Our drilling demonstrated that the lower portion of the Bermuda Rise Formation was present at Site 603, but that the more silica-rich lower and middle Eocene beds, which provide the strong Horizon $\mathrm{A}^{\mathrm{c}}$ seismic reflection by which the unit had been mapped in this region on single-channel profiles, had apparently been removed along with the upper Eocene sediments. The siliceous beds are distinct, however, on our multichannel seismic profile, where they appear as evenly and closely spaced parallel lines bounded by reflection Horizons A* and $\mathrm{A}^{\mathrm{c}} / \mathrm{A}^{\mathrm{u}}$ (Figs. 5 and 6). Our drilling indicates, therefore, that these lower beds of the Bermuda Rise Formation are more extensive than shown in Figure 13. Robertson (1983) reached the same conclusion for the BlakeBahama Basin, where drilling at DSDP Site 534 also showed the Bermuda Rise Formation to be present.

A question arises whether the clay content of the Bermuda Rise Formation at Site 603 was sufficiently high to inhibit the formation of porcellanite there, thus rendering the unit less easily detectable by seismic reflection (Haggerty et al., this volume). The clay content would not appear to be an important factor, in that porcellanites were well developed in a similar lithology and at a comparable burial depth at the nearby DSDP Site 8 (Fig. 13). Thus erosion of the stratigraphically higher silica-rich beds at Site 603 seems to be the likely cause for the poor development of porcellanites there.

The erosion of the top of the formation, which was caused by a strong southward-flowing boundary current, probably occurred during the Oligocene following Unit II deposition (Mountain and Tucholke, 1985; Hart and Mountain, this volume) to produce the disconformity associated with seismic Reflection Horizon $\mathrm{A}^{\mathrm{u}}$. The disconformity in turn accounts for the sharp contact between Unit II and Unit I (Frontispiece, Fig. A).

The colorful radiolarian claystones of Unit II (Frontispiece, Fig. B) contain manganese nodules in the reddish brown (oxidized) facies and rhodochrosite nodules disseminated in the greenish grey, more organic-matter- 
rich (partially reduced) facies (von Rad and Botz, this volume; Haggerty et al., this volume). They are enriched in transition elements (examples, $\mathrm{Cu}, \mathrm{Co}$, or $\mathrm{Ni}$ ) as well as in manganese oxide (Dean and Arthur, this volume).

The origin of these metals mentioned above in the Bermuda Rise Formation and particularly in the underlying Plantagenet Formation in the North American Basin has long been the subject of interest and debate (see summary by Arthur, 1979, and by Robertson, 1983). Lancelot et al. (1972) suggested metal enrichment from volcanic exhalations. For the Plantagenet Formation Murdmaa et al. (1978) related it to slow sediment accumulation, as did Robertson (1983), who proposed that the metals could be scavenged from strongly oxidizing bottom waters, then redistributed within the sediment during diagenesis to produce the color banding and mottling. On the other hand, Arthur (1979; and Arthur and Dean, this volume) suggested that the enrichment was caused by the upward diffusion of elements from the interbedded carbonaceous claystones of the Hatteras or Plantagenet formations (Units IV or III), which would then precipitate in the more oxidizing environment of the Plantagenet Formation.

Eocene claystones somewhat similar to those in Unit II were recovered at DSDP Site 550 on the Goban Spur off the Irish coast. These display Mn dendritic coatings and crusts enriched in $\mathrm{Ni}, \mathrm{Co}$, and $\mathrm{Ba}$, which Karpoff et al. (1985) believe are related to the halmyrolysis of volcanic clastic and biogenic components in an open, deepwater, oxidizing environment during times of slow deposition. This explanation may well apply for the colorful Eocene sediments at Site 603, which were deposited during a time of active volcanism in the Antillean arc region to the south (Gibson and Towe, 1971) and perhaps even closer to Site 603 (see discussion of rhyolitic ash deposition at Site 605 , later).

\section{Significance and Regional Setting of the Cape Hatteras Deep-Sea Fan Complex at Site 603}

The discovery of a major, Lower Cretaceous, passivemargin, deep-sea fan complex which consists of up to $47 \%$ sand over a $218-\mathrm{m}$ interval and is located $320 \mathrm{~km}$ seaward of the Cretaceous shelf edge was a surprise. The possibility that coarse clastics may have bypassed the Early Cretaceous shelf break to accumulate at the foot of the slope had only been suggested speculatively in recent assessments of the stratigraphy and petroleum potential of the eastern North American continental margin (Jansa and MacQueen, 1978; Mattick et al., 1978). Tucholke and Mountain (1979) had observed that the distinct, high-amplitude Reflector $\beta$ seen in profiles at great distance from the North American margin deteriorated landward of the lower rise, and they concluded that terrestrial contributions during the Hauterivian-Barremian were the cause. No such clastic sediments had been found, however, in rocks of this age cored at DSDP Site 105 just $60 \mathrm{n}$. mi. southeast of Site 603 , and the possibility of coarse clastics in any quantity reaching these distant localities was not generally anticipated. The only firm indication that such a deposit might have existed was given by the presence of coeval coarse turbidites at DSDP Sites 391 and 534 to the south (Blake-Bahama Basin; Sheridan, Gradstein, et al., 1983).

\section{Shelf-Edge Reefal Bank and Siliciclastic Deposition}

One reason not to suspect widespread dispersal of Lower Cretaceous siliciclastics into the deep sea was the belief that an extensive reef/carbonate bank complex might have existed along the outer continental shelf from Mexico to Nova Scotia during the Early Cretaceous (Emery and Uchupi, 1972, p. 97; see also Emery et al., 1970, fig. 38). This suggestion was based on the recovery of Lower Cretaceous reefal limestone as far north as Flemish Cap on the Grand Banks. Originally dated as Albian, the Flemish Cap dredge hauls were later redated as early Aptian (Gradstein et al., 1977). Along the Atlantic margin, then, this outer shelf reef/carbonate bank system, plus the slow but progressive rise of Neocomian eustatic sea levels (Sliter, 1977; Vail et al., 1977), could have effectively confined most terrigenous clastics to the inner continental shelf (particularly in downfaulted depocenters such as the Baltimore Canyon Trough (Fig. 14). Presumably, little clastic material would have bypassed the reefs to the deep-sea environment.

Schlee et al. (1976), however, noted the absence of evidence for reefs on their multichannel line 3 across the southern Baltimore Canyon Trough, and Mattick et al. (1978) commented that carbonate deposition there might be incompatible with prograding deltas in that region. Jansa (1981) emphasized that the Jurassic-Lower Cretaceous carbonate platforms and banks form a discontinuous belt, albeit one that extends over a distance of $6000 \mathrm{~km}$ from the Bahamas to the Grand Banks. He noted, for example, that the carbonate belt in the Scotian Basin had been breached by the local development of prograding clastic deltas (Jansa and Wade, 1975).

Closer to our study area, Poag (1982) suggested that deltaic clastics had probably overstepped the shelf edge along Georges Bank during the Hauterivian-Barremian. Based on our initial shipboard observations, we questioned whether post-Valanginian reefs could have existed along the Baltimore Canyon Trough (Leg 93 Staff, 1983; see also van Hinte et al., 1985a). In addition to the turbid water conditions that must have prevailed on the shelf by that time, we noted no fragments or traces of framework building organisms (such as rudistids or coralline algae) in the turbidites swept down from the shelf to our drill site. Studies of shelf wells and multifold seismic profiles (Libby-French, 1984; Mountain and Tucholke, 1985; and Poag, 1985b) also suggested that Hauterivian to Barremian clastics had overstepped the shelf-edge carbonate bank or reef in the Baltimore Canyon area, thereby shedding detrital sediments down the slope beyond. For the seismic interval between $\mathrm{J}_{1}$ and $\beta$, Uchupi et al. (1984a, b) map these sands as extending about one half the distance from the Mesozoic shelf break to Site 603 . For the interval immediately above $\beta$ (which would include the massive sands in our cores 603-44 to -48), they map no sands beyond the Cretaceous shelf break. Our drilling results, of course, clearly demon- 


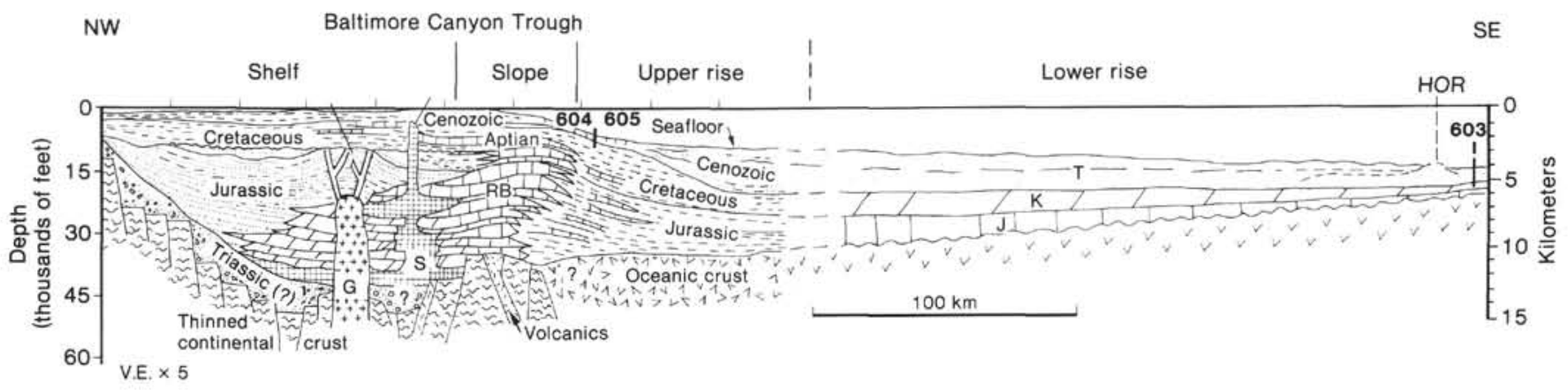

Figure 14. Schematic section through the New Jersey continental margin and DSDP Sites 604/605 extended to Site 603 on the lower continental rise (after von Rad et al., 1984, as modified from Schlee and Jansa, 1981). G = Great Stone Dome, S = salt diapir, HOR = Hatteras Outer Ridge (continental rise hills); $\mathrm{J}=$ Jurassic, $\mathrm{K}=$ Cretaceous, $\mathrm{T}=$ Tertiary.

strated that large amounts of terrigenous HauterivianAptian sands had overstepped or bypassed the outer shelf reefal bank to spread over the abyssal plain hundreds of kilometers beyond.

The latest drilling results from commercial wells along the outer shelf of the central Baltimore Canyon Trough indicate close parallels between the Early Cretaceous depositional histories at Site 603 and the adjacent shelf/ upper slope. Edson (1986), Karlo (1986), Ringer and Patten (1986), and others have reported in abstract the development there of the Upper Jurassic-Lower Cretaceous shelf-edge carbonate buildup.

According to these authors, the carbonate reef/bank prograded seaward from Oxfordian through early Kimmeridgian times in the face of high clastic input from the continent. It then experienced rapid aggradation of shallow-water bioclastic debris, culminating with a drowning episode during the Valanginian that left a deeperwater biota and pinnacle-like features visible on seismic lines along the reef trend. Erosion (probably submarine) later during the Valanginian, however, cut and sculptured the bank into segments. Hummocky seismic reflectors within a series of "mesa-like" features represented bioclastic debris when drilled. It was possibly during this erosional episode that breaches were cut in the reefal bank through which siliciclastics could pass to the deep sea (E. Ringer, personal communication, 1986), for it was shortly thereafter in the latest Valanginian that mud and then quartz sand turbidites began to arrive at Site 603.

In the back bank area, immature Valanginian-Barremian continental clastics accumulated to form a seawardthinning wedge that buried the shelf edge, spilling over intermittently during the Hauterivian-Barremian. Thereafter followed the major early Aptian regression that beveled the Neocomian clastic wedge out the top of the carbonate bank. During the subsequent Aptian transgression, a 200-400 ft. thick "blanket-like" carbonate unit was deposited over the disconformity (Edson, 1986). This strongly reflective unit, which represents progradational, shelf-margin carbonate shoals of Aptian age (Ringer and Patten, 1986), is apparently the unit designated as the Hauterivian "O” Marker by Poag (1985b, figs. 6-2, 6-3, and 6-4), who shows it draping the massive pre-Hauterivian reef/bank complex.

\section{Siliciclastic Sources}

Although the deposition of siliciclastics appears to mirror rather faithfully the progradation of terrestrial deltas through the depocenter of the central and northern Baltimore Canyon Trough, this well-studied area was probably not the primary source for the clastics that arrived at Site 603. The seismic mapping along the slope and rise by Mountain and Tucholke (1985) coupled with the heavy-mineral study by Holmes et al. (this volume) suggest that the main source lay to the south, where clastics would have a more direct input to the deep sea through the heart of the Salisbury Embayment and across the southernmost portion of the Baltimore Canyon Trough.

At Site 603, seismic reflection Horizon $\beta$ is picked at $1265 \mathrm{~m}$ (Core 49, uppermost Barremian), at the level of the highest in situ pelagic limestone beds in the section. The map by Mountain and Tucholke (1985) for the interval corresponding to the Tithonian through Barremian (between Horizons $J_{1}$ and $\beta$ ) indicates the existence of a number of depocenters along the base of the slope fed by submarine canyons from the Georges Bank to the southern Carolina Trough (Fig 15). During this time, the fan developing at Site 603 could have received sand turbidites funneled through more than one of these depocenters. Indeed, Holmes et al. (this volume) postulate that the rather diverse heavy-mineral assemblage through most of the lower fan sediments represents a mixture from three different sources.

Site 603, however, is separated from the large Georges Bank depocenter by an intervening area of high basement topography which probably shielded it to some extent from turbidites originating at this more distant locality (G. S. Mountain, personal communication, 1984). Instead, the site is directly in line with the extensive depocenter to the WNW off the central Salisbury Embayment (southern Baltimore Canyon Trough). The depocenters in the vicinity of the COST B-2 and B-3 wells in the central Baltimore Canyon Trough are thick, but are of more modest extent despite the fact that Libby-French (1984) records a major source of Neocomian clastics (Missisauga-equivalent) entering from the northeast (ancestral Hudson River). Her cross sections show these beds pinching out to the south, however, in the central Baltimore Canyon Trough (Libby-French, 1984, fig. 12). Sands 


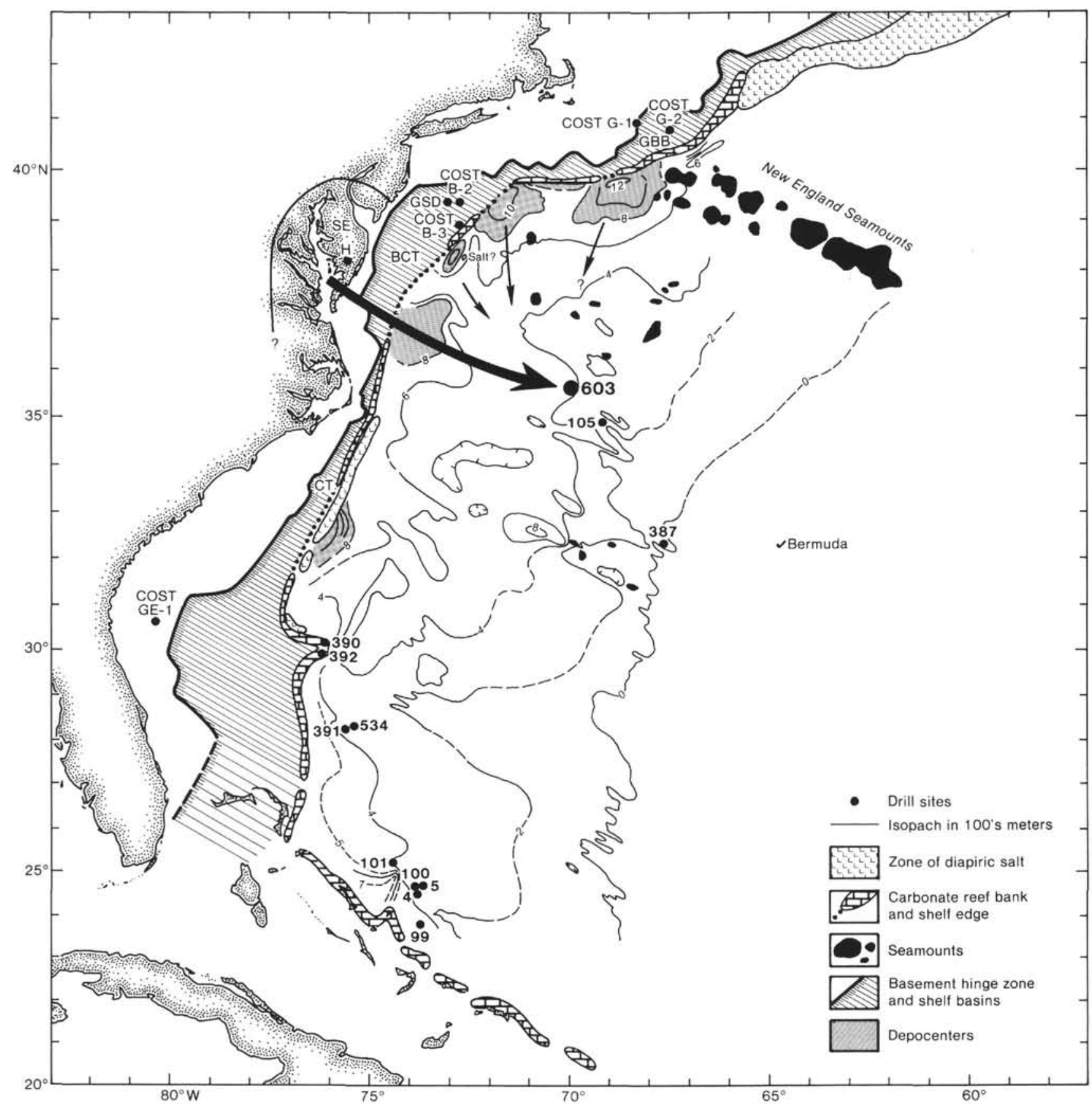

Figure 15. Pre-Aptian Lower Cretaceous sediment isopach between seismic reflection Horizons $\mathrm{J}_{1}$ and $\beta$ (after Mountain and Tucholke, 1985, fig. 8-15). Superimposed arrows indicate the probable major and minor source directions for the lower fan siliciclastics (Cores 603B-76 to 50) deposited at Site 603 (based on this isopach map and the provenance of the heavy mineral assemblage-see Holmes et al., this volume). Note discontinuous shelf-edge reefal bank along the Baltimore Canyon Trough. SE = Salisbury Embayment (from Owens and Gohn, 1985), $\mathrm{CT}=$ Carolina Trough, GBB $=$ Georges Bank Basin, BCT $=$ Baltimore Canyon Trough, $\mathrm{H}=$ Hammond Well, GSD $=$ Great Stone Dome.

bypassing the shelf in the vicinity of the B-3 well would also be partially shielded from Site 603 by intervening basement topography.

Mountain and Tucholke's (1985) Horizon $\beta-\mathrm{A}^{*}(=$ Aptian to Maestrichtian) sediment isopach map (Fig. 16), when compared to the previous time slice in Figure 15, indicates fewer but larger depocenters along the foot of the slope. These perhaps denote the development of more mature and better organized drainage systems in the watershed as erosion beveled the hinterland through the mid-
Cretaceous. Because clastic supplies to the deep sea during the Late Cretaceous were minimal on account of high eustatic sea levels, much of the sediment mapped in these depocenters may be Aptian in age. The contours again indicate a major source toward the west in the central or southern Salisbury Embayment for the Site 603 Aptian siliciclastics.

The heavy mineral analysis by Holmes et al. (this volume) again tends to support this interpretation. Staurolite is an important minor component in the lower fan 


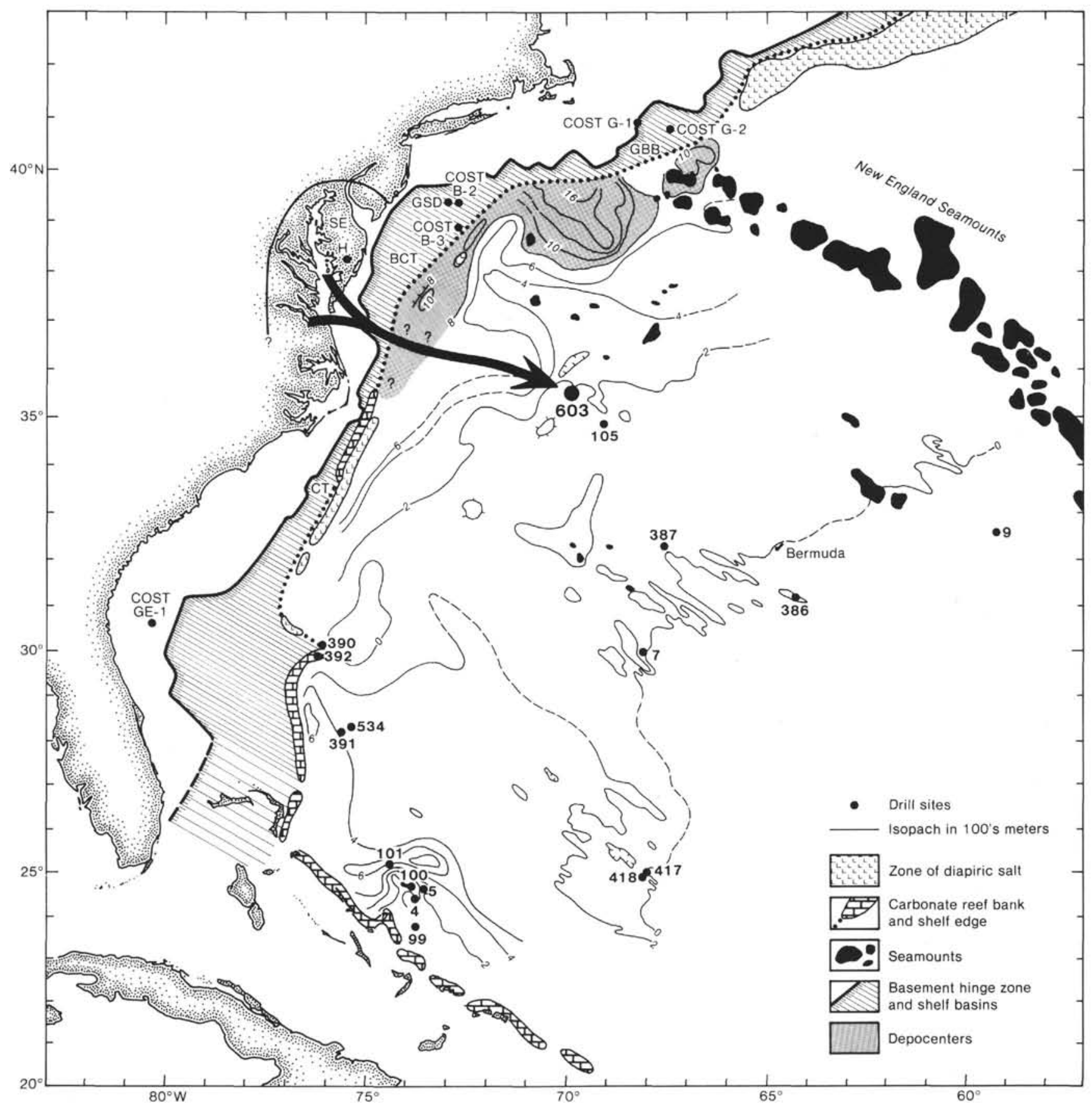

Figure 16. Post-Barremian Cretaceous sediment isopach between seismic reflection Horizons $\beta$ and A* (after Mountain and Tucholke, 1985, fig. 8-16). Superimposed arrow indicates the primary source direction for the upper fan siliciclastics (Cores 603B-49 to -45) deposited at Site 603 (based on this isopach map and the provenance of the epidote-rich heavy mineral assemblage-see Holmes et al., this volume). Note absence of a shelf-edge reefal bank along the Baltimore Canyon Trough (BCT). SE = Salisbury Embayment (from Owens and Gohn, 1985), CT = Carolina Trough, GBB $=$ Georges Bank Basin, BCT $=$ Baltimore Canyon Trough, H $=$ Hammond Well, GSD $=$ Great Stone Dome.

sediments at Site 603 , but is the only metastable heavy mineral that does not increase in abundance in the Aptian sand cap, where it drops to very low values. This trend is mirrored in the coastal plain of the central Salisbury Embayment, where staurolite is the most abundant (in fact dominant) heavy mineral in the Neocomian sediments of the Patuxent Formation (lower Potomac Group, Hauterivian[?] to Barremian) but not in the superjacent Patapsco Formation (upper Potomac Group, Aptian[?] to Albian in age). This decline in staurolite, so noticeable at Site 603 and in the Salisbury Embayment (Holmes et al., Table 1), is not evident from the literature on the COST B-2 well of the central Baltimore Canyon Trough. There Smith (1980) surveyed a suite of eight Neocomian through Albian samples, and staurolite remained a minor component throughout. As indicated by the work of Libby-French (1984), the delta front in the northern Baltimore Canyon Trough probably had a different source 
from that of the Potomac Group in the Salisbury Embayment.

Conversely, the most striking change in the heavy mineral assemblage at Site 603 was the flood of epidote beginning in Core 603B-49 and extending through the massive Aptian sand cap (note however, that epidote had begun to increase in concentration before that time, during the peak of early Barremian turbidite deposition; Holmes et al., this volume). There is only one report of abundant epidote from the Coastal Plain and outer continental shelf studies, and that is in Patapsco Formation (upper Potomac Group) sediments from a well located on the southern end of the eastern shore of Maryland (Anderson, 1948), along the axis of the Salisbury Embayment. The source for this epidote would likely be the epidote-enriched formations of the Piedmont and Blue Ridge (Holmes et al., this volume).

Unfortunately, no exploratory wells have been drilled in the southern Baltimore Canyon Trough; thus the stratigraphy and structure of that region can only be inferred from seismic studies. G. Edson (personal communication, 1986) reports conspicuous erosion of the Neocomian carbonate shelf-edge rim in that direction. It appears to be faulted, eroded, or even absent along some seismic lines, where it seems to have been replaced by clastics. These observations accord well with the data reported by Schlee et al. $(1976,1979)$ and Mountain and Tucholke (1985; see reef trend in Fig. 15). The Cretaceous carbonate reef/bank may have never formed in some of these localities, thus the flow of clastics through the Salisbury Embayment may not have been impeded in some areas by either a reef barrier or a deeply subsiding basin.

\section{Ultimate Causes of Siliciclastic Deposition}

As discussed earlier, the deposition of deep-sea siliciclastics at Site 603 as well as at Sites 391 and 534 to the south coincides with a major progradation of terrestrial deltas on the adjacent continental shelf. A similar phenomenon has been recorded in the southern Wessex Basin of England (Wealden Beds), and deep-sea fans of this age have been cored off northwest Africa at DSDP Sites 370 and 416 (Lancelot, Winterer, et al., 1980). Our estimate of the extent of these deposits is given in Figure 17 (from Wise et al., 1986; see also Sarti and von Rad, this volume). Hallam (1984) reviews the occurrence of this "Wealden-type facies" throughout the Tethyan-mideastern realm (see also Emery and Uchupi, 1984; Sarti and von Rad, this volume). He attributes the initiation of this widespread siliciclastic deposition in the circumNorth Atlantic to climatic change from arid conditions prevalent during the Late Jurassic, to more humid environments during the post-Berriasian Cretaceous. This is opposed to, but not incompatible with, explanations that suggest tectonic uplift in various regions during the $\mathrm{Ne}$ ocomian (see summaries by Emery and Uchupi, 1984).

For our study area, there is growing evidence to suggest that tectonic disturbances during the Neocomian rejuvenated source areas from the Maritime provinces of Canada down through the eastern Appalachian trend. This evidence includes volcanism associated with the rifting of the Scotian margin (particularly the late stages) from inland locations in central New England and Quebec (Foland and Faul, 1977; McHone, 1978) to the Scotian Shelf (Jansa and Pé-Piper, 1985), Georges Bank (Hurtubise and Puffer, 1985; Hurtubise et al., in press), and the Baltimore Canyon Trough, which witnessed the emplacement of the mafic pluton called Great Stone Dome (Fig. 17) around Aptian times (Grow, 1980; Amato and Giordano, 1985). These volcanic events are mirrored by apatite fission track data from eastern New York and Pennsylvania that signify significant Early Cretaceous tectonic uplift starting at about $135 \mathrm{Ma}$ (Duddy and Miller, 1986). Dates for a number of these events cluster about the Hauterivian/Barremian, but some also range into the Aptian.

Jansa and Pé-Piper (1985) and earlier workers note that the igneous complexes on land may represent the continental extensions of North American Basin fracture zones and seamount chains; therefore rejuvenation of source areas along these zones could occur through plate-motion changes, such as when seafloor spreading began in the Labrador-Greenland and south Atlantic regions. The Baltimore Canyon area may have been in the range of influence of the continental extension of the New England Seamount Chain (Amato, 1985; personal communication, 1985). Whatever the exact causes, crustal extension and rifting between the Iberian and Scotian/Newfoundland margins occurred over a long period of Neocomian time (ODP 103 Staff, 1986), and were followed or accompanied by subsequent rifting and plate reorganization in the North Atlantic region through Early Cretaceous times. These tectonic perturbations, we believe, were sufficient to help alter the Early Cretaceous depositional regime in our study area from basically a carbonate-dominated shelf/slope-rise environment to a detrital clastic one. Highly detailed studies will be necessary, however, to distinguish unequivocally among climatic, tectonic, or eustatic sea-level changes as the principal agents in the depositional patterns seen at Site 603 and on the adjacent shelf.

\section{Early Aptian Eustatic Sea Level Event}

At present, we consider tectonic and possibly climatic events the most likely causes for the Valanginian-Barremian progradation of the onshore deltas in the face of rising sea levels and for the concomitant development of the lower fan sequence at Site 603. The character of the Aptian sediments at Site 603, coupled with what is known of the geology along the shelf, however, suggest, as argued previously, that a sharp relative (and probably eustatic) sea-level drop was responsible for exposure and beveling of the shelf and for the deposition of the massive Aptian unconsolidated sands at the top of the turbidite sequence.

Wise et al. (1986) called attention to a local disconformity over the Great Stone Dome, which Grow (1980) mapped and which he suggested was formed when the intrusion was emplaced around Aptian times. This intrustion and associated uplift may have created an important point source for lower Aptian sediments eroded off the shelf. This disconformity, however, although originally considered local in extent, coincides with the more 


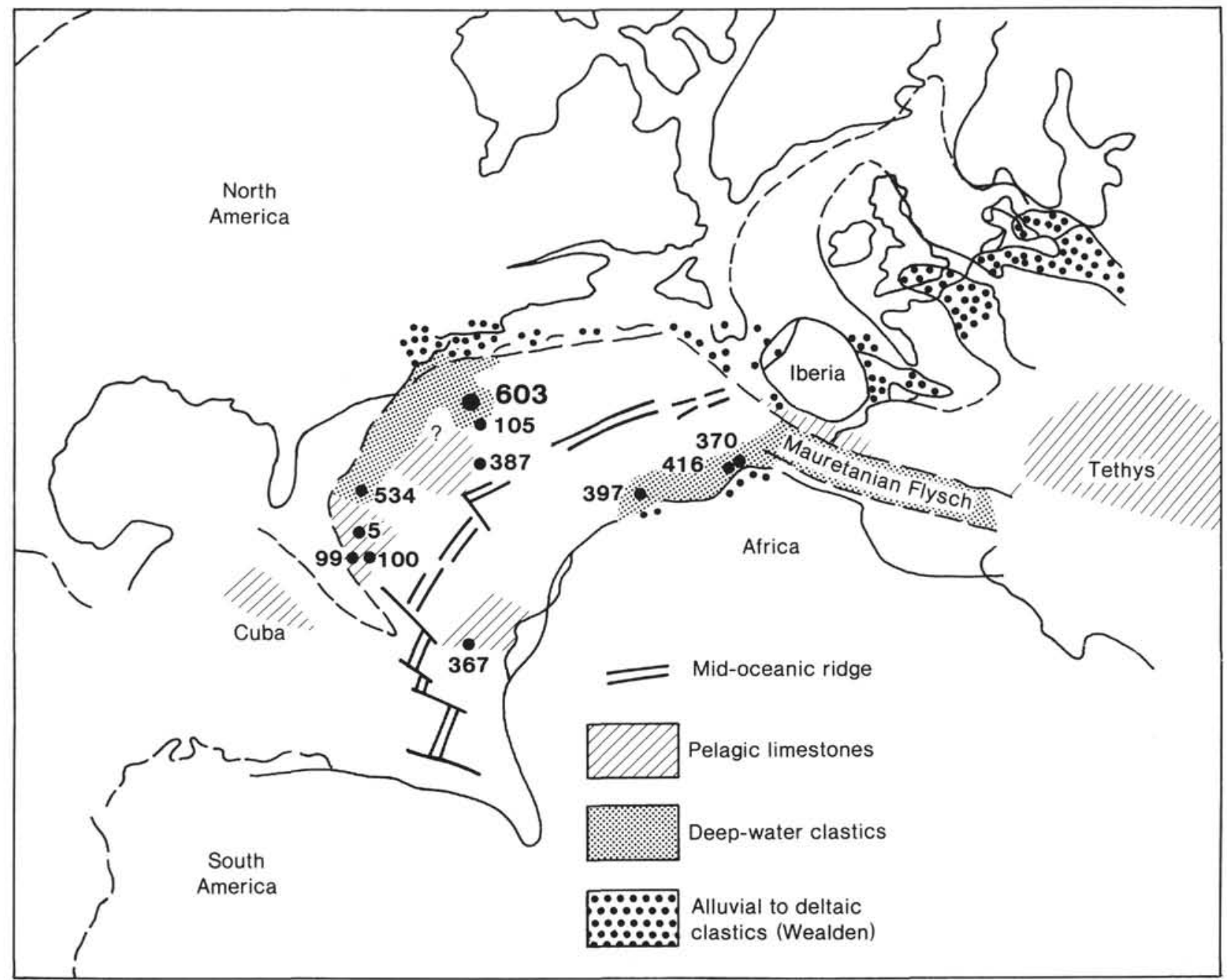

Figure 17. Early Cretaceous paleogeography of the North Atlantic region showing the distribution of pelagic limestone, deep-water clastic, and alluvial to deltaic (Wealden) facies. Generalized from von Rad and Arthur (1979) and Robertson and Bernoulli (1982) and supplemented using DSDP Leg 76 and 93 data.

extensive one recorded by Edson (1986), and it can be traced widely along the eastern seaboard from the Norfolk high (P. R. Vail, personal communication, 1983) to the Georges Bank (E. Ringer, personal communication, 1986). The "pre-Aptian" unconformity described by Williamson (in press) in wells of the Hibernia oil field off New-foundland appears to lie at a similar stratigraphic level, although this area is structurally more complex. Rawson and Riley (1982), however, indicate a similar disconformity in the North Sea area where the structure is less complicated. It is on these kinds of evidence, plus outcrop studies in France, that Haq et al. (in press) indicate a profound eustatic sea-level drop at this point in the geologic column.

To prove that the early Aptian event is eustatic in the purest sense (and not a more regional tectonic pulse) would require its documentation on passive margins well outside the circum-North Atlantic, where synchronous plate-tectonic readjustments may have been recorded on either side of the seaway. A similar lower Aptian stratigraphic record on the passive margins of Australia or Antarctica would provide convincing proof. At present, we accept the evidence of a major early Aptian eustatic event. We believe, therefore, that Early Cretaceous sedimentation at Site 603 proceeded as shown in Figure 18, which incorporates aspects of the model of Sarti and von $\mathrm{Rad}$ (this volume) as well as the latest drilling results from the Baltimore Canyon Trough.

\section{Petroleum Potential}

The arkosic sand turbidites at Site 603 were interbedded with organic-matter-rich claystones in deep-sea fan complexes along the continental rise and abyssal plain, later to be covered by younger deposits consisting predominantly of clays. This suggests that many of the ingredients considered favorable for petroleum accumulation are present in this passive-margin, deep-sea environment. Porosities and permeabilities of some of these sands and sandstones can be quite high (M. Johns, personal communication, 1984), particularly in the Aptian sand cap. In addition, the feldspathic nature of these sediments is amenable to diagenetic patterns of calcite replacement and dissolution that can produce good secondary porosity and permeability under the proper con- 
ditions (Prezbindowski and Pittman, this volume; D. Prezbindowski, personal communication, 1984). This diagenesis can apparently occur at in situ temperatures lower than those previously estimated (Prezbindowski and Pittman, this volume).

Unfortunately, the quality of the largely terrestrially derived organic matter in the Cape Hatteras Fan Complex is not favorable for hydrocarbon generation (Fig. 19; see Meyers, this volume, for detailed discussion); it would produce primarily gas rather than petroleum. The quality and amount of the organic matter may change toward the upper slope, however, where an expanded oxygen minimum layer may have promoted greater accumulation and better preservation of these materials. Sand units may also thicken in that direction before wedging out updip against the slope. Sarti and von Rad (this volume) emphasize that the thickest and most extensive deep-sea fan lobes should be those deposited at times of rapid decline in sea-level, such as during the Aptian.

Although no mature hydrocarbons were found at the relatively shallow burial depths at Site 603 , these might be present under deeper burial conditions of the kind that would exist at more landward localities, such as along the nearby Carolina Trough (see fig. 13 of Hutchinson et al., 1983) (van Hinte et al., 1975a; Wise et al., 1986; see also Katz, this volume). We believe that it is a logical area for future exploration, particularly in paleoslope environments. These were only marginally tested during the drilling along the carbonate bank and inner shelf areas of the central and more northerly areas of the Baltimore Canyon Trough. In addition, little is known about the clastic deposits that may fill the breaches through the shelf-edge reefal banks.

\section{Conclusions}

The implications of the discovery of the deep-sea fan complex at Site 603 are multifaceted and will long be the subject of continuing research. At this point, however, we conclude that:

1. Large deep-sea fan complexes are present along the older passive margin of eastern North America.

2. These complexes probably resulted from a change to more humid climates coupled with tectonic uplift of the hinterland; this tectonic rejuvenation of source areas was associated with the rifting and plate reorganization that accompanied the final separation of North America and Europe.

3. Sea-level changes influenced the mode and style of deposition of the fan deposits. Although the progressive but slow worldwide sea-level rise from the Hauterivian to the early Aptian did not prevent the outpouring of terrestrial clastics along the shelves and rises of the North American Atlantic margin, the presumption by P. Vail and his colleagues of an early Aptian drop and subsequent rise in sea-level (as recently recalibrated) is supported and recorded in a massive deep-sea sand deposit. This in turn was followed by the cessation of sand turbidite deposition and a sharp rise in the CCD at Site 603 during the subsequent transgression and sea-level rise.

4. The progradation of the huge "Wealden-type" deltas across the adjacent shelf was likewise in response to a shift to a more humid climate (Hallam, 1984) and to a rejuvenation of source areas along the eastern Appalachian trend caused by tectonic uplift associated with plate readjustments and rifting that affected regions to the north.

5. The continental rise and slope environments of this passive margin should not be neglected as a potential petroleum province, despite the recent disappointments encountered in drilling the adjacent outer shelf.

6. The extent of Early Cretaceous reef development can be reassessed, particularly since breaches through that trend must have been present to allow the outflow of clastic sediments through areas such as the Salisbury Embayment.

7. The absence of sand turbidites at DSDP Site 105 is probably due to its location on a basement high. The turbidite flows were largely confined within channel-levee systems at Site 603 , and must have carried their loads some distance seaward. The density currents, however, would have flowed around topographic highs.

8. The presence of sand turbidites at Site 603 distinguish the Blake-Bahama Formation there from its previously recorded occurrences elsewhere. Thus, we informally differentiate a "sandy" and a "limestone" facies of the formation at this locality (Fig. 6).

9. Lateral and vertical sedimentary facies changes are far more rapid and complex beneath the continental rise than in the more seaward environments traditionally explored by deep-sea drilling. More deep-penetration holes will be necessary so that we can better understand this important continental margin province.

\section{DSDP SITES 604 AND 605 AND OTHER INVESTIGATIONS OF THE UPPER CONTINENTAL RISE AND SLOPE ALONG THE "NEW JERSEY TRANSECT"}

In part because of the recent advent of commercial petroleum exploration in the area, the geologic framework and depositional history of the outer continental shelf and slope along the Baltimore Canyon Trough are relatively well known and have been summarized by Schlee et al. (1976), Schlee (1981), Libby-French (1984), Poag and Schlee (1984), and Poag (1985b). In addition, investigators such as Schlee et al. (1979), Robb, Hampson, Kirby, et al. (1981, 1983), Robb, Hampson, and Twichell (1981), Robb (1984), McGregor et al. (1982), Stubblefield et al. (1982), Prior et al. (1984), and Stanley et al. (1984) have undertaken a variety of geological, geophysical, or manned submersible surveys to explore the continental slope and canyon systems. In contrast, data on the continental rise, particularly in intercanyon areas, are more limited, and early attempts at deep sea drilling there recovered only a few shallow cores (Hollister, Ewing, et al., 1972).

To help tie the Cretaceous-Pleistocene sequence at DSDP Site 603 on the lower continental rise (Fig. 1) into the onshore and offshore geology of the Baltimore Canyon Trough area, we drilled a series of shallow holes on the upper continental rise some $100 \mathrm{n}$. mi $(161 \mathrm{~km})$ southeast of Atlantic City, New Jersey. This drilling was part of the New Jersey Transect, completed on Leg 95 (Leg 
S. W. WISE, JR., J. E. VAN HINTE
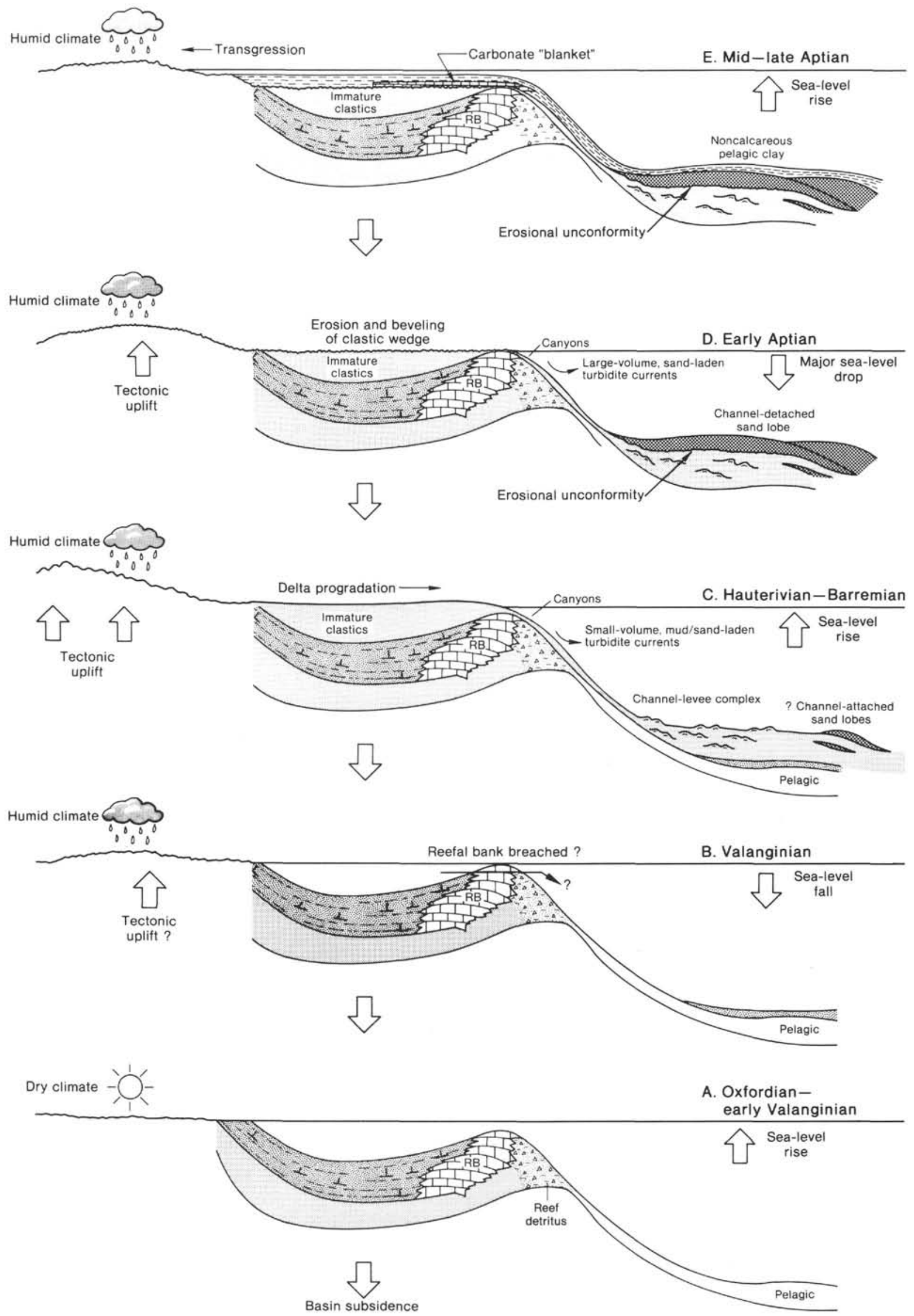
95 Scientific Party, 1984); it consists of sites along or near U.S.G.S. multichannel line 25 , which trends southeast across the continental slope and rise (Fig. 20). These sites can be joined with existing wells along the shelf and in the deep sea to form the first comprehensive downdip transect of a passive continental margin from the coastal plain to the abyssal plain. The drilling objective at all sites was strata of Campanian age or younger. The chief scientific objectives of the overall study, as formulated by the IPOD Planning Committee and the Passive Margin Panel, were:

1. To document the presence of unconformities, and to determine their nature, age, correlation with seismic discontinuities, and relationships to sea-level fluctuations;

2. To examine the relationship between the faunal and lithic compositions and the variable character of seismic sequences seen on line 25 ;

3 . To describe and correlate litho- and biofacies sequentially along the transect; and

4. By virtue of the above, to document the upbuilding, outbuilding, and subsidence history of this passive margin.

DSDP Site 604 was located in $2364 \mathrm{~m}$ of water on the uppermost continental rise, $97 \mathrm{n} . \mathrm{mi}(156.5 \mathrm{~km})$ southeast of Atlantic City, New Jersey (Figs. 1 and 20, Table 1) and $231 \mathrm{n}$. $\mathrm{mi}(372 \mathrm{~km}$ ) from Site 603 (Fig. 14). Site 605 was spudded in $2194 \mathrm{~m}$ of water, washed to $154 \mathrm{~m}$ subbottom, and continuously cored to $816.7 \mathrm{~m}$ (Figs. 21 and 22; Table 1).

\section{Stratigraphy}

The lithologic units penetrated at Site 604 between 0 and $295 \mathrm{~m}$ are shown in Figure 22. From top to bottom they are:

Unit I: $84 \mathrm{~m}$ of Holocene(?) to Pleistocene gray to dark greenish gray clays and silts in alternating sequences. This unit contains reworked Eocene and Neogene microfossils, has some slumped or redeposited Eocene biosiliceous chalk in the upper $35 \mathrm{~m}$ (Subunit IA) and has internal slump structures in the lower part (Subunit IB). Displaced shallow-water benthic foraminifers are particularly common in beds characterized by cold-water planktonics (glacial stages).

Unit II: $155 \mathrm{~m}$ of lower Pleistocene to upper Miocene greenish gray clay with variable amounts of glauconite shelf sand turbidites and biogenic silica. This unit is di-

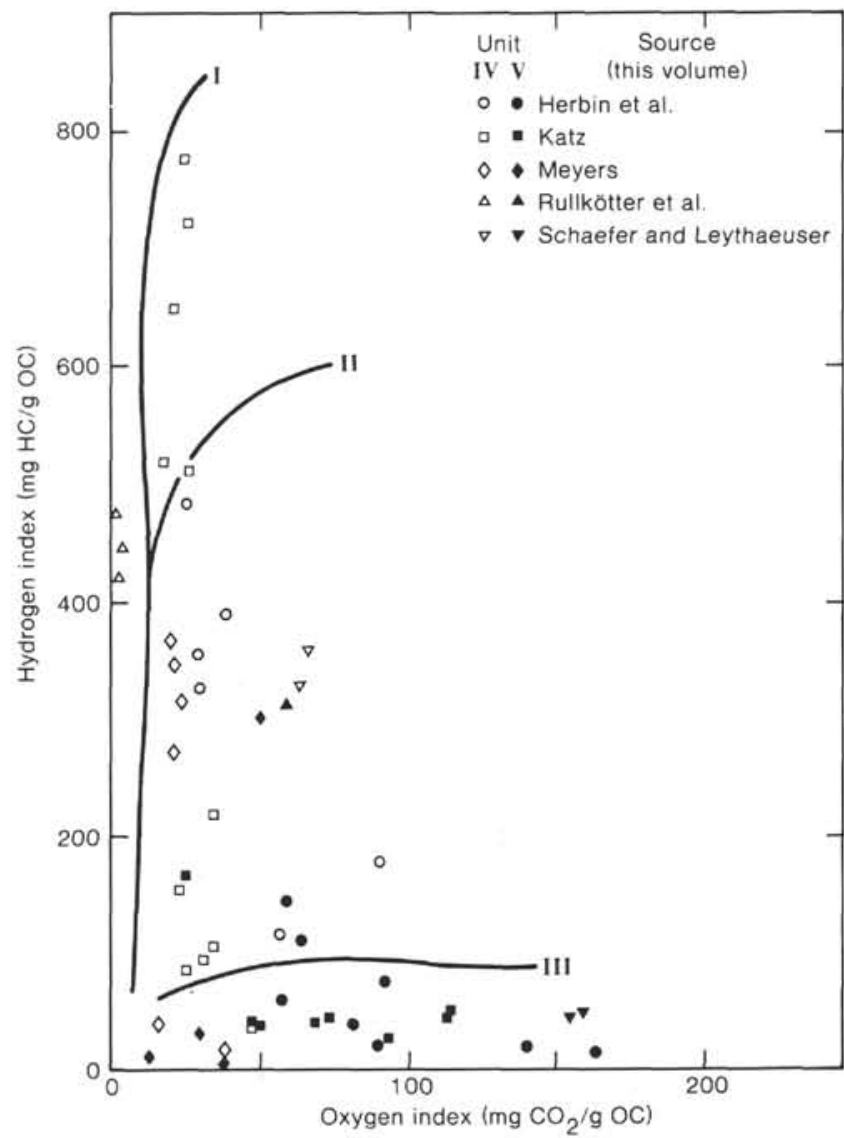

Figure 19. Summary of Rock-Eval analyses of samples from lithostratigraphic Unit IV (Hatteras Formation) and Unit V (Blake-Bahama Formation) at Site 603 (from Meyers, Fig. 3, this volume). Cenomanian black shale samples from the Hatteras Formation generally have high hydrogen indices representative of type II kerogen; however, most samples from other parts of Unit IV and Unit V contain poorly preserved, oxidized, or nonmarine type III organic matter. $\mathrm{HC}=$ hydrocarbons, $\mathrm{OC}=$ organic carbon.

vided into four subunits based on the presence or absence of sand and biogenic silica.

Unit III: $56 \mathrm{~m}$ of upper Miocene glauconitic, biosiliceous silty claystone, sand, and conglomerate. In this unit, the presence of sands is inferred from the drilling characteristics, as recovery was poor (only $7.2 \mathrm{~m}$ total core was recovered from $55.6 \mathrm{~m}$ of Unit III drilled in Hole 604). It was the downhole caving of these "suit-

Figure 18. Schematic diagram to depict depositional history in the vicinity of DSDP Site 603 (oceanic basin, right) and along the adjacent shelf (Baltimore Canyon Trough area, left) during Early Cretaceous times. This interpretation is based in part on recent commercial drilling results along the shelf margin reefal bank (RB) trend (see text). Turbidite depositional model adopted from Sarti and von Rad (Fig. 8, this volume). In sequence, the stages depicted illustrate the following events: A. Progradation and then aggradation of the reefal bank culminates in a reef "drowning" event by Valanginian times. B. Valanginian regression promotes submarine dissection of the reefal bank, perhaps breaching the reef to allow the passage of mud and sand turbidites to the deep sea. C. in spite of rising sea levels, deltas prograde rapidly across the shelf during the Hauterivian-Barremian in response to uplift and strong erosion in the hinterland; immature clastics accumulate in the shelf basin; siliciclastics overstep and bypass the defunct reefal bank and feed (sometimes directly from the delta front) the lower fan channel-levee complex in the oceanic basin. D. Major (Type 1) eustatic sea-level drop (base Vail Cycle LZB4.1) causes erosion that bevels the immature Neocomian clastic wedge out to top of the buried shelf edge reefal bank; the resulting massive, large-volume, sand-rich turbidites deposit thick, extensive channel-detached sand lobes in the oceanic basin. E. Transgression and rising sea level trap clastics on the inner shelf of the still subsiding basin; thick Aptian "blanket-like" carbonates (shelf-margin carbonate shoals) cover the shelf edge, but sustained transgression shifts the locus of carbonate deposition from the deep sea to the shelves and the epeiric seas; only carbonate-free fine clastics continue to accumulate in the oceanic basin. 


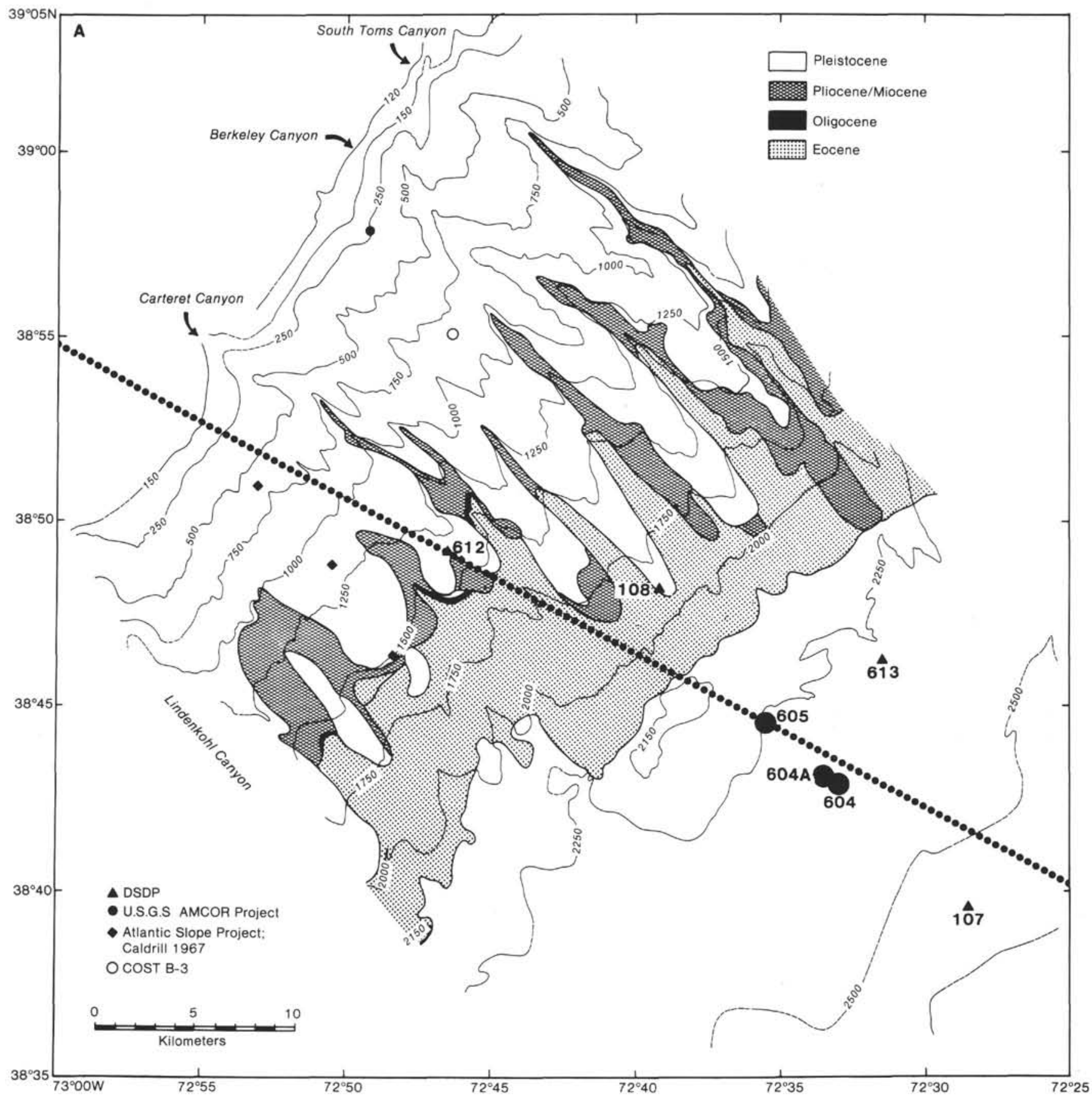

Figure 20. A. Geologic map of outcropping Tertiary strata on the New Jersey slope (after Robb, Hampson, Kirby et al., 1981; Robb, Hampson, and Twichell, 1981), showing locations of Leg 93 Sites 604, 605, other neighboring drill holes, and U.S.G.S. line 25 (dotted line). Note particularly the extensive Eocene outcrop belt. B. Location of U.S.G.S. lines 25,34 , and other seismic lines through the study area. Proposed drill site NJ-4 also shown.

case" sands ${ }^{4}$ that forced the abandonment of both holes attempted at this site (see "Operations" of Site 604 chapter). The conglomerates contain rounded quartz pebbles up to $1 \mathrm{~cm}$ long, clasts of claystone, chalk, and lime-

4 "Suitcase" sands: a sea-going driller's term used to denote loose and caving sands that cause such an impediment to drilling (usually preventing rotation and raising or lowering of the pipe) as to induce one to pack one's suitcase and abandon the drill site by the most expeditious and practical means available (fide Mr. Glen Foss, June 10, 1984). stone up to $10 \mathrm{~cm}$ in diameter, and rare shell fragments. Elsewhere in the unit are found exotic blocks of Eocene nannofossil chalk up to $50 \mathrm{~cm}$ thick. These and the conglomerates appear to represent debris flows, whereas some of the sands could be turbiditic. Further details of these debris flows are given below.

Lithologic units penetrated at Site 605 between 0 and $816.7 \mathrm{~m}$ are depicted in Figures 22 and 23 (see also Table 4). In descending order they are: 


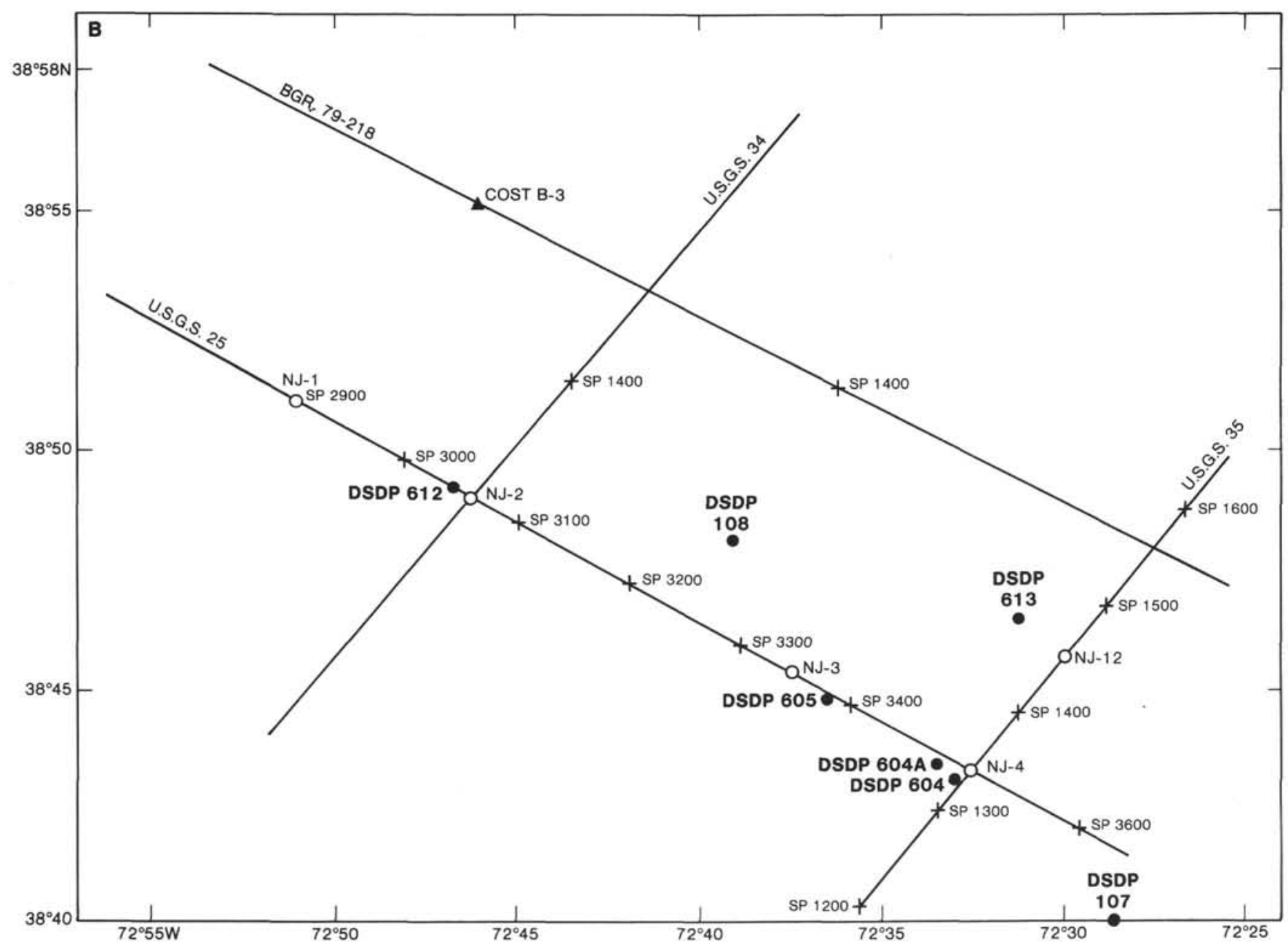

Figure 20 (continued).

Unit IA: $198 \mathrm{~m}$ of Pleistocene gray silt-rich clay.

Unit IB: Pleistocene green biosiliceous and calcareous clay. This $24-\mathrm{cm}$ unit is separated by a disconformity from the underlying unit and contains some reworked siliceous microfossils from that unit.

Unit II: $151 \mathrm{~m}$ of middle to lower Eocene biosiliceous nannofossil chalk rich in foraminifers, radiolarians, and diatoms.

Unit III: $214 \mathrm{~m}$ of lower Eocene greenish gray nannofossil limestone with varying amounts of foraminifers and calcified radiolarians.

Unit IV: $177 \mathrm{~m}$ of upper Paleocene dark greenish gray clayey nannofossil-foraminiferal limestone (marl).

Unit V: $76 \mathrm{~m}$ of lower Paleocene to upper Maestrichtian olive gray, clayey nannofossil-foraminiferal limestone.

All of the Paleogene to Maestrichtian units are strongly bioturbated. Preservation of trace fossils is excellent and several examples of whole Zoophycos burrows are present. The preservation of siliceous and calcareous microfossils is generally good in Unit II (except for foraminifers), poor in Unit III, and much improved in Units IV and V. Recovery was excellent throughout most of the section, particularly in the long $(200 \mathrm{~m})$ Paleocene interval.

\section{Maestrichtian-Eocene Depositional History, Site 605}

The oldest sediment cored at Sites 604 and 605 was upper Maestrichtian clayey limestone (Hole 605, Subunit VB). The terrigenous silt content of this material is quite low, averaging about $3 \%$, whereas the carbonate content is high, usually greater than $60 \%$ (the remainder being mostly clay minerals). It contains only trace amounts of glauconite. We had penetrated but only partially recovered (because the core fractured; see Fig. 24) a reasonably complete Cretaceous/Tertiary boundary sequence in an expanded section. At the contact, the basal Cenozoic foraminiferal Guembelitria cretacea Zone (P0) and the coccolith Cruciplacolithus primus Subzone (CP1a) overlie the foraminiferal Abathomphalus mayaroensis and coccolith Nephrolithus frequens zones, whereas the lower Danian foraminiferal Zone Pla ("Globigerina" eugubi$n a)$ has not been found in this fragmented portion of the core (Smit and van Kempen; Saint-Marc; Lang and Wise; all this volume). At that level there is no visual lithologic difference between the Maestrichtian and the lower Paleocene section which, on the other hand, is disconformably overlain by an unusually thick upper $\mathrm{Pa}$ leocene section. 


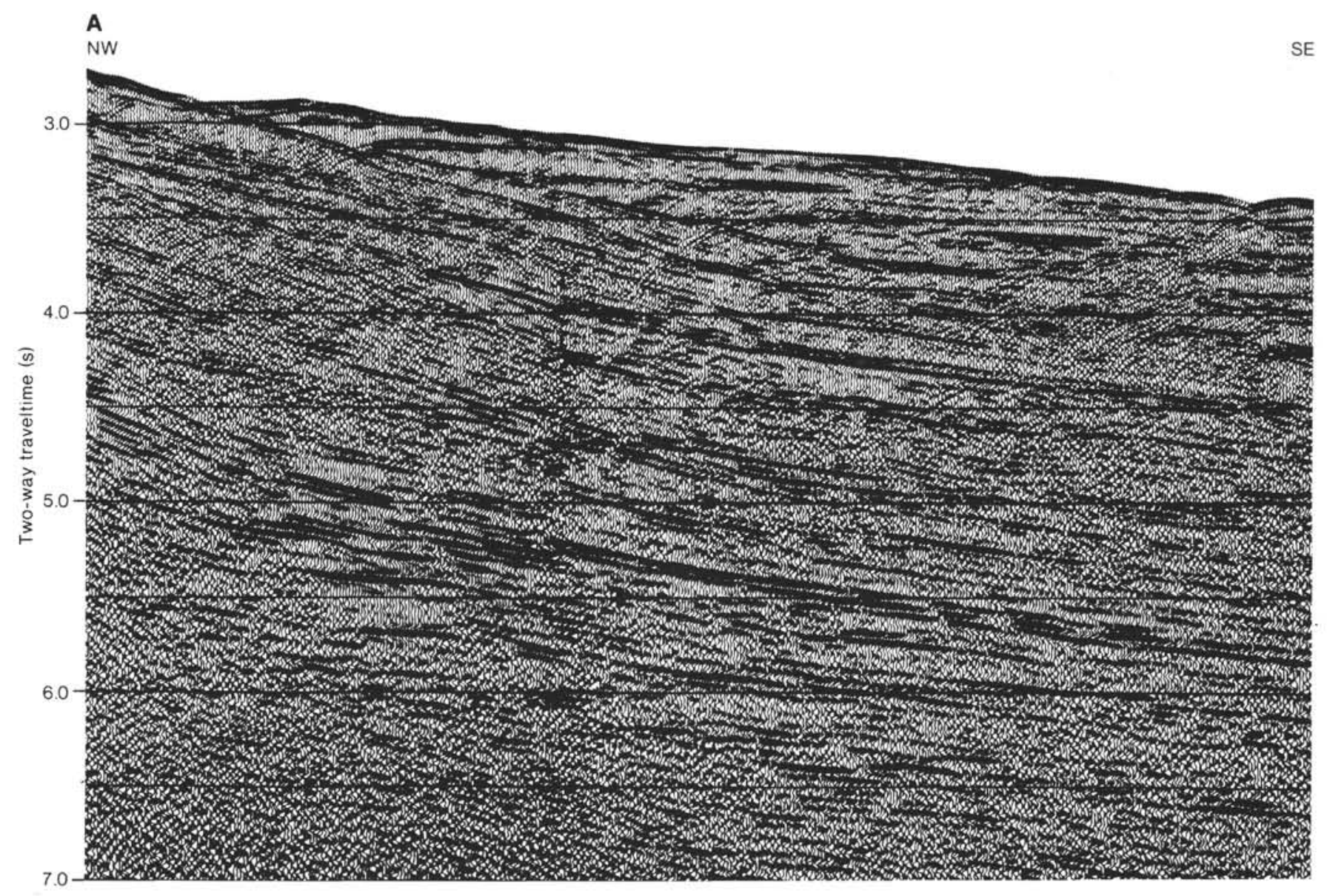

Figure 21. Original profile (A) and line drawing (B) after multichannel seismic reflection profile U.S.G.S. Line 25 . Leg 93 holes and nearby DSDP Site 107 are shown. $\mathrm{Pl}=$ Pleistocene, $\mathrm{U} \mathrm{Mi}=$ upper Miocene, $\mathrm{E}=$ Eocene, $\mathrm{P}=$ Paleocene, $\mathrm{Ma}=$ Maestrichtian. Reflection horizons (sequence boundaries) indicated to the left and right. Circled arabic number is local seismostratigraphic unit. B is after van Hinte et al. (1985b); for a different interpretation, see Site 604/605 chapter, this volume.

Unlike all but the uppermost $(45 \mathrm{~cm})$ Maestrichtian limestone below them, the earliest Danian sediments (Subunit VA) show an anomalously high percentage of terrigenous silt (15-20\%; see Fig. 23) and glauconite (2-4\%). Assuming that these micaceous silts and glauconites are land- and shelf-derived, Wise et al. (1986) suggested that hypotheses regarding their origins might include:

1. A terminal Cretaceous extraterrestrial impact (Alvarez et al., 1980; Smit and Hertogen, 1980) which may have induced exceptionally strong current-wave activity (tsunami), an explanation which would also account for the deep-water, current-bedded $\mathrm{K} / \mathrm{T}$ sand with spherules at Site 603 (Fig. 8A). The effects of such an impact would have decimated plant life, thereby increasing hinterland erosion and terrigenous riverine output; hence the continued high detrital content of Subunit VA.

2. Strong current erosion along the outer continental shelf, which would also account in part for a well-documented upper Maestrichtian-Eocene hiatus there (see Olsson, 1980, fig. 2).

3. Coincidental outbuilding of some local delta ( $R$. K. Olsson, personal communication, 1984; R. E. Sheridan, personal communication, 1984).

These hypotheses can be further considered in light of the synthesis by Olsson and Wise (this volume), who correlate the Maestrichtian-Paleogene sequence at Site 605 with formations of the adjacent New Jersey coastal plain (Fig. 25). They note that Cores 605-66 to -55 correlate with the homogeneous unit of glauconitized fecal pellets on land called the Hornerstown Formation, which crosses the $\mathrm{K} / \mathrm{T}$ boundary with no discernible physical break. As these beds are traced into the subsurface, they become more clayey and contain minor amounts of silt. To the south the Hornerstown is replaced by the Paleocene sands of the Brightseat Formation (Maryland). At Site 605 , minor amounts of silts reappear upsection in Cores $605-56$ to -46 (Fig. 23); these correlate with the glauconitic Vincentown sand of the coastal plain. In the subsurface, the Vincentown grades into a quartzose silt facies; therefore it appears that some of the silt and glauconite was deposited through normal depositional process as far out as Site 605. By analogy, one might conclude that similar processes account for the quartzose silts in the Danian Cores 66 to 64 at Site 605 , which would be the subsurface equivalents of the Brightseat Formation (Olsson and Wise, this volume).

Unfortunately, continuous physical correlation of Danian strata between Site 605 and the coastal plain is impossible because erosional disconformities on the middle and outer shelf intervene (Fig. 26). Olsson and Wise 


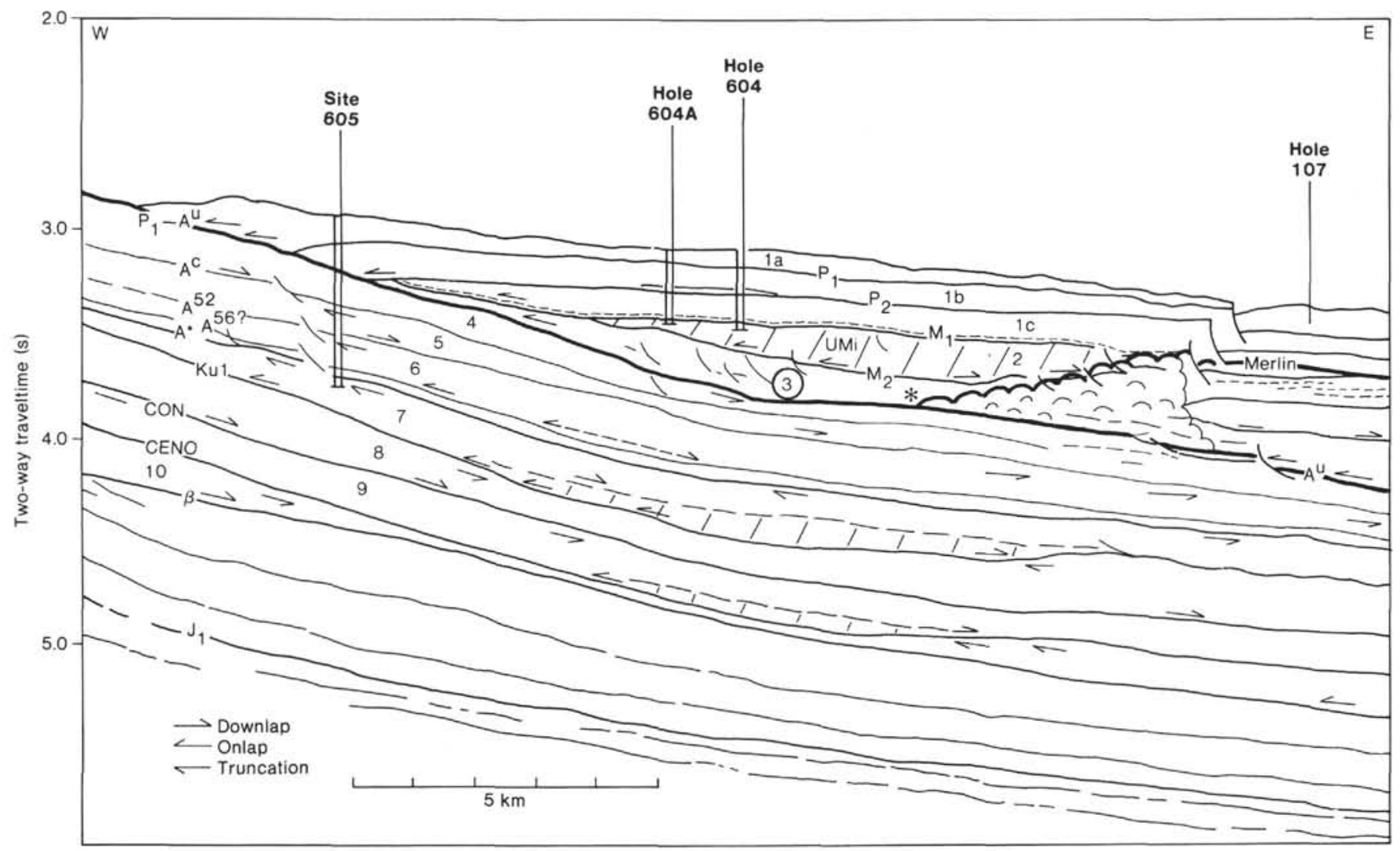

Figure 21 (continued).

(this volume) attribute this pattern of east coast sequential unconformities (their ECSU) to the action of a southward-flowing current that moved on and off the middle and outer shelf in response to sea-level changes. It was apparently most active during the Paleocene, a time of generally low sea levels.

The most profound of these Paleocene disconformities is recorded in both the coastal plain and in the first section of Core 605-64, where a sharp lithologic break (Fig. 27) coincides with hiatuses in the paleomagnetic, nannofossil, and possibly the foraminiferal sequences ${ }^{5}$ (Fig. 28). It also coincides with a strongly reflective seismic reflection horizon labeled $A^{*}$ in Figure 6 . The top of this hiatus corresponds with the base of Vail Cycle TP2.1 as calibrated by Vail et al. (1980), or with the base of Cycle TA1.3 as recalibrated by Haq et al. (in press). This latter is the lowest of two Type 1 Vail sequence boundaries that fall close to the lower/upper Paleocene boundary.

Surprisingly, at Site 605 we do not see evidence of the second of these Type 1 sequence boundaries (base of $\mathrm{Cy}$ cle TA2.1 as recalibrated by $\mathrm{Haq}$ et al., in press), which corresponds to the most profound drop on their matching eustatic sea-level curve. If a disconformity were present at that level in our cores, planktonic foraminiferal Zone P3b and most of nannofossil Zone CP4 would be missing (according to the Cenozoic Cycle Chart of Haq et

\footnotetext{
${ }^{5}$ Saint-Marc (this volume) assigns Sample $605-64-2,90-92 \mathrm{~cm}$ to the Morozovella uncinata Zone ( $\mathrm{P} 2)$ based on a form identified in his range chart as $M$. $\mathrm{cf}$. uncinata. We disregarded this age determination in constructing Figure 28 (as did Olsson and Wise in Fig. 25).
}

al., in press), but both are well represented at both Site 604 and in the New Jersey coastal plain (Saint-Marc; Lang and Wise; Olsson and Wise; all this volume). Our data in this case, therefore, seem to fit better the calibration given by Vail et al. (1980) rather than by Haq et al. (in press).

Regardless of exactly where near the lower/upper Paleocene boundary the disconformity in Section 604-64-1 is correlated, it is most important to note that this disconformity is not at the $\mathrm{K} / \mathrm{T}$ boundary. Thus, this highly reflective surface seen in seismic profiles along the shelf, slope, and upper rise of this margin cannot be used to mark the top of the Cretaceous.

In general, the Maestrichtian-Eocene sequence (lithologic Units II to V) is heavily bioturbated (Wetzel, this volume), indicating a steady input of nutrients (either via surface productivity or terrestrial influx) into the sediments. Sedimentation rates based on calcareous nannofossil datums through the Paleocene are exceedingly high (Danian $=11 \mathrm{~m} / \mathrm{m} . \mathrm{y} . ;$ middle Paleocene $=67 \mathrm{~m} / \mathrm{m} . \mathrm{y}$.$) ,$ although hiatuses and condensed intervals are present, as indicated in Figure 29. Based on data from DSDP, Hay et al. (1981) calculated average Paleocene sedimentation rates for the world ocean at less than $5 \mathrm{~m} / \mathrm{m}$.y. The high rates for the remarkably long Paleocene section at Site 605 are attributed to its continental margin site of deposition, which is favorably located well above the carbonate compensation depth and close to sources of fine-grained clastic sediment.

An apparent disconformity marked by a slight change and a physical and lithologic break in Section 605-44-5 


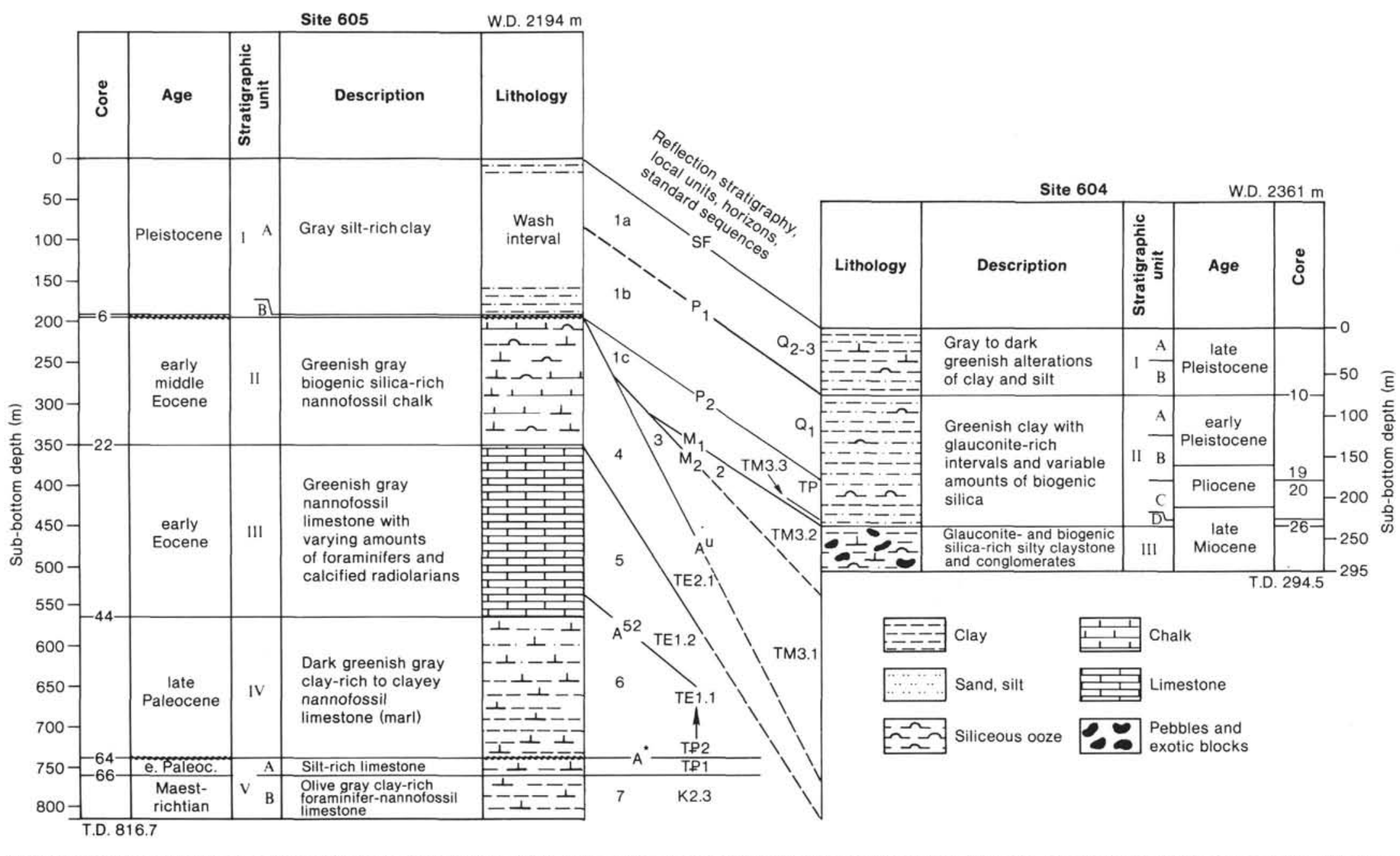

Figure 22. Stratigraphic summary of Sites 604 and 605 (Holes 604, 604A, 605). Units I to III and I to V are local lithostratigraphic units. Standard seismic sequence notation after Vail et al. (1980); for a different correlation of seismostratigraphic Units 2 and 3, see Site 604/605 chapter, this volume. 


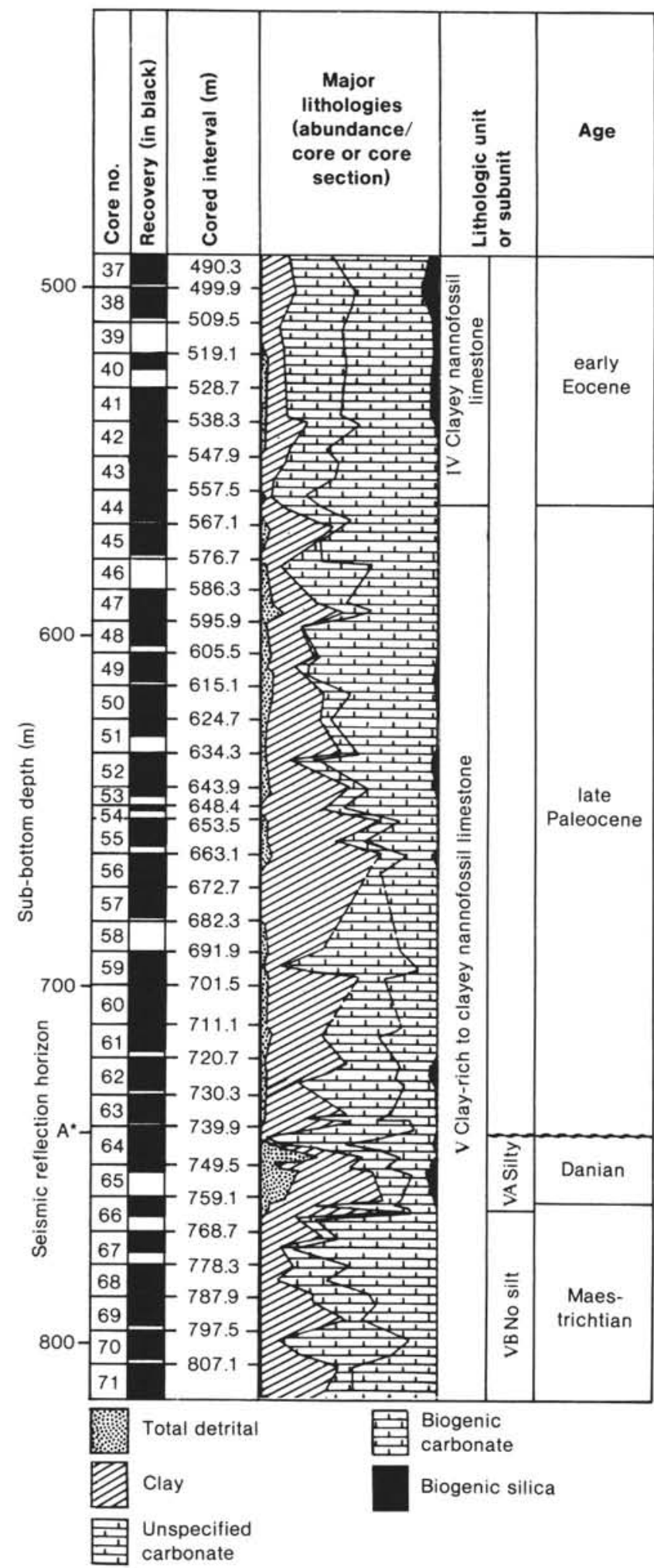

Figure 23. Lithologies, lithologic units, and ages for the Maestrichtian to lower Eocene section cored in Hole 605 (Cores 37 to 71, lithologic Units IV and V). Note that the high detrital content (terrigenous micaceous-rich silts) of Subunit VA begins near the Cretaceous/Tertiary boundary. A disconformity correlated with seismic reflection Horizon $\mathrm{A}^{*}$ (or $\mathrm{A}^{*}$ ?; see Olsson and Wise, this volume) separates Danian from upper Paleocene sediments. (arrow, Fig. 30) marks the Paleocene/Eocene boundary (Saint-Marc, this volume) as well as the contact between lithostratigraphic Units IV and III. After a condensed interval through the lowest Eocene nannofossil Zone CP9 (Fig. 29), sedimentation rates through the lower to middle Eocene average $37 \mathrm{~m} / \mathrm{m} . \mathrm{y}$.

Marl-limestone cycles (shown by faint to distinct color banding) are well developed in the Paleocene and lower Eocene lithostratigraphic Units IV and III, especially in Cores 605-51 to -55, and 605-58 to -62 (Site 604/605 chapter, this volume). Since carbonate dissolution at this shallow site would not have been a factor in the genesis of these cycles, their cause could have been (1) fluctuations in carbonate input related to productivity or (2) fluctuations in the input of terrigenous clay which dilute the background of continuous carbonate sedimentation (because of fluctuations in sea level, climate, etc.). Another type of cyclicity is manifested in Cores 605-33 to 35 and in Core $605-40$, where intensely bioturbated and faintly laminated undisturbed horizons alternate. These cycles may represent fluctuations in bottom-water oxygen content (Site 604/605 chapter, this volume).

Preservation of biosiliceous material improves dramatically at the lithostratigraphic Unit III/Unit II contact, as shown by the sharp increase in diatoms, radiolarians, silicoflagellates, ebridians, and siliceous sponge spicules (Gombos; McCartney; McCartney and Wise; all this volume). This change marks the diagenetic boundary responsible for seismic reflection Horizon $\mathrm{A}^{\mathrm{c}}$ (Tucholke and Mountain, 1979), below which the biosiliceous material has been largely converted to opal-CT to form porcellanite through a process described by many authors (for example, Wise and Weaver, 1974).

The marked increase in biosiliceous material could be attributed to an increase in plankton productivity. Sedimentation rates, however, do not change dramatically through the Eocene section of Hole 605 (Fig. 29). Thus, there appears to have been only a shift in the balance between siliceous and calcareous plankton productivity in favor of the siliceous groups, probably in response to upwelling, perhaps associated with the incursion of a cool current from the north (ancestral Labrador current?).

A most interesting discovery was a vitreous ash layer, 2 to $5 \mathrm{~cm}$ thick, of rhyolitic to rhyodacitic composition, in Sample 605-21-2, 145-147 cm; it is also found at the same stratigraphic level in DSDP Hole 613, some $8 \mathrm{~km}$ to the northeast (Fig. 20). Von Rad and Kreuzer (this volume) report a minimum $\mathrm{K} / \mathrm{Ar}$ age of $45 \mathrm{Ma}$ for the glass shards. The sample from Hole 605 falls near the base of nannofossil Zone CP13a (Lang and Wise, this volume), which ranges from $48.8-50.0 \mathrm{Ma}$ according to Berggren et al. (1985) or from 46.4-47.8 Ma according to Haq et al. (in press). Von Rad and Kreuzer (this volume) speculate that the ash might represent windblown tephra from a subaerial eruption on the island of Bermuda.

A recent report of a younger ash (nannofossil Zone NP16-17) from the Castle Hayne Formation of North Carolina (Thayer et al., 1985), however, opens up the possibility of a source to the south (Gibson and Towe, 1971 ) or to the southwest from the North American con- 


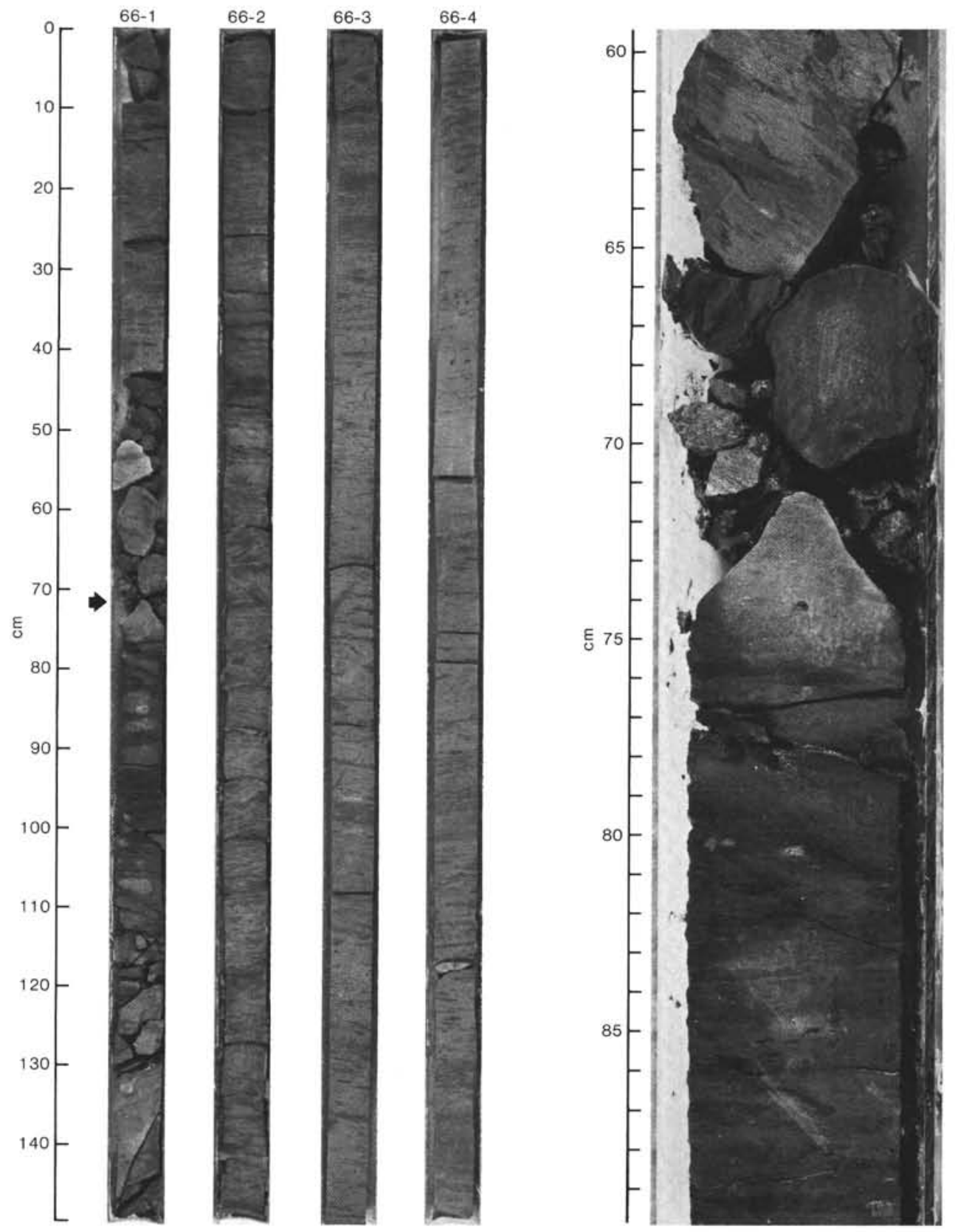

Figure 24. Core 605-66 showing shattered core at the Cretaceous/Tertiary boundary (arrow left, enlargement right). Note absence of appreciable change in shade (color) or in bioturbation pattern either side of the boundary. There is, however, an increase in silt content above the boundary (see Fig. 23).

tinent, either of which would be more consistent with prevaling wind patterns than a source at Bermuda. The most likely known source for the ash at Sites 604 and 605 would be the region around Monterey, Virginia (Highlands County) where Fullagar and Bottino (1969) dated light-gray, porphyritic, albite felsite dikes and sills at 46.9 $\pm 1.1 \mathrm{Ma}$ and $47.2 \pm 1.3 \mathrm{Ma}$. These dates correspond to a standardized "Western" age of about $48 \mathrm{Ma}$ (Harland et al. 1982, appendix 1), which falls well within the range of the nannofossil dates quoted above. The intrusive rocks themselves are occasionally vesicular and contain scattered albite phenocrysts; their ground mass exhibits a well-developed trachytic texture (Fullagar and Bottino, 1969). Gray and Gottfried (1986) classify them as transitional rocks (intermediate between alkalic and tholeiitic) of mantle origin, typical of those emplaced in rift environments.

Not seen in our Leg 93 cores is explicit evidence of a major canyon-cutting event that is believed to have occurred in response to a sea-level drop near the beginning of the middle Eocene (base of Vail Supercycle TA3 [Cycle TA3.1] as calibrated by Haq et al., in press). Site 605 was apparently located over an intercanyon region that received essentially continuous sedimentation. Slumped material associated with this event was drilled at nearby Site 613 during Leg 95 (Poag, 1985a), and Mountain and Tucholke (1985, fig. 8-21B) illustrate what they believe is an Eocene canyon at least $400 \mathrm{~m}$ deep and $6 \mathrm{~km}$ 


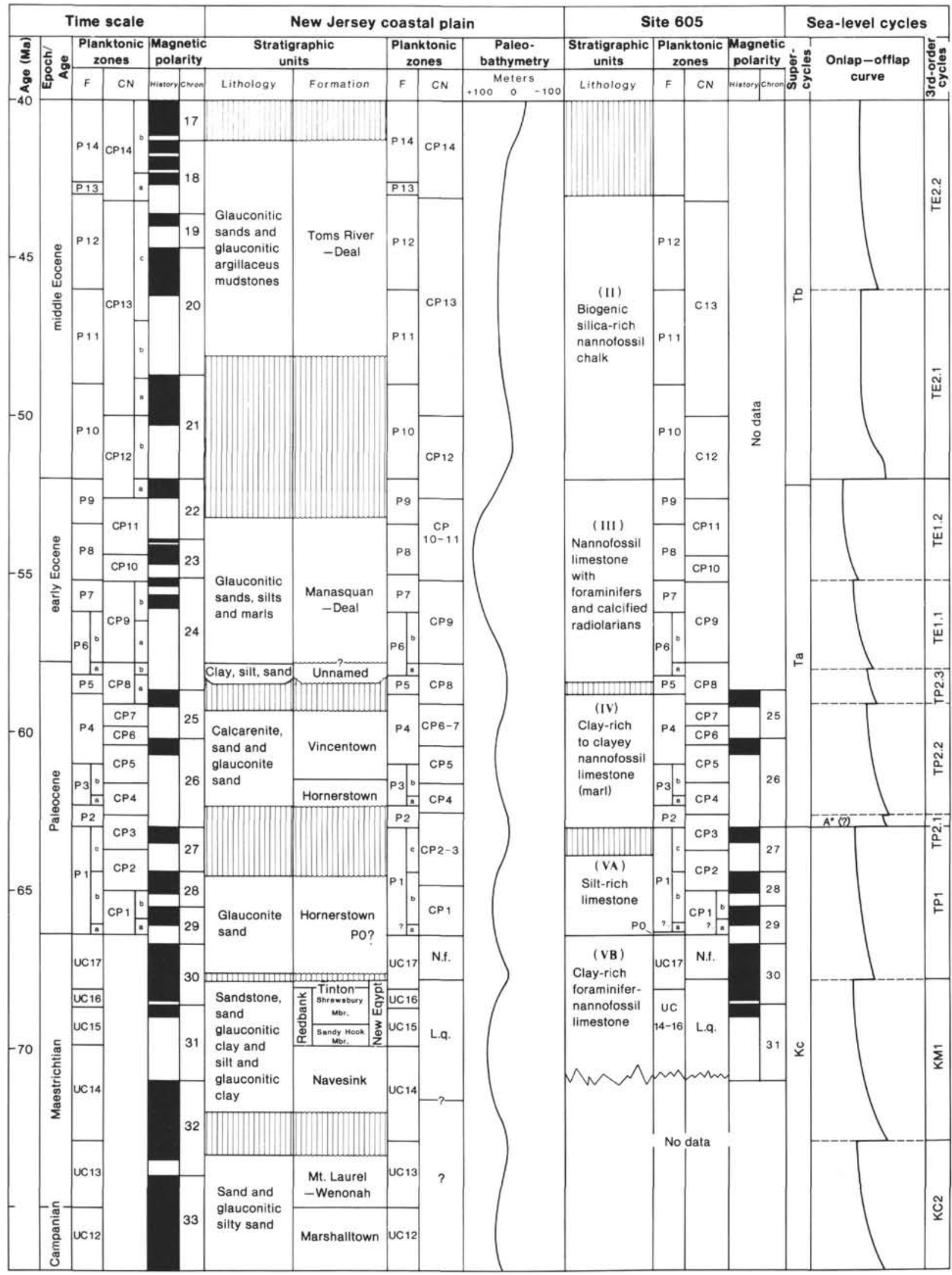

Figure 25. Comparison of New Jersey coastal plain stratigraphy, biostratigraphy, and paleobathymetry with lithostratigraphy, biostratigraphy, and magnetostratigraphy of Site 605 (from Olsson and Wise, Fig. 4, this volume). Magnetostratigraphy after Bruins et al. (Fig. 7, this volume). Onlap-offlap curve for Tertiary sequences after Vail et al. (1977). Cretaceous sequences derived from New Jersey coastal plain (Olsson, 1980). N.f. = Nephrolithus frequens, L.q. = Lithraphidites quadratus. 


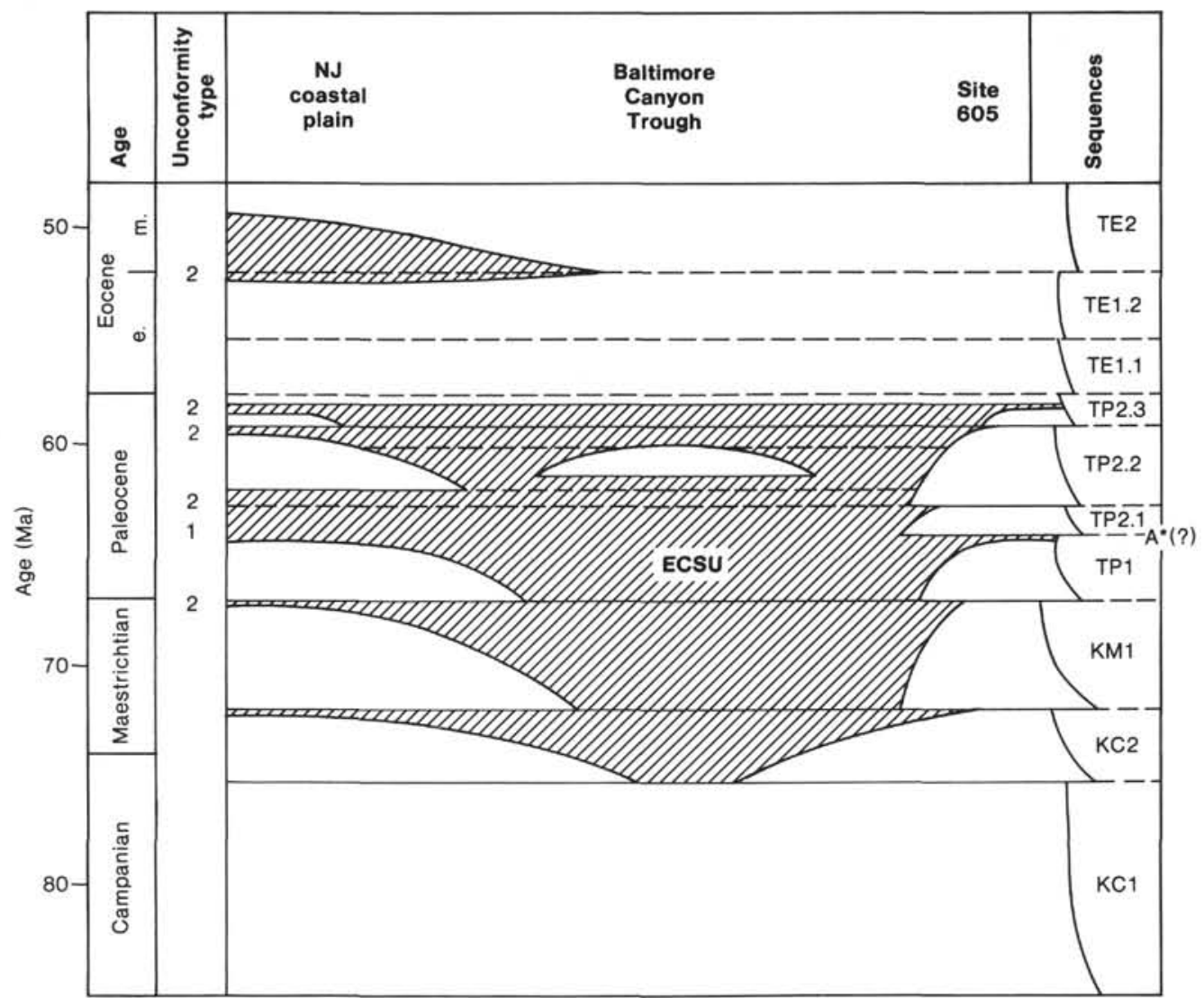

Figure 26. Model showing the relationship of the East Coast Sequential Unconformity (ECSU) along the Baltimore Canyon Trough to the stratigraphic sequences of DSDP Site 605 and the New Jersey Coastal Plain (from Olsson and Wise, Fig. 15, this volume).

wide on U.S.G.S. multichannel seismic line 34 , which crosses line 25 along strike near DSDP Site 612 (Fig. 20B) in our study area.

\section{Oligocene Erosional Events}

Because drilling problems at Site 604 terminated both holes there within the upper Miocene debris-flow sequence, DSDP Leg 93 obtained no direct information on the Oligocene-middle Miocene interval. Reworked upper Eocene and middle Miocene microfossils in the upper Miocene sediments of Site 604 indicate that those units are present in the area. No reworked Oligocene material was identified, and at Site 605 these sediments are missing. There, Pleistocene sediments are separated from the middle Eocene by a pronounced disconformity (Frontispiece, Fig. F), which can be traced as the coalesced $\mathrm{A}^{\mathrm{u}}$ seismic reflection horizon, and which surfaces at the base of the Eocene outcrop belt mapped by Robb and his colleagues (Robb, Hampson, Kirby, et al., 1981; Robb, Hampson, and Twitchell, 1981; Fig. 20A). Upper Eocene, Oligocene, and lower or middle Miocene sediments have been intersected by various slope and shelf wells above the Eocene outcrop belt as described by Poag (1985a) and Mountain and Tucholke (1985). These include DSDP Leg 95 Hole 612 and the COST B-2 and B-3 wells. The relationships among some of these wells and the Eocene outcrop belt are shown in Figure 31, where they have been projected onto U.S.G.S. line 25 .
Better insight into the late Eocene and Oligocene history of our study area is provided by the seismic analysis of Mountain and Tucholke (1985, fig. 8-25), who illustrate the stratigraphic relationships along the slope and rise created by two major Oligocene erosional events (see also Miller et al., 1985). The first is an earliest Oligocene erosional event associated with seismic reflection Horizon $\mathrm{A}^{\mathrm{u}}$, a relatively flat reflector widely traceable throughout the North American Basin. This corresponds to a Type I sequence boundary and moderate eustatic sea-level drop at the base of Vail Cycle TA4.4 (Haq et al., in press). It also corresponds to the development of the psychrosphere, which Wise et al. (1986) link to the buildup of a moderate-sized ice sheet on the interior of the Antarctic continent (see also Miller et al., 1985, and references therein).

The second Oligocene disconformity is labeled reflector mO (ie., middle Oligocene) by Miller et al. (1985). It corresponds to a more profound glacio-eustatic event (base of Vail Supercycle Set TEJAS B [Cycle TB1.1] of Haq et al., in press) that induced extensive canyon cutting in our study area and elsewhere along the slope and rise. In our study area, the disconformity associated with this reflector is coalesced with Horizon $\mathrm{A}^{\mathrm{u}}$.

As we still lack direct evidence on the nature and extent of Oligocene to middle Miocene sediments along the upper rise, we cannot determine the full extent to which these Oligocene erosional events sculptured and 

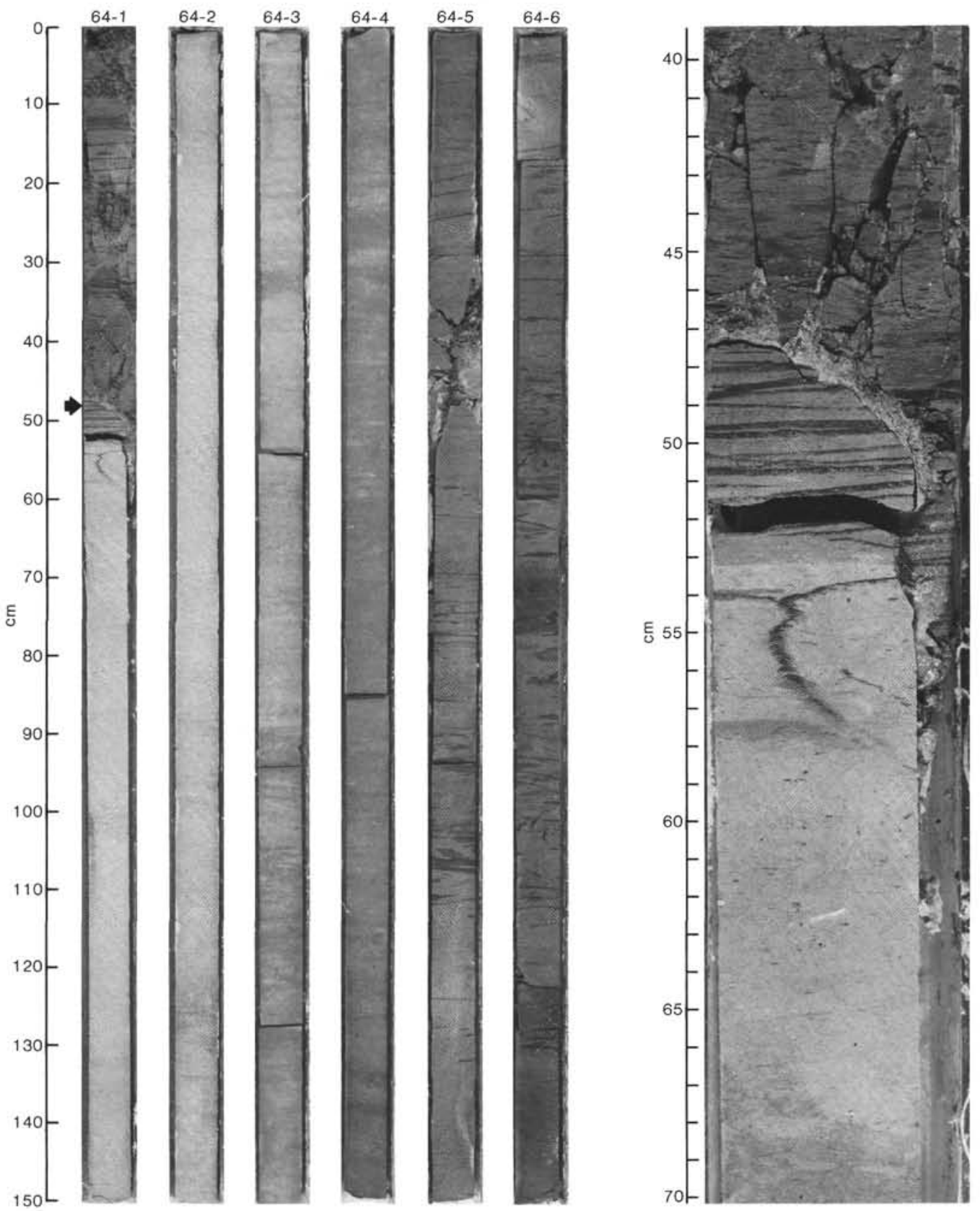

Figure 27. Paleocene Core 605-64 showing a lithologic break in Section 1 (arrow left, enlargement right) which marks a $2.6 \mathrm{~m}$.y. hiatus that separates Danian sediments below (lower nannofossil Zone CP2) from upper Paleocene sediments above (upper Zone CP3). This break also corresponds with the Vail et al. (1980) Cycle TP2.1 low stand and with seismic reflection Horizon $\mathrm{A}^{*}$ (or $\mathrm{A}^{*}$ ?) (see Fig. 28). The change in shade to a lighter color below the break corresponds to a change from a clayey limestone above to a rather pure foraminiferal limestone below. Note also change in bioturbation pattern either side of the break.

removed sediment along the slope near our Leg 93 sites. Nor can we specify when and for how long Eocene strata lay exposed in outcrop as seen today. Schlee et al. (1976) and Grow (1980), however, estimate that the continental shelf edge retreated landward up to $30 \mathrm{~km}$ as a result of erosion begun during the mid-Tertiary.

\section{Late Miocene Erosion and Debris Flows at Site 604}

Leg 93 did obtain direct evidence on the character of upper Miocene sediments on the upper rise. Although unexpected, the debris flows cored at Site 604 were one of the most interesting, informative, and still challenging discoveries made during the cruise.

\section{Debris-Flow Anatomy}

The best recovery was in Core 604-26, which penetrated the top of the upper Miocene debris flows beginning at Section 2, $46 \mathrm{~cm}$ (arrows, Fig. 32A; white arrowhead, Fig. 32B; see also Frontispiece Figure E for color enlargements of these lithologies). The portion of Core 


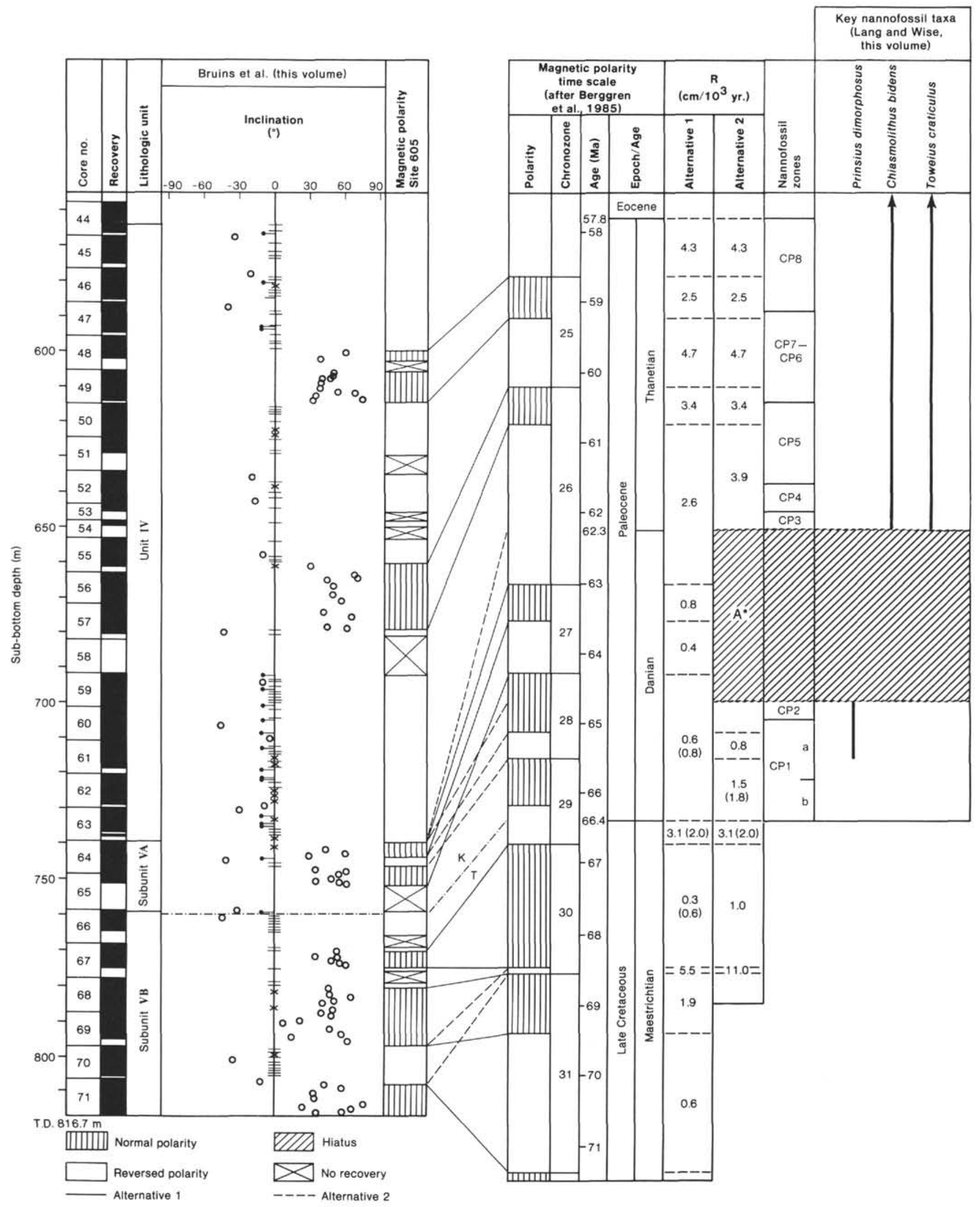

Figure 28. Correlation of disconformity shown in Figure 27 with magnetostratigraphy (Bruins et al., Fig. 7, this volume) and nannofossil biostratigraphy (Lang and Wise, this volume). Alternative 2 for the magnetostratigraphic correlation is preferred here. Position of $\mathrm{A}^{*}$ (or $\mathrm{A}^{*}$ ?) also shown on Figures 23, 25, and 27. 


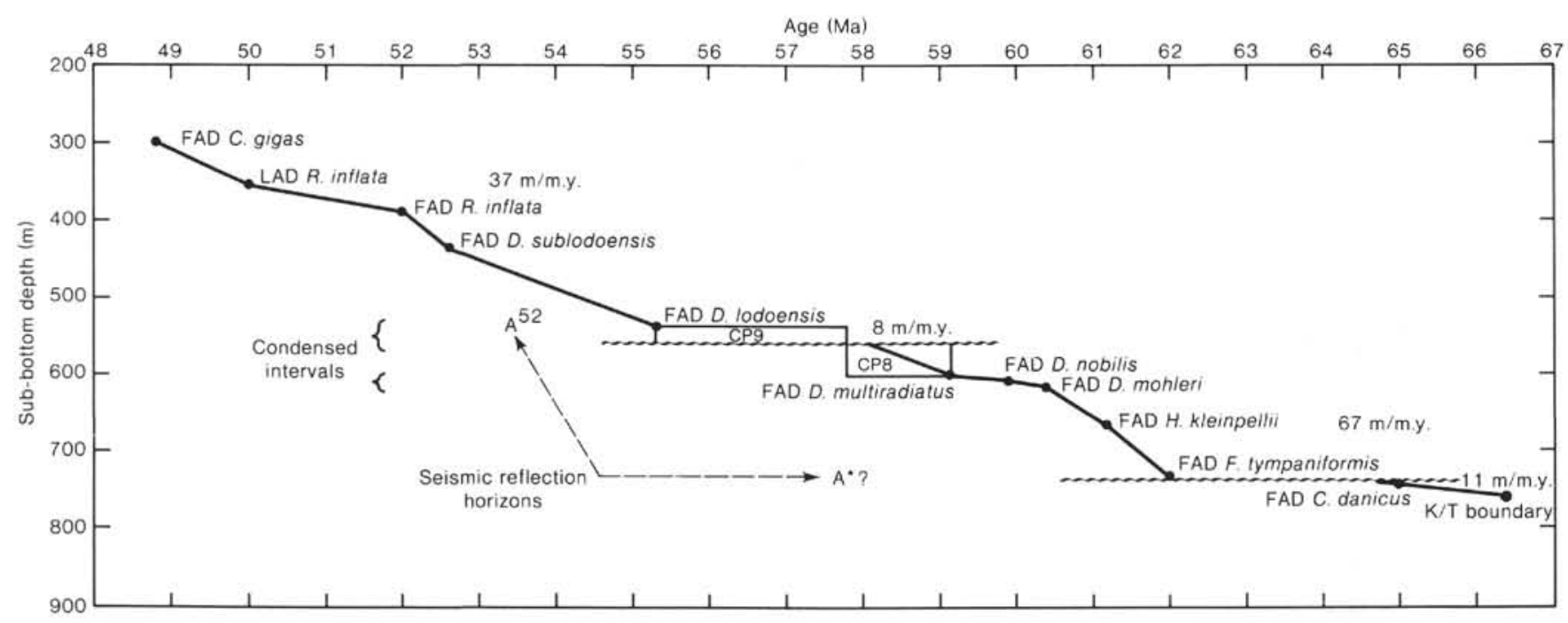

Figure 29. Sedimentation rate diagram for Hole 605 based on nannofossil datums (from Lang and Wise, Fig. 10, this volume). Hiatuses and correlations with seismic reflection Horizons $\mathrm{A}^{52}$ and $\mathrm{A}^{*}$ ? indicated. Condensed intervals indicated by braces. Eocene datums are from Applegate and Wise (this volume).

604-26 below the top of the debris flows (Fig. 32A) contains a wide assortment of pebbles, cobbles, and shell debris scattered in a claystone or siltstone matrix sometimes quite rich in siliceous microfossils (Fig. 32B). A number of the pebbles and a portion of a bivalve shell are shown in Figure 33A. The bivalve appears to be a clam displaced from shallow water. Pebbles "b" and "c" are mafic in composition as is pebble "e," which is a peridotite composed of coarse-grained olivine. Pebble " $\mathrm{f}$ " is a Paleozoic chert fragment, $3 \mathrm{~cm}$ in length, which contains recognizable portions of trilobite exoskeletons and what appears to be a brachiopod (Fig. 33B). This highly angular pebble (which was sectioned on one side by the saw used to split the core) was probably derived from lower Paleozoic strata of the Appalachians (C. Schreiber, personal communication, 1984), whereas the peridotite probably came from the structural core of the same mountain belt.

Cobbles in Cores 604-26, -27, and -30 represent a variety of ages ranging from early Eocene to middle and late Miocene. Those from Samples 604-26-3, 52-54 cm (Fig. 32B) and 604-27-1, 23-25 cm (Fig 33D) are middle Miocene or younger, both having been derived from shallower water. For instance, the first sample mentioned, seen in thin section in Figure 33C, contains shallow-water benthic foraminifers characteristic of outer neritic environments (cibicidids, hanzawaids, etc.; fide $\mathrm{K}$. G. Miller in Wise et al., 1986). Particularly interesting, however, is the fact that the highly angular clastic grains (predominantly quartz and glauconite) are supported by a fine-grained carbonate matrix. This would indicate an original aragonite mud environment in the near shore; however, no such environment is known from the Miocene of the New Jersey coastal plain, probably because most of the middle to upper Miocene section is missing in this particular area. Missing, therefore, are those strata which would have represented the peak of the middle Miocene transgression (according to the Vail et al., 1980, coastal onlap curve), when Miocene climates should have been most equitable, the most likely time to expect aragonite mud production this far north (R. K. Olsson, personal communication, 1984). Thus, the Miocene cobbles in the debris flow at Site 604 may be the only specimens available which represent that former shallow-marine environment.

The displaced blocks of Eocene carbonate are similar to lithologies drilled at Sites 108 and 605; their sources were, therefore, probably much closer to Site 604 than those of the Miocene cobbles. Today in our study area the broad belt of middle to upper Eocene strata that crop out along the lower slope (Figs. 20 and 31) provides a source from which blocks or slabs of the material can be shed onto the rise below. The most spectacular example of such a slab in our Miocene section is the $50-\mathrm{cm}$ block of middle Eocene limestone recovered in Section 604-27-1 (Fig. 32A), the internal coherence of which was disturbed by drilling. A detailed view of the core immediately above this block reveals the complex nature of the debris flows (Fig. 33D). Laminae containing sediments or microfossils of quite different ages, compositions, and consistencies are closely juxtaposed.

Perhaps the most important feature shown in Figure 33D is the cut-and-fill channel indicated by arrow "CH." This erosional surface marks the termination of one debris flow and the beginning of the next, a clear indication that more than one debris-flow event is represented in lithologic Unit III. Despite the minimum recovery in this unit, at least three separate debris flows could be distinguished on a tentative basis by the Leg 93 shipboard sedimentologists. This delineation of separate and distinguishable debris flows at Site 604 tells us that the debris flows within lithologic Unit III (local seismic reflection Unit 2) have a complex history; that our sample coverage through the interval drilled is incomplete; and that we penetrated only the uppermost portion of the unit. These complexities are sufficient to predict that paleontologic dating of the material will be difficult, and that tracing seismic horizons across this and similar dis- 

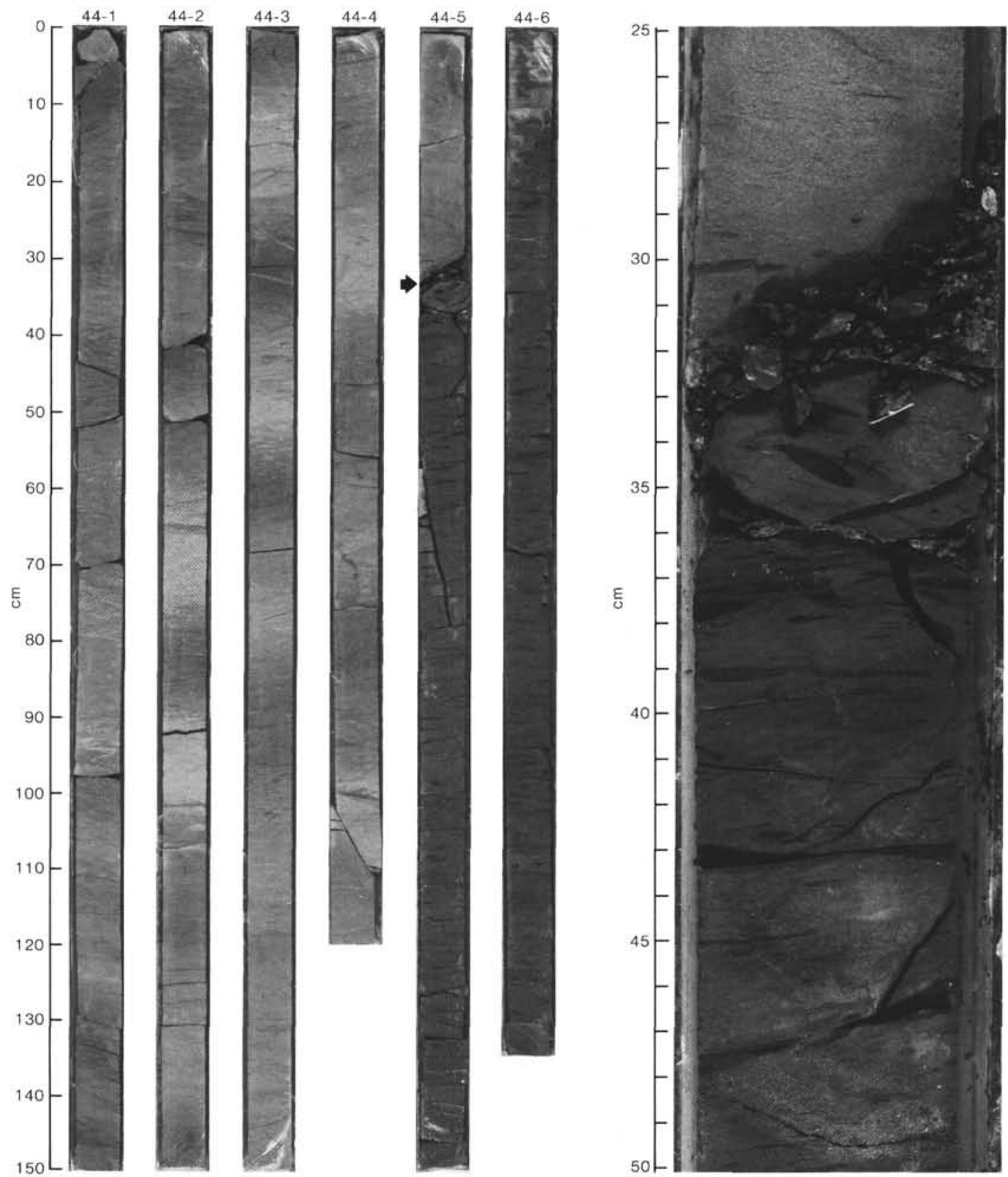

Figure 30. Core 605-44 showing break in core (arrow left, enlargement right) which may represent a disconformity at the Eocene/Paleocene boundary (Saint-Marc, this volume). Note change in shade (color) and bioturbation pattern either side of the break.

rupted packages of sediment along the upper rise will be even more challenging.

\section{Nannofossil Dates}

The dark claystones and siltstones that form the "matrix" between the larger clasts of the Hole 604 debris flows contain impoverished foraminiferal faunas which have not yielded definitive age dates (Site 604/605 chapter; Moullade; both this volume). Lang and Wise (this volume), however, have ventured nannofossil age determinations for these sediments on the tenuous assumption that the floras and sediments sampled are in situ, despite the pervasive background of reworked Eocene coccoliths present in all samples. Their dates are summarized here.

The sandy greenish gray clay immediately above the debris flows and those below the lithologic Unit II/III contact down to Sample 604-26-2, 110-112 cm contains no calcareous nannofossils, and could be as young as the Discoaster quinqueramus Zone (CN9, upper Tortonian-Messinian). On the other hand, those below the contact could be as old as the Discoaster neohamatus Zone (CN8, lower Tortonian) in keeping with the dates assigned to Samples 604-26-2, $145 \mathrm{~cm}$ through 604-27-1, $29-30 \mathrm{~cm}$. The lowest clays recovered in Core 3 at Hole $604 \mathrm{~A}$ are assigned to the same zone, but the core catcher 
contains an admixture of $\mathrm{CN} 8$ and very rare $\mathrm{CN} 9$ coccoliths (considered to be downhole contaminants). Planktonic foraminifers, however, have been dated in this core (see Site 604/605 chapter, this volume), and are assigned to $\mathrm{N} 17$ ( = CN9 in age).

For the remainder of Hole 604, recovery was meager (none in Core 604-29 and less than a meter of claystone in Core 604-30). Lang and Wise (this volume) assign the siltstones of Core 604-28 to the coccolith Discoaster hamatus Zone (CN7; both D. hamatus and Catinaster calyculus are present). Core 604B-30 is not well dated, and could be slightly older.

The debris flows sampled at Site 604 before drilling was terminated, therefore, fall (according to Lang and Wise, this volume) within nannofossil Zones CN7 and CN8, which Berggren et al. (1985) now correlate with the lower to mid Tortonian (upper Miocene) and assign an age of about 8.2 to $10.0 \mathrm{Ma}$. Haq et al. (in press) provide nearly identical ages for these zones. These dates suggest that if drilling had continued beyond Core 60430 , Hole 604 would shortly have penetrated middle Miocene strata, assuming a continuous sequence within local seismic reflection Unit 2.

\section{Interpretation from Seismic Stratigraphy}

The above interpretation conflicts with the seismic analysis by JEVH (Site 604/605 chapter, this volume), who notes that Hole 604 penetrated only a short distance into local seismic reflection Unit 2, which is characterized by a lens-shaped cross section with a flat top and a convex bottom. The disrupted onlap fill pattern may represent gravitite fill behind a slump mound (Figs. 21,31 ). It overlies local reflection Unit 3 , which is a complex bundle of irregularly lens-shaped reflection units that show contorted bedding and numerous small growth faults. The lower boundary of this unit is the erosional reflection Horizon $\mathrm{A}^{\mathrm{u}}$. At least portions of the unit are composed of slumps and slides.

Noting that Core 3 of Hole 604A contains upper Tortonian-Messinian planktonic foraminifers (mixed with predominantly lower Tortonian nannofossils), the junior author considers the entire debris-flow sequence drilled in both Holes 604 and 604A to be of the younger age, in which case the older nannofossil assemblages of Lang and Wise described in Hole 604, Cores 26 to 30, have all been reworked. Seismic reflection Unit 2, therefore, would likely be Messinian in age, whereas reflection Unit 3 would be Tortonian. ${ }^{6}$

It is possible that both the nannofossil and seismic interpretations are correct. The differences would be resolved if the sequence drilled in Hole 604 was itself a slumped yet internally coherent block of lower Tortonian sediment which had slid from atop the Eocene chalks updip during late Tortonian or Messianian times. In that case there could be more than one Tortonian section tel-

\footnotetext{
${ }^{6}$ The reader should not feel alarmed that such a disagreement could exist between the co-chief scientists of this cruise. This has happened before. In the previous instance (which in volved the timing of the Aptian eustatic sea-level drop), a bottle of Chateau de Blagnac from the vineyards surrounding JEVH's residence near Bordeaux was wagered against a boule SWW's Lafayette Vineyard's Florida Muscadine, one of Tallas wagee's fines. A similar and st. A similar and equally fair wager will cover the present difference of opinions until it is resolved.
}

escoped one over the other within seismic reflection Unit 2. The small fault and landward-dipping reflectors illustrated by Poag (1985a, fig. 9-3B) between shot points 3540 and 3560 along U.S.G.S. line 25 may indicate such slumping. If the mass movement occurred during Messinian times, this explanation would account for occasional mixing of Messinian and Tortonian sediments as might have occurred in Hole 604A, Core 3.

Final resolution of this difference of opinions between the authors of this paper will require additional detailed paleontologic study and seismic analysis beyond the scope of these Initial Reports. We dare say that debates of this nature will continue long after this volume is published, until a shipboard system is installed for continental margin drilling which will allow the successful penetration, with good recovery, of sandy debris-flow sequences such as those described here.

\section{The "Merlin Problem," Upper Rise}

Reflection Horizon Merlin is an oceanic seismic reflector described by Mountain and Tucholke (1985), who date it to around planktonic foraminiferal Zone N14 time. Muza and Wise (this volume; discussion to follow) believe the reflector can be reliably dated at Site 603 between 10.5 and about $9.5 \mathrm{Ma}$. Attempts have been made by various authors to trace this reflector to the upper rise. Because of the ambiguities in our present data, it could be correlated at a number of levels in the section at Hole 604 .

Three possibilities for correlating Horizon Merlin are illustrated on the sedimentation rate diagram for Site 604 in Figure 34 (adapted from Lang and Wise, this volume). Merlin could lie (a) at the base of our local seismic reflection Unit 3, where it would coalesce with reflection Horizon $\mathrm{A}^{\mathrm{u}}$ (Site 604/605 chapter, this volume); (b) at the base of our local seismic reflection Unit 2, where it would coincide with local reflection Horizon $\mathrm{M}_{2}$ (assuming a thick upper Miocene or telescoped and repeated Tortonian section; see Wise et al., 1986; Lang and Wise, this volume); alternatively, it may coalesce at this level with Horizon $\mathrm{A}^{\mathrm{u}}$ (Mountain and Tucholke, 1985; Poag, 1985a); or (c) near or within the base of the drilled section of Hole 604 (assuming a continuous, in situ sequence there not complicated by slumping). It is fair to point out that Horizon Merlin has not been mapped along the upper rise in exactly the same way in any two of the publications just cited.

\section{Initiation of Submarine Canyon Cutting}

The debris flows cored at Site 604 indicate an important episode of submarine canyon cutting along the outer shelf, slope, and possibly the upper rise. Because the lower bounding reflection horizon beneath the debris flow package $\left(\mathrm{M}_{2}\right.$; Fig. 34) was not penetrated and dated, we cannot say when this particular episode began. Recent interpretations of high-resolution U.S.G.S. seismic data by J. Farre and G. S. Mountain (in Wise et al., 1986), combined with preliminary DSDP Leg 95 drilling data published by Poag (1985a, figs. 9-2 and 9-4), suggest that this erosional event was initiated during the late middle Miocene, with debris flows continuing into 


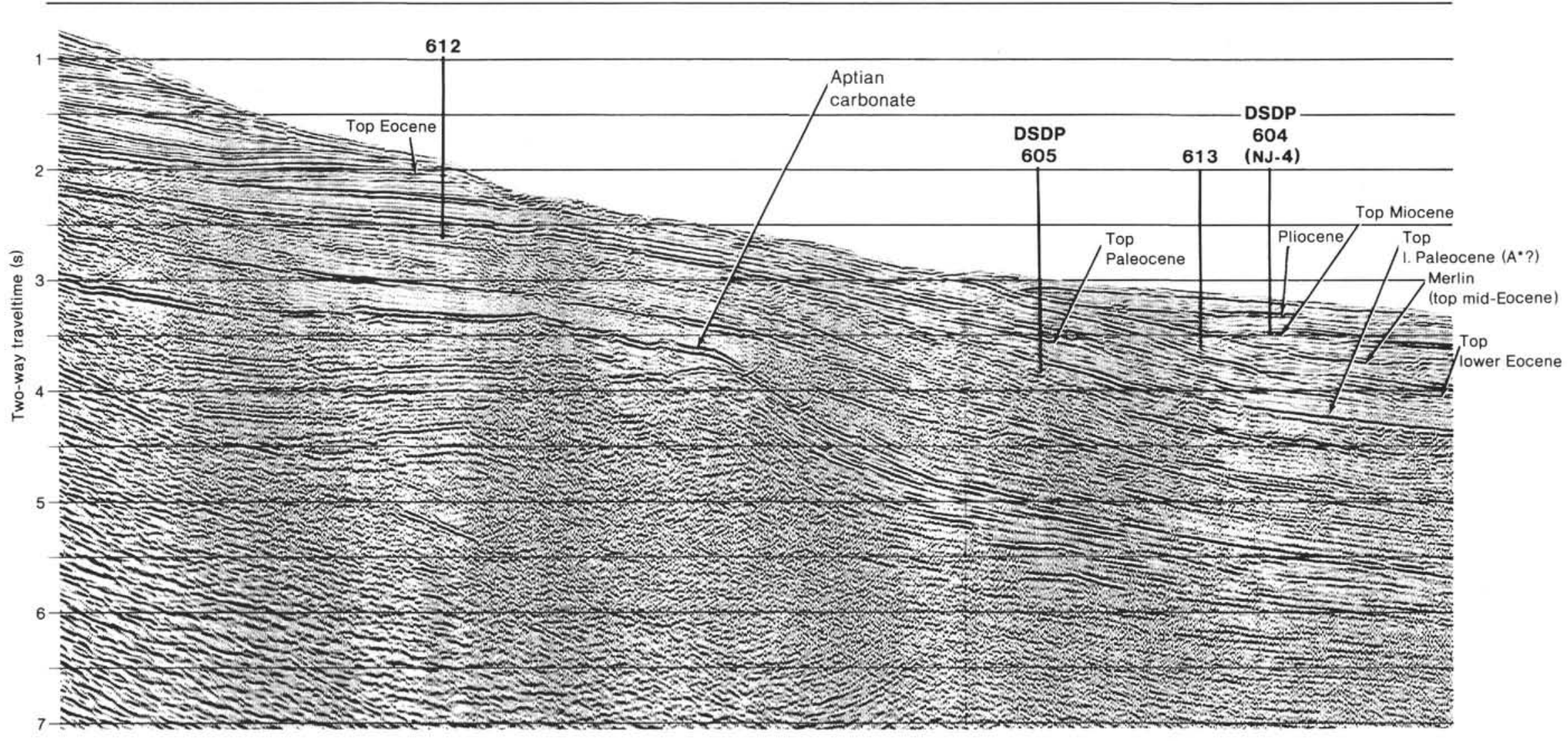




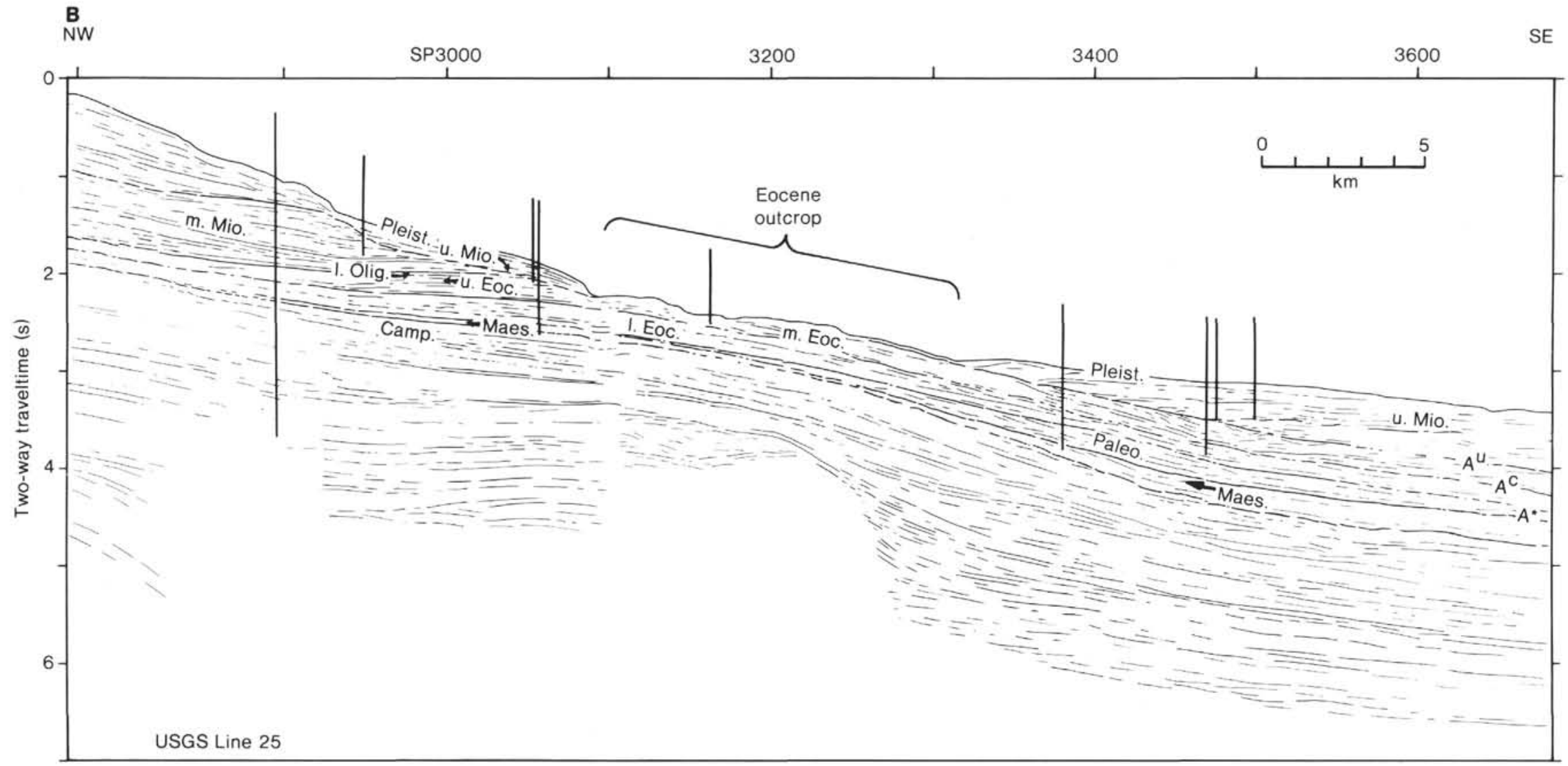

Figure 31. Original profile (A) and interpreted line drawing (B) of a segment of U.S.G.S. multichannel line 25 showing locations of DSDP Leg 93 Sites 604 , 605 , and other drill hole locations projected onto the line (B after Mountain, personal communication, 1986). See Figure 20 for location of line 25 and the drill holes and note on both Figures $20 \mathrm{~A}$ and 31 the location of the Eocene outcrop upslope from the Leg 93 drill sites. Aptian carbonate same as in Figure 18E. 

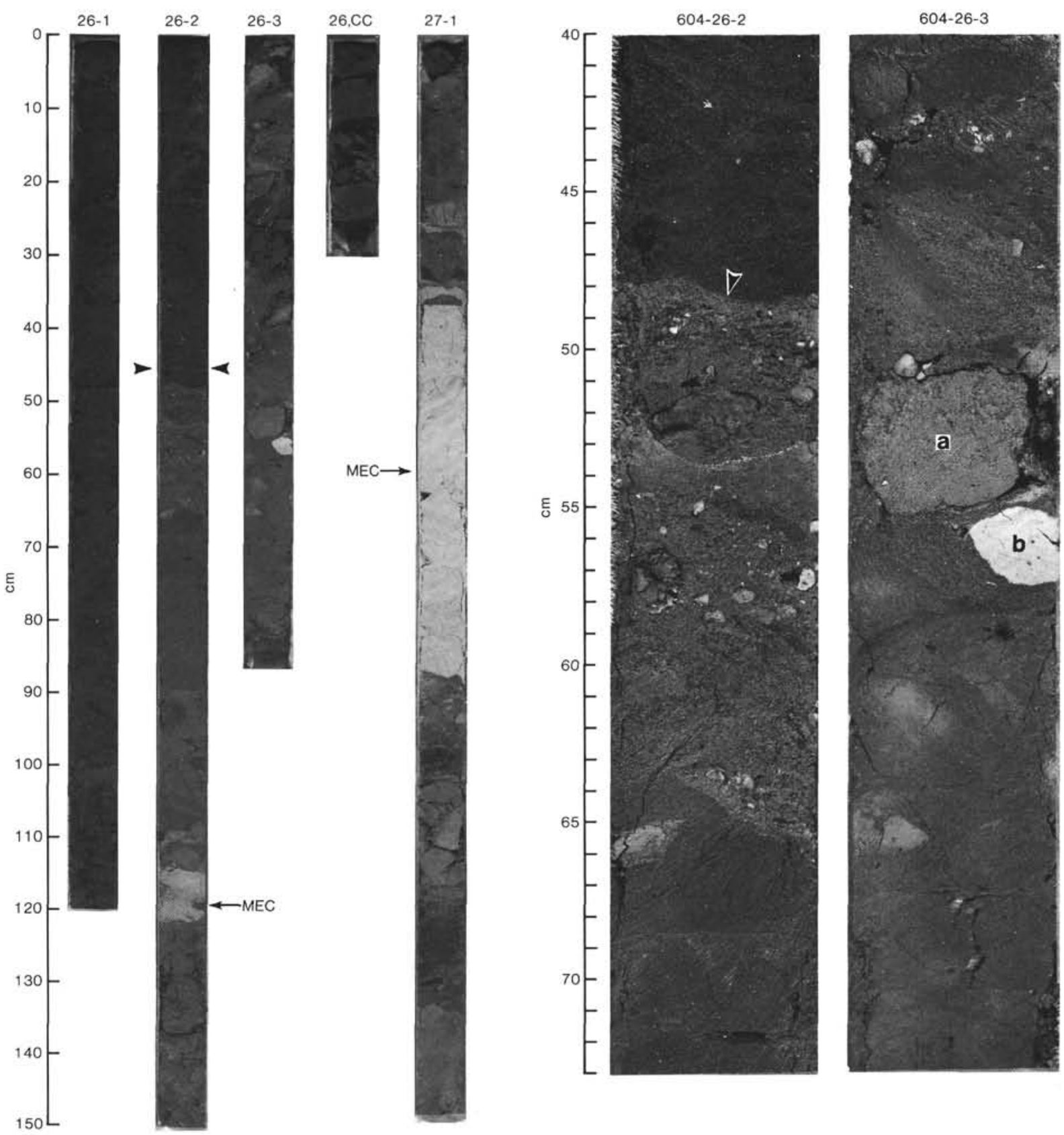

Figure 32. Cores 604-26 and -27 from the upper Miocene Unit III of Hole 604. A. The top of the youngest debris flow is indicated by the arrowheads at 604-26-2, $46 \mathrm{~cm}$. MEC = middle Eocene chalk. B. Details of upper Miocene debris flows in Core 604-26, Sections 2 and 3. The top of the youngest debris flow is marked by white arrowhead in Section 2. Note numerous pebbles in both sections and exotic cobble-sized clasts in Section 3. Clast "a" at 51 to $55 \mathrm{~cm}$ in Section 2 is middle Miocene or younger in age; clast "b" is Eocene chalk.

the late Miocene (11.3 to at least 8.2 Ma). A more definitive indication of when middle to late Miocene canyon cutting began in general would probably exist if Hole 604 had penetrated not just local seismic reflection Unit 2 , but reflection Unit 3 as well. This topic will be discussed further under "Neogene clastic sedimentation at Site 603. . . ."

\section{Paleoenvironmental Interpretation of the Debris Flows at Site 604}

In spite of the ambiguities in our data and the contrasting opinions expressed by the various authors who have examined the lithologic and seismic sections near Sites 604 and 605 , we offer the following comments on the paleoenvironmental significance of the debris-flow sequence. This interpretation is based on the senior author's view that the debris flows cored in Hole 604 represent a coherent block of Tortonian sediments deposited in stratigraphic sequence (whether that block of sediments is still in place or not).

The nannofossil correlations of Lang and Wise (this volume) suggest that the debris flows were emplaced largely during Vail Cycle TB3.1 of Haq et al. (in press). Vail Cycle TB3.1 was previously designated as Cycle TM3.1 

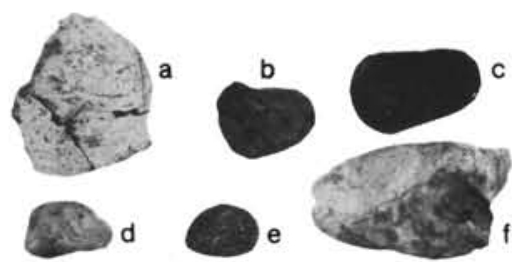

A
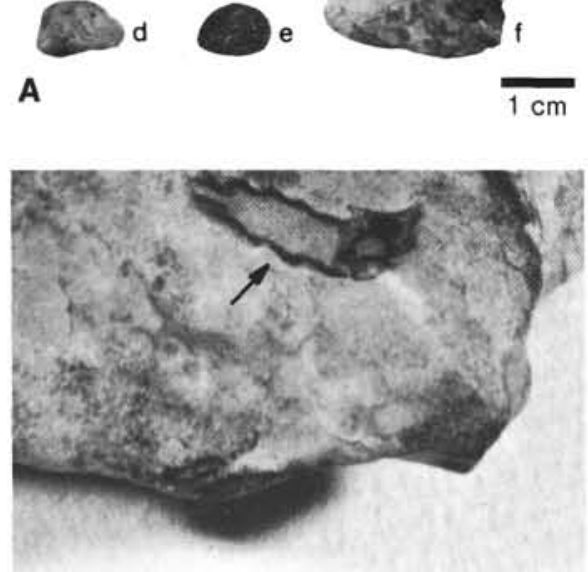

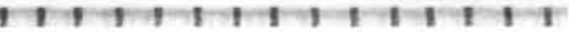

B
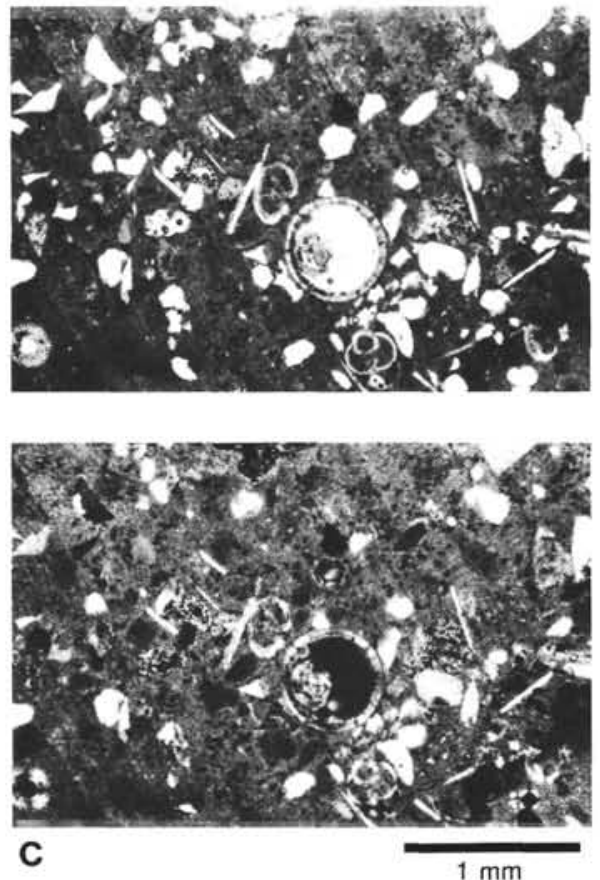

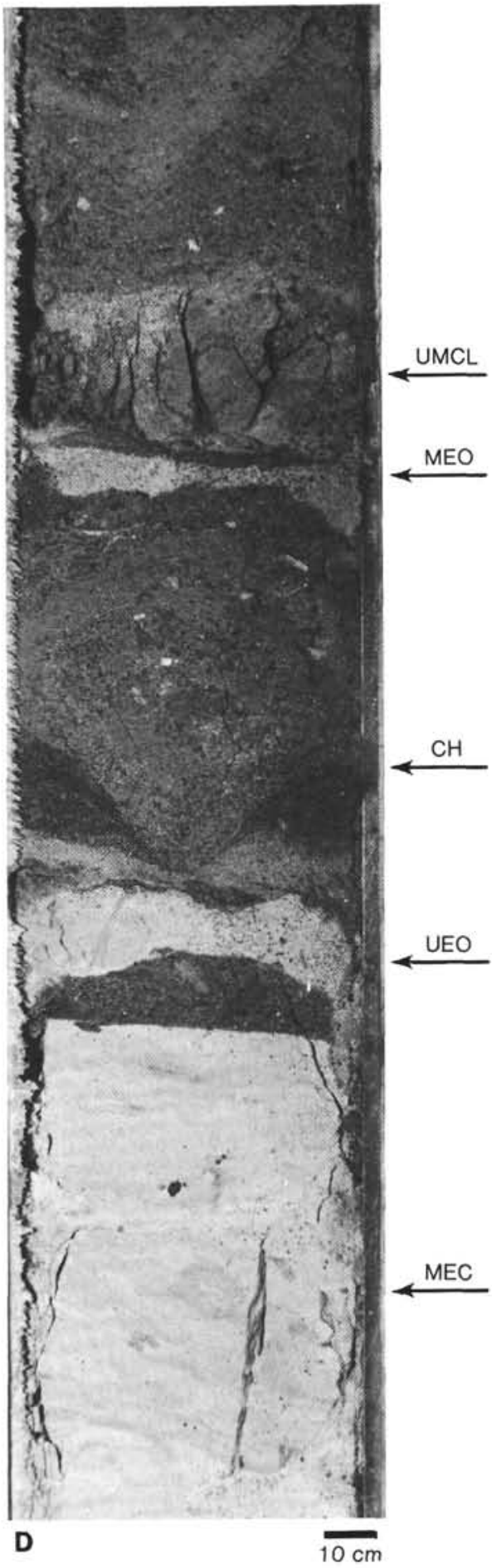

Figure 33. Further details of debris flows in Cores 604-26 and -27. A. Shell and pebbles from upper Miocene debris flows in Core 604-26: (a) clam shell $(604-26-3,16 \mathrm{~cm})$; (b, c) mafic pebbles $(604-26-2,109$ $110 \mathrm{~cm}$ ); (d) quartz pebble (604-26-2); (e) coarse-grained peridotite from 604-26-3, $18 \mathrm{~cm}$; (f) angular pebble of lower Paleozoic chert containing trilobite exoskeletons and a brachiopod $(604-26-3,12 \mathrm{~cm})$. B. Detail of brachiopod (arrow) in Paleozoic chert pebble (A [f] above). C. Thin section of middle (or upper) Miocene cobble ("a") shown in Figure 32B; 604-26-3, 52-54 cm. Note foraminiferal tests and highly angular clastic grains (quartz, glauconite, feldspars, and mica) supported by a fine-grained carbonate matrix. Original matrix thought to have been aragonite mud; top, transmitted light; bottom, cross-polarized light. D. Detail of the interval $604-27-1,17-46 \mathrm{~cm}$ from Figure 32 above showing (1) an erosional cut-and-fill channel $(\mathrm{CH})$ that marks the contact between two debris flows, and (2) juxtaposed sediments of various lithologies and ages overlying the 50-cm-thick slab of middle Eocene chalk. MEC = middle Eocene chalk; UEO = upper Eocene nannofossil ooze; $\mathrm{MEO}=$ middle Eocene nannofossil ooze; the dark lithologies are upper Miocene clastics (coccolith Zone CN8), including one large (2.5-cm thick) clast (UMCL) which contains relatively shallow water (upper bathyal) benthic foraminifers. 


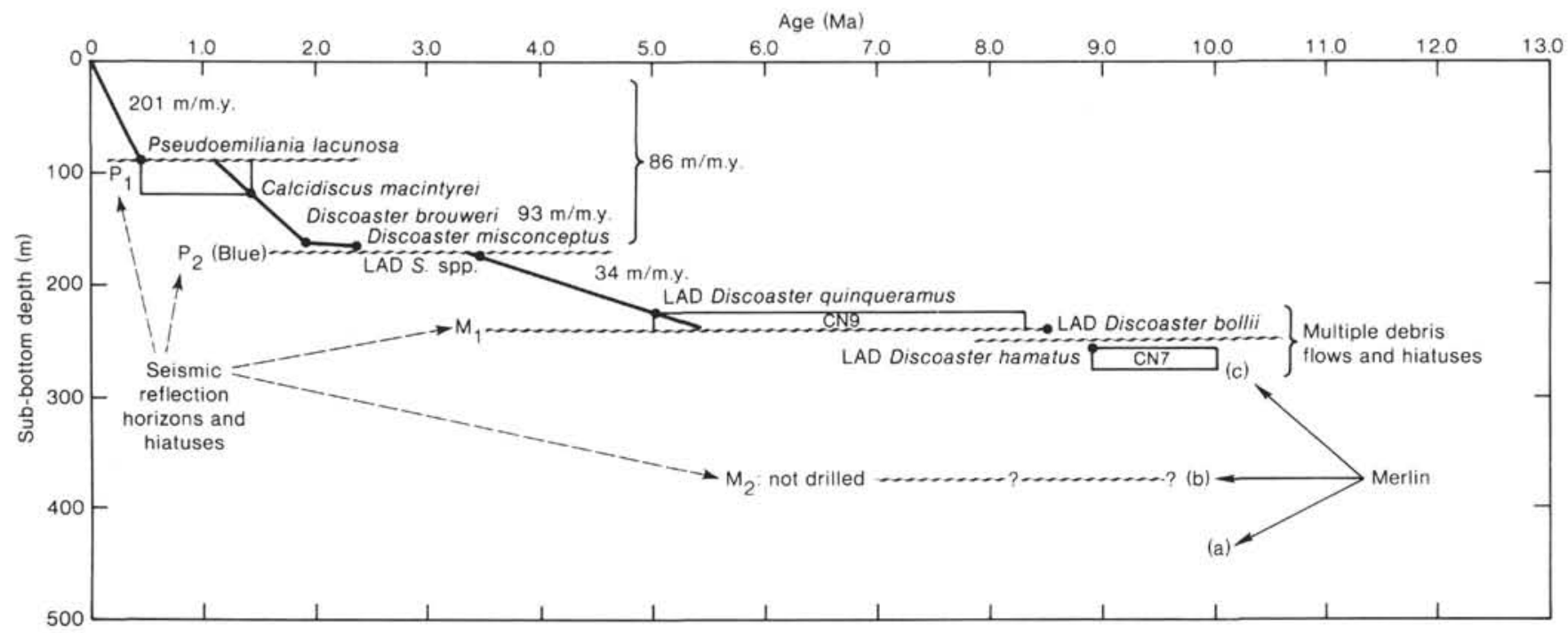

Figure 34. Sedimentation rate diagram for Hole 604 based on nannofossil datums (after Lang and Wise, Fig. 9, this volume). Hiatuses and correlations with local seismic reflection Horizons $\mathrm{P}_{1}, \mathrm{P}_{2}$, and $\mathrm{M}_{1}$ indicated; position of Horizon $\mathrm{M}_{2}$, which was not drilled, is estimated. Three possible solutions for the correlation of oceanic seismic reflection Horizon Merlin (Mountain and Tucholke, 1985) into the section at Hole 604 as discussed by various authors are indicated as follows: (a) Merlin coalesced with Horizon $\mathrm{A}^{\mathrm{u}}$ below our local seismic reflection Unit 3 (Site 604/605 chapter, this volume); (b) Merlin equivalent to local Horizon $\mathrm{M}_{2}$ and below our local reflection Unit 2 (Lang and Wise, this volume), or coalesced with Horizon $\mathrm{A}^{\mathrm{u}}$ below local reflection Unit 2 (Mountain and Tucholke, 1985; Wise et al., 1986, fig. 16; Poag, 1985a); (c) Merlin near or within the base of the drilled section at Hole 604 (see text, this chapter).

by Vail et al. (1977), who illustrated it as a sharp sea-level drop leading up to a low stand in the Messinian. Haq et al. (in press), now illustrate it as the low stand of the late Miocene (a Type 1 sequence boundary) at the base of their Supercycle TB3). It was this extreme low stand of sea level that caused a major episode of canyon cutting and generated the debris flows sampled at Site 604.

Deep erosion of the continent and the Appalachian chain during the early Tortonian is suggested by the metamorphic rock fragments carried out to the shelf edge, where deep canyons were cut into the outer shelf slope and probably a short distance out onto the rise. As the material bypassed the slope, sediment was removed from canyon walls and from the Eocene outcrop belt along the lower slope, all of this being deposited on the upper rise, which served as the primary depocenter for the coarser material. As seen at Site 604, chaotic debris flows containing the rock fragments cut away from the slope and canyon walls continued to maintain irregular and complicated patterns of accumulation through at least mid-Tortonian times (nannofossil Zone CN8). The debris flows had ended, however, before the end of the Miocene and of nannofossil Zone CN9 time (as dated in Sample 604-25-2, $110 \mathrm{~cm}$; Lang and Wise, this volume). Subsequently, glauconite-rich sands and occasional influxes of reworked Eocene calcareous materials continued to accumulate in much lesser but varying quantities through the Pleistocene.

As discussed by Wise et al. (1986; see also Muza et al.; Lang and Wise; both this volume), the emplacement of the debris flows sampled at Site 604 centered upon a time ( 10.5 to $8.2 \mathrm{Ma})$ when the effects of the late Miocene glaciations on the Antarctic continent were beginning to be felt in the more northerly reaches of the Southern Ocean. For the area northeast of the Falkland Pla- teau (near DSDP Site 513), Ciesielski and Weaver (1983) document a major abyssal erosional event which, they believe, occurred in the early late Miocene (prior to 9.5 or $10.0 \mathrm{Ma}$ ). This was followed by the initiation of ice rafting at 8.7 Ma; this, Ciesielski and Weaver (1983) consider, indicates the establishment of large Antarctic ice shelves. These in turn probably led for the first time to the formation of a grounded West Antarctic Ice Sheet (well after East Antarctic glaciation began at about 15 to $14 \mathrm{Ma}$ ). At this point, ice formation on Antarctica was at a maximum, not to be equaled or exceeded until the development of Northern Hemisphere continental glaciation during the Pliocene-Pleistocene. According to the record from the Southern Ocean, then, it was during the Tortonian that the greatest and most rapid drop in sea level should have occurred.

The Miocene glacial events on the Antarctic continent induced significant eustatic sea-level fluctuations. Upper Miocene sediments are essentially absent in offshore boreholes along the east coast of the United States (Poag, 1985a, fig. 6-2) and have not been identified in land outcrops of the coastal plain. During this time of lowered sea levels, the shoreline migrated toward the shelf break where rivers spilled their loads, and submarine canyons eroded headward to receive them. The lower Tortonian regression at the base of Vail Cycle TB3.1 was indeed profound, as is witnessed by the debris flows and turbidites that resulted from this period of deposition in an unstable shelf-edge environment.

Local seismic reflection Horizon $\mathrm{M}_{1}$ coincides with the sharp lithologic break at the top of the debris flows (Figs. 21, 22, and 32). The olive green claystone immediately above that (Fig. 32, Core 604-26) is diatomaceous and lacks calcareous nannoplankton, which are absent up through Sample 604-25-2, $110 \mathrm{~cm}$. These upper Tor- 
tonian(?) or Messinian(?) sediments may indicate upwelling in this area, perhaps related to incursions of a proto(?) Labrador Current system.

\section{Pliocene-Holocene Sedimentation, Site 604}

Glauconitic sands, shallow-water foraminifers and shell fragments, and occasional displaced Eocene material in lithostratigraphic Units I and II reflect further unstable sea-level and current conditions into the Pliocene and Pleistocene. These conditions are also manifested in changes in sedimentation rates, hiatuses, or disconformities.

Sedimentation rates in the early Pliocene were $34 \mathrm{~m} /$ m.y., but were nearly three times that in the late (glacial) Pliocene (Fig. 34). The Pliocene hiatus delineated in Figure 34 is correlative with local seismic reflection Horizon $\mathrm{P}_{2}$, and is dated by nannofossils from about 2.4 $\mathrm{Ma}$ (not less than $2.35 \mathrm{Ma}$ ) to 2.9 (minimum) or $3.3 \mathrm{Ma}$ (maximum). A short interval barren of coccoliths and planktonic foraminifers marks this level in Section 60419-3 (Lang and Wise; Moullade; both this volume). Although Moullade notes no break in sedimentation here, a hiatus at this level can easily be fitted against his range chart (Moullade, this volume, "Distribution of . . . foraminifers, ... Site 604, Fig. 4), particularly if his postulated Zone PL4 is disregarded.

Backman (1979) dated a similar hiatus at DSDP Site 111A (Orphan Knoll), which he attributed to increased bottom-current velocities that resulted from increased bottom-water formation in response to the closure of the Central American Seaway. He also suggested that this closure could have triggered the onset of the Labrador Current. Lang and Wise (this volume) suggest that such a reorganization of current regimes could have caused the hiatus at Site 604 as well. This hiatus could also represent the onset of Northern Hemisphere continental glaciation, which Backman (1979) and Shackleton et al. (1984) date at about 2.4 to $2.5 \mathrm{Ma}$. Most investigators link this event closely with the closure of the Central American Seaway. Either event might have triggered current erosion along the upper rise. If the erosion at Site 604 began as late as 2.4 to $2.5 \mathrm{Ma}$, it would require the removal of at least $25 \mathrm{~m}$ of sediment to produce the observed hiatus (assuming deposition at the pre-glacial rate of $34 \mathrm{~m} / \mathrm{m} . \mathrm{y}$.$) .$

In any event, Horizon $\mathrm{P}_{2}$ on the upper rise appears to correspond to Reflector Blue of Mountain and Tucholke (1985), which they map throughout the continental rise of this region and to the south along the Blake Outer Ridge and Basin. They attribute Reflector Blue to a major pulse of intensified bottom currents linked to the onset of North American glaciation.

Another hiatus in the Pleistocene, between Cores 60411 and -10 , corresponds to local seismic reflection Horizon $\mathrm{P}_{1}$. There is considerable reworking of older foraminifers in Cores 10 and 11 (Moullade, this volume, "Distribution of . . f foraminifers, . . . Site 604"), which also show evidence of disturbance (see core photographs, Site 604/605 chapter, this volume), perhaps from slumping associated with the erosion. The hiatus spans a maximum of about 0.65 m.y. (Lang and Wise, this volume). It appears to denote an intensification of Northern Hemisphere glaciation, and would correspond to the sea-level low stand recorded at the base of the third-order cycle TB3.9 by Haq et al. (in press). By the calculations of Lang and Wise (this volume), the sedimentation rate for the late Pleistocene/Holocene would be an extremely high $201 \mathrm{~m} / \mathrm{m}$.y., the highest in the section.

Before leaving this discussion of the New Jersey transect, it should be pointed out that evidence for continued instability and downslope transport of sediments is quite apparent in this area. In particular, we wish to call attention to the highly contorted and convolute patterns in the Pleistocene sediments of Subunit IB at Site 604. These are interpreted as internal slump structures, features which indicate unstable slope conditions. Slumping within Quaternary deposits has been widely observed on the continental slope in the detailed seismic surveys by Robb, Hampson, Kirby, et al. (1981) and Robb, Hampson, and Twichell (1981), and these downslope, gravitydriven processes are thought to have continued in this area from the Holocene to the present (Stanley et al., 1984).

Having described Neogene sedimentation on the slope and upper rise off New Jersey, we now return to examine coeval sedimentation on the lower rise at Site 603. A physiographic sketch relating the Leg 93 drill sites and others in the two study areas is given in Figure 35 (after Ewing and Hollister, 1972).

\section{NEOGENE CLASTIC SEDIMENTATION AT SITE 603 AND THE EVOLUTION OF THE HATTERAS OUTER RIDGE}

Earlier we ended our discussion of Paleogene sedimentation at Site 603 with the observation that strong erosion on a regional scale along the Horizon $\mathrm{A}^{\mathrm{u}}$ disconformity had followed the deposition of the Eocene biosiliceous units. This erosion marked a radical departure from the pelagic depositional regime which had dominated sedimentation on both the slope and rise of our study area during the Eocene. For the first time, there is evidence of strong abyssal currents operating along the contour of the western boundary of the North American Oceanic Basin.

The first sediments deposited above the $\mathrm{A}^{\mathrm{u}}$ disconformity at Site 603 are the lower Miocene, light yellowish brown to brown hemipelagic clays of Subunit ID (Fig. 6). Sedimentation rates were sufficiently low to allow oxidation of these clays. Biogenic productivity was also low (or else accumulation was sufficiently slow to allow dissolution of all calcareous and siliceous fossils), because only fish teeth accumulated in these sediments. Abyssal currents had obviously waned, thereby allowing sediments to accumulate again; climate had also ameliorated somewhat.

Sedimentation rates and biosiliceous productivity began to increase by the close of the early Miocene, however, as the first of the massive series of reduced, dark greenish gray claystones began to accumulate at Site 603 . Those in Core 603B-13 (946 m sub-bottom) are reliably dated as late early Miocene in age (Calocycletta costata radiolarian Zone; Nishimura, this volume).

Downslope processes began to dominate sedimentation at Site 603 during the late middle Miocene (nannofossil Zone CN5; 14.4 to $10.8 \mathrm{Ma}$ according to Berggren 


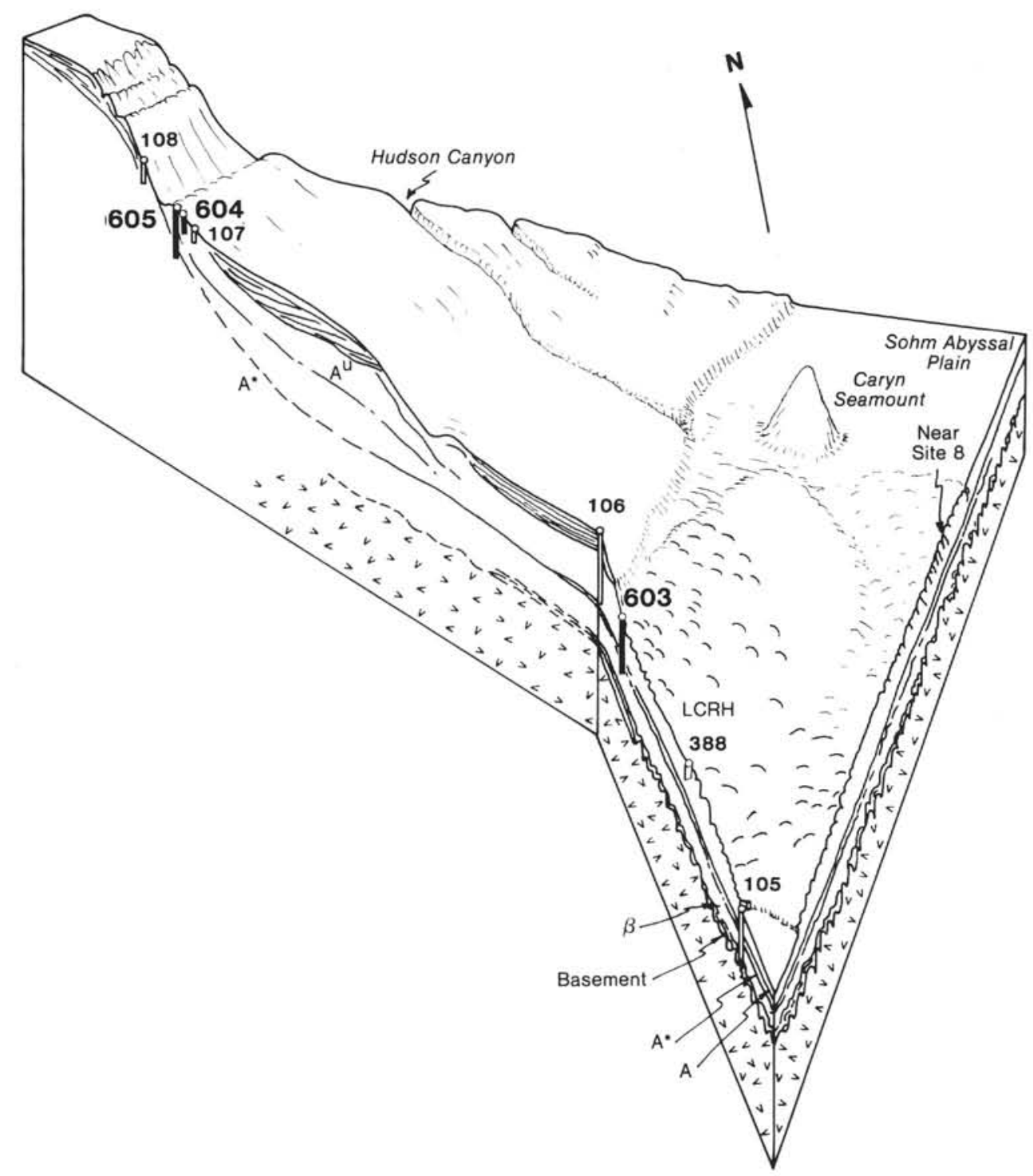

Figure 35. Sketch of the physiography of the slope and continental rise in the Leg 93 study area showing the relationship between Sites 604 and 605 on the upper rise and Site 603 on the lower rise. Other drill sites and principal seismic reflection horizons also shown (after Ewing and Hollister, 1972, fig. 11). $\mathrm{LCRH}=$ lower continental rise hills.

et al., 1985), just as they must have at about this time on the upper rise and slope. Sedimentation rates increased markedly with the deposition of dark hemipelagic clays and occasional sand or silt turbidites (Subunit IC, Fig. 6), which were fed by the outflow of terrigenous material (including wood debris, mica, etc.) from the shelf. Detailed descriptions and photographs of these turbidites are given in Haggerty et al. (this volume, Figs. 5 to 9).

During nannofossil Zone CN5b time (13.1 to 10.8 Ma), a sandy turbidity current that had apparently cut into Eocene strata of the outer shelf or slope was able to transport a large number of delicate Eocene coccoliths to the site without appreciable damage (wash core Sample 603B-6M,CC, 831.0-850.2 m). This event, not repeated again in the section, is quite important. It might have heralded the initiation of canyon cutting, at least on a limited scale, along the slope, and could have pre- ceded by as much as 3 m.y. the deposition of the Tortonian debris flows at Site 604 discussed previously.

Generally flat-lying to mounded at first, the sediments of Subunit IC began to be caught up and shaped into a large-scale $(50 \times 500 \mathrm{~km})$, elongate, drift deposit by the Western Boundary Undercurrent (WBUC) by the time Subunit IB was deposited. This signaled a change in Atlantic bottom-water, circulation and marked the birth of the feature now called the Hatteras Outer Ridge (HOR) (Fig. 36). As the material was built up above the level of the CCD (which had been falling at an increased rate during the middle Miocene; Jansa et al., 1979, fig. 23), appreciable numbers of calcareous microfossils began to accumulate, the first since the site passed beneath the CCD following the Barremian.

As suggested by Tucholke and Laine (1982), a relatively constant northeast-southwest bottom current and 
a west-east turbidite input from the margin led to the formation of "antidune-like" sediment waves which eventually grew to form the present lower continental rise hills (Figs. 5, 35, 36). These sediment waves are developed above reflection Horizon X, beginning just below Horizon $\mathrm{M}_{2}$ (Figs. 5, 6). A sharp erosional disconformity is indicated within the sediment wave sequence by Horizon $\mathrm{M}_{2}$, which truncates the underlying reflectors, as shown in the partial profile in Figure 6.

A sedimentation curve based on nannofossils with correlations to seismic stratigraphy has been proposed by Muza et al. (this volume) and is shown in Figure 37. Coccoliths within Subzone CN5b are generally sparse and poorly preserved; thus these authors cannot detect within this long interval a hiatus that would correspond to Horizon X. Horizon X has been traced along multichannel seismic line 77 (Fig. 5) by Tucholke and Laine (1983) and Mountain and Tucholke (1985), who interpret it as a time-transgressive seismic facies boundary (not as a time horizon).

\section{Age of Seismic Reflection Horizon $\mathbf{M}_{2} /$ Merlin at Site 603}

The next reflection horizon upcolumn from Horizon $\mathrm{X}$, local Horizon $\mathrm{M}_{2}$, is also the most prominent within the sediment drift at this site. We equate $\mathrm{M}_{2}$ with Horizon Merlin of Mountain and Tucholke (1985), who find it to be a level, continuous reflector that commonly truncates underlying reflectors. They consider it to be of widespread, regional importance, and note that the stratigraphic sequences at DSDP Sites 106 and 104 indicate an age for the reflector within planktonic foraminiferal Zone N14.

Muza et al. (this volume; see Fig. 6) date a disconformity which they correlate with Horizon $\mathrm{M}_{2} /$ Merlin, as being within the overlap between foraminiferal Zone N14 (Site 603 chapter, this volume) and coccolith Zone CN6. The top of Zone CN6 and Zone CN7a are missing; therefore the maximum age of the hiatus is $10.5-10.8 \mathrm{Ma}$ and the minimum is $10.0-8.8 \mathrm{Ma}$, using the time scale of Berggren et al. (1985). Thus the lowermost Tortonian and perhaps slightly older sediments have been eroded at this site. This paleontologic date for $\mathrm{M}_{2} /$ Merlin is in close agreement with that published by Mountain and Tucholke (1985). It coincides remarkably well with the date of $10.5 \mathrm{Ma}$ that $\mathrm{Haq}$ et al. (in press) independently assigned to the base of the profound eustatic sea-level drop associated with the base of their Supercycle/Cycle TB3.1. It should be further noted that the preprint by $\mathrm{Haq}$ et al. was not available to Muza et al. (this volume) when they dated the $\mathrm{M}_{2}$ /Merlin event at Site 603 .

As indicated in Figure 37, Muza et al. (this volume) date a second disconformity $30 \mathrm{~m}$ farther upsection, which they believe corresponds to an equally strong but unnamed reflector about $0.3 \mathrm{~s}$ above $\mathrm{M}_{2}$ (Fig. 6). This is dated at about 8.5 Ma. Sedimentation rates for the lower Tortonian sediments immediately above this unnamed reflector are the highest that could be measured in the section (192 m/m.y.).

Muza et al. (this volume) suggest that the relative thinness at Site 603 of the CN7/CN8a lower Tortonian sediments plus the hiatuses there indicate that a significant amount of these sediments either bypassed the site or were subsequently eroded during episodes of intensified current activity. Sedimentation rates might actually have been quite high through this interval were it not for these hiatuses. During nannofossil Zone CN8b time, however, the site apparently did lie within the locus of high net sediment accumulation, because the sedimentation rates reached their maximum, over twice that of the overlying upper Miocene-Pliocene-Pleistocene interval. These sedimentation rates on the lower rise indicate that canyon cutting along the slope should have been most intense during the early Tortonian, in close agreement with the observations of debris flows accorded that age at Site 604 by Lang and Wise (this volume).

Although Muza et al. (this volume) closely agree with Mountain and Tucholke (1985) on the paleontologic correlation for the disconformity associated with Horizon $\mathrm{M}_{2} /$ Merlin, their correlation with the absolute time scale is different because each set of authors used a different unpublished edition of the Berggren scale (see discussion by Muza et al., this volume). Mountain and Tucholke (1985) arrive at a date of $12 \mathrm{Ma}$ (late middle Miocene), which is older than the figure used in the present volume (about 10.5 to $9.6 \mathrm{Ma}$ ). For that reason, the explanations rendered for the erosive event are different. In this volume and in Wise et al. (1986), we relate it to Antarctic glaciation (specifically to the onset of West Antarctic Ice Sheet formation). Mountain and Tucholke

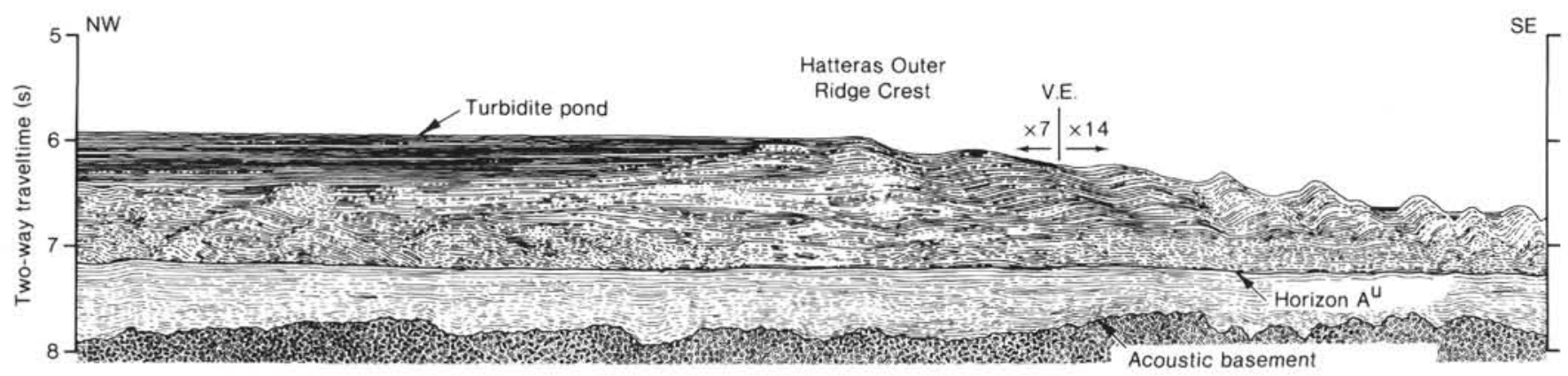

Figure 36. A tracing of a single-channel record from Conrad 2101-77 multichannel seismic line across the Hatteras Outer Ridge Crest which separates the turbidite pond to the northwest from the lower continental rise hills to the southeast (from Tucholke and Laine, 1982, fig. 4). 


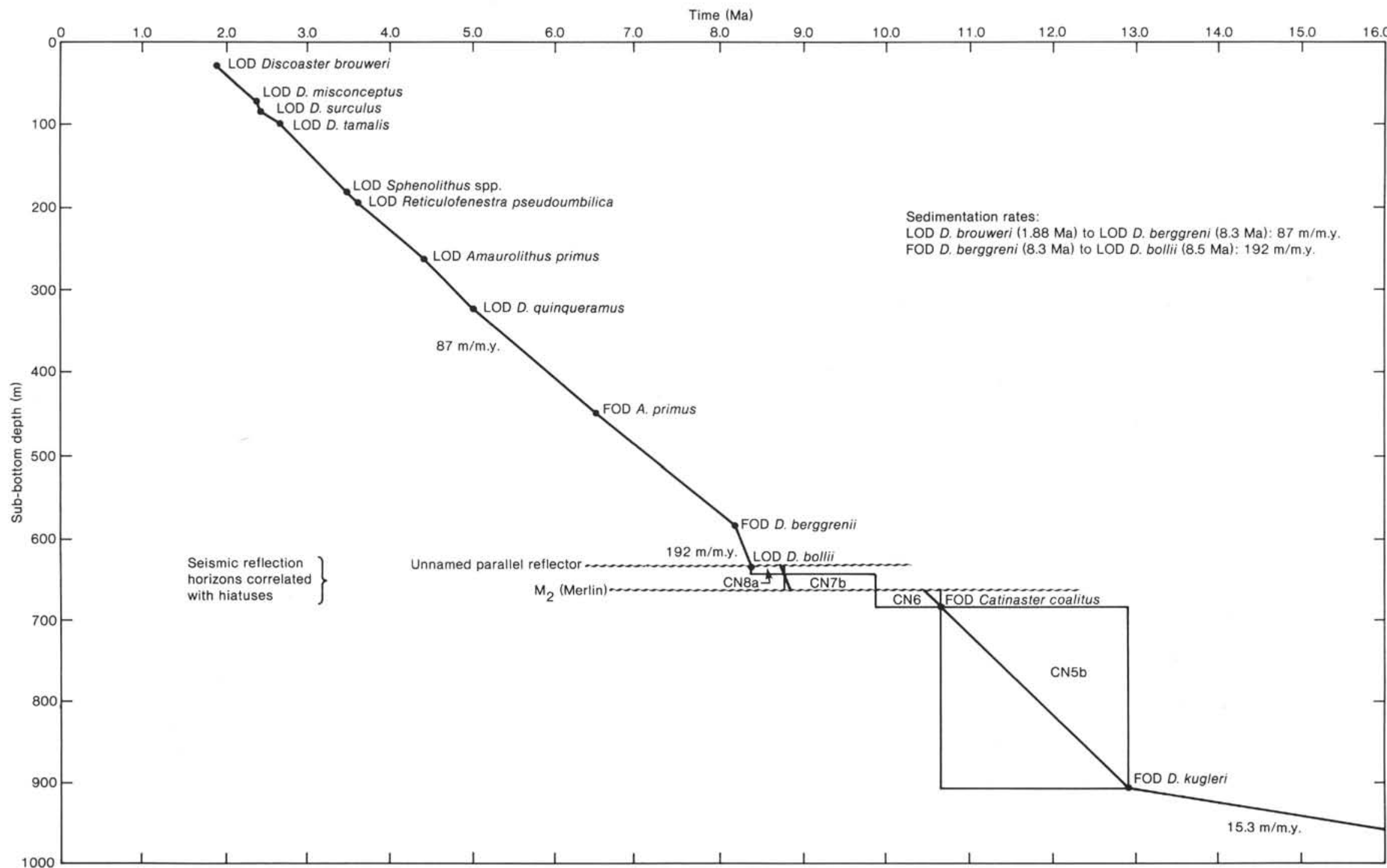

Figure 37. Sedimentation rates, hiatuses, and correlated reflectors for the Neogene sediment drift drilled at Site 603 (from Muza et al., Fig. 6, this volume). At this locality, local seismic reflection Horizon $\mathrm{M}_{2}$ is equated with Horizon Merlin of Mountain and Tucholke (1985), which is dated by Muza and Wise at about 10.5 to $9.6 \mathrm{Ma}$. 
(1985) suggest oceanographic or tectonic events peculiar to the North Atlantic, such as at the Greenland-Scotland Ridge.

\section{Late Tortonian to Early Pleistocene Development of the HOR}

As indicated on Figure 37, the sedimentation rate for the upper Tortonian through lower Pleistocene section is remarkably uniform (averaging $87 \mathrm{~m} / \mathrm{m} . \mathrm{y}$.). No other hiatuses were detected by either the nannofossil or foraminiferal studies (Muza et al.; Ma'alouleh and Moullade; both this volume). In particular, there is no hiatus which would correspond to regional seismic Reflector Blue, which was so well defined at Site 604 (as local Horizon $\mathrm{P}_{2}$ ), and which Mountain and Tucholke (1985) attribute to a second major pulse of intensified bottom water subsequent to the Merlin event. Ma'alouleh and Moullade (this volume) do see in the planktonic foraminiferal record of Site 603 significant cooling at about the time of Northern Hemisphere glaciation, but no discernible hiatus. Mountain and Tucholke (1985, fig. 8-30) trace Reflector Blue on Conrad seismic line 2101-77 beneath the turbidite pond to the west of Site 603, but apparently not beneath the crest of the Hatteras Outer Ridge adjacent to our drill site. It is not clear why a regional reflector such as Blue would be observed beneath the turbidite pond but not within the contourites of the HOR.

As the sediment waves were being constructed (Fig. 36 ), however, the crest of the HOR grew apace where the turbidity currents were intercepted by the Western Boundary Undercurrent (Tucholke and Laine, 1982). This formed a "natural levee" behind which coarse terrigenous turbidites have been ponded, particularly during glacial times (DSDP Site 106; Hollister, Ewing, et al., 1972). Remarkably, no coarse clastics bypassing the turbidite pond were deposited with the clays of the HOR at our locality, the crest of which, unlike today, was situated topographically above the sediment pond. As a result, no sandy contourites are present in our section and sediments of the HOR are monotonously uniform, consisting of a homogenous mixture of clay and silt (muddy contourites of Stow and Lovell, 1979). Our seismic analysis (Fig. 38) suggests that the two grew contemporaneously at least into the early Pleistocene (Helicosphaera sellii Zone of Gartner, 1977 ; 1.45 to $1.37 \mathrm{Ma}$ according to Backman and Shackleton, 1983), and, as indicated previously, our core data show no appreciable break in sedimentation at Site 603 until that time. The ridge, however, lost much of its prominence as it grew more slowly than the massive glacial turbidite accumulations. Today at Site 603, the ridge crest is actually slightly below the main terrace, of the turbidite pond and would not stand out if it were not for a shallow moat behind it. We expect that the main current runs in the valley located above the site, where it has prevented deposition since early Pleistocene time (there are no signs of erosion) and that a side eddy has created the moat behind the ridge (coiled arrow above moat, Fig. 38).

\section{SUMMARY AND CONCLUSIONS}

In their comprehensive review and synthesis of the geologic history of the U.S. Atlantic continental mar- gin, Mountain and Tucholke (1985) interpret sedimentation in terms of the interplay of three main processes: (1) pelagic sedimentation, (2) downslope (or cross-slope) detrital sedimentation and erosion, and (3) along-slope (or "contour") detrital sedimentation and erosion. As outlined in their figure 8-1 (cf. our Fig. 39) and reviewed briefly here, a hierarchy of controls exists over these processes. In shallow-marine environments, changes in sea level, river input, reefs, faulting, slumping, and local diapirism are among the dominant controls in sedimentation, whereas along the lower continental rise these factors are overshadowed by abyssal currents and vertical fluctuations in the calcite compensation depth (CCD). Thus the balance among these various controls shifts when traversing from shallow-marine to deep-marine environments. Along the continental slope and rise, this balance has also shifted through time during the evolution of the North American Basin. Specifically, those controlling factors which produced turbidity currents and regulated pelagic sedimentation were most influential on Mesozoic and Paleogene sedimentation patterns, whereas after the Eocene, those factors which generated contour-following bottom currents have played an equally important, if not dominant, role.

In concluding this summary of Mesozoic-Cenozoic depositional environments revealed by DSDP Leg 93 drilling off the Atlantic margin, we present a modification (made by JEVH) of Mountain and Tucholke's (1985) figure 8-1. As seen in our Figure 39, the relationship between eustatic sea level and detrital influx and ocean circulation has been emphasized. This is a reflection of our belief that effects of processes which produced the coastal onlap curve of Vail and his colleagues can be detected in the deep sea, particularly during the Cenozoic, as suggested by Vail et al. (1980) and more recently by Poag and others (see summary by Kerr, 1984).

In stating this opinion, we do not wish to ignore contrary opinions and other modes of seismic analysis and modeling which have been applied to our study area (Watts, 1982; Thorne and Watts, 1984; Watts and Thorne, 1984; see also discussion by Miller et al., 1985, which seeks to reconcile some of the divergent viewpoints). Watts and Thorne (1984) used data from the COST B-2 and B-3 wells of the Baltimore Canyon Trough to conduct stratigraphic modeling of the western Atlantic margin, and their results led them to question the utility of the sequence analysis techniques of Vail and his colleagues (1977, 1980, 1984). As explained by Olsson and Wise (this volume), the record analyzed by Watts and Thorne (1984) is incomplete, in part because of the intervention of the ECSU, which removed major portions of the Maestrichtian and Paleocene record along the middle to outer shelf. Thus, it is only through the integration and correlation of the coastal plain section with the upper rise section at Site 605 that the Vail sequences and their boundaries can be recognized and correlated across the Baltimore Canyon Trough and similar shelf-slope settings (Olsson and Wise, this volume).

Our seismic data have been presented in Figures 5, 6, 21 , and 22 of this paper, and the dating of prominent reflection horizons has been noted throughout this narrative. More detailed analyses are given in the site chap- 

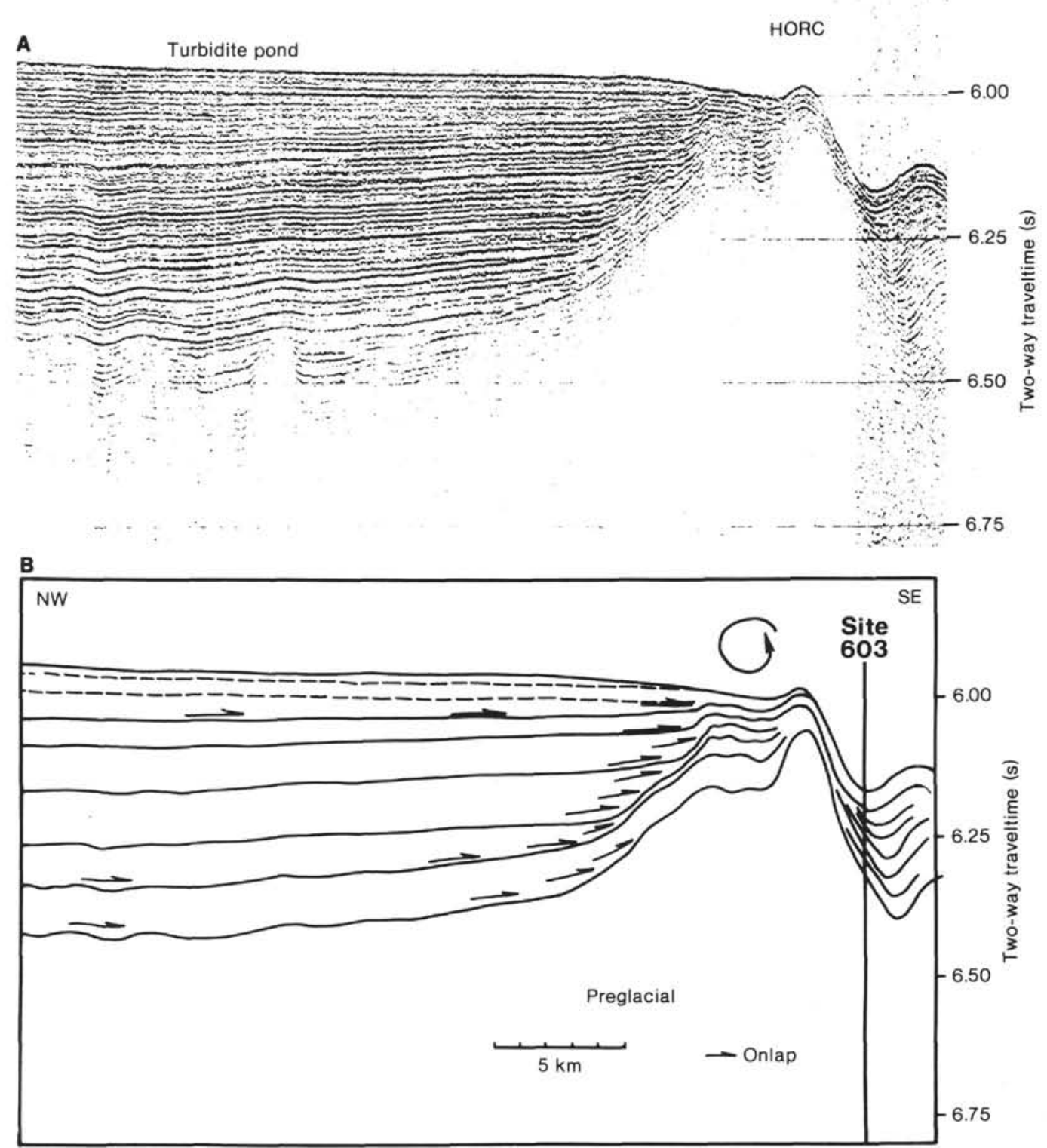

Figure 38. Original profile (A) and interpreted line drawing (B) of single-channel Glomar Challenger Cruise 93 seismic reflection profile across DSDP Site 603, the crest of the Hatteras Outer Ridge (HORC), and the turbidite pond to the west.

ters. As noted in previous publications by the Leg 93 shipboard party (cited in the introduction to this chapter) and with the few minor exceptions noted here, our results are in strong agreement with those predicted by Vail et al. (1977), as recalibrated by Haq et al. (in press). In particular, we recognize in the offshore area many of the prominent Type I sequence boundaries of the Vail et al. scheme. It should also be noted that the recalibration by Haq et al. has been partially based on a re-examination of data from the New Jersey margin (P. R. Vail, personal communication, 1986).

Our paleontologic dating of the major reflection surfaces described by Mountain and Tucholke (1985) agrees well for their Reflector Merlin on the lower rise and for their Reflector Blue on the upper rise (Fig. 34). Rather different correlations are given for both reflectors on the upper rise by Poag (1985a). As Poag emphasizes (1985a, p. 362), these differences "accentuate the difficulty in- herent in tracing seismic reflectors long distances from relatively thin, uncomplicated, lower-rise and abyssal plain sequences to the much thicker and more complex fabric of the upper-rise wedge . . . all seismostratigraphic interpretations of this upper-rise section must be considered tenuous, because the seismic sequences seaward of Site 604 remain unsampled; their ages and those of the bounding unconformities are still unknown." Tracing these reflectors across the slope break (where Neogene sediments have been completely removed in our study area) is even more difficult and tenuous, as seen in the case of matching the $\mathrm{A}^{*}$ (or $\mathrm{A}^{*}$ ?) reflector here with that on the lower rise.

We have added in Figure 39 feedback loops which emphasize the relationships between changes in climate, eustatic sea level, and ocean circulation. The diagram further stresses the crucial role of the biosphere in sedimentation processes. Note, for instance, that eustasy in- 


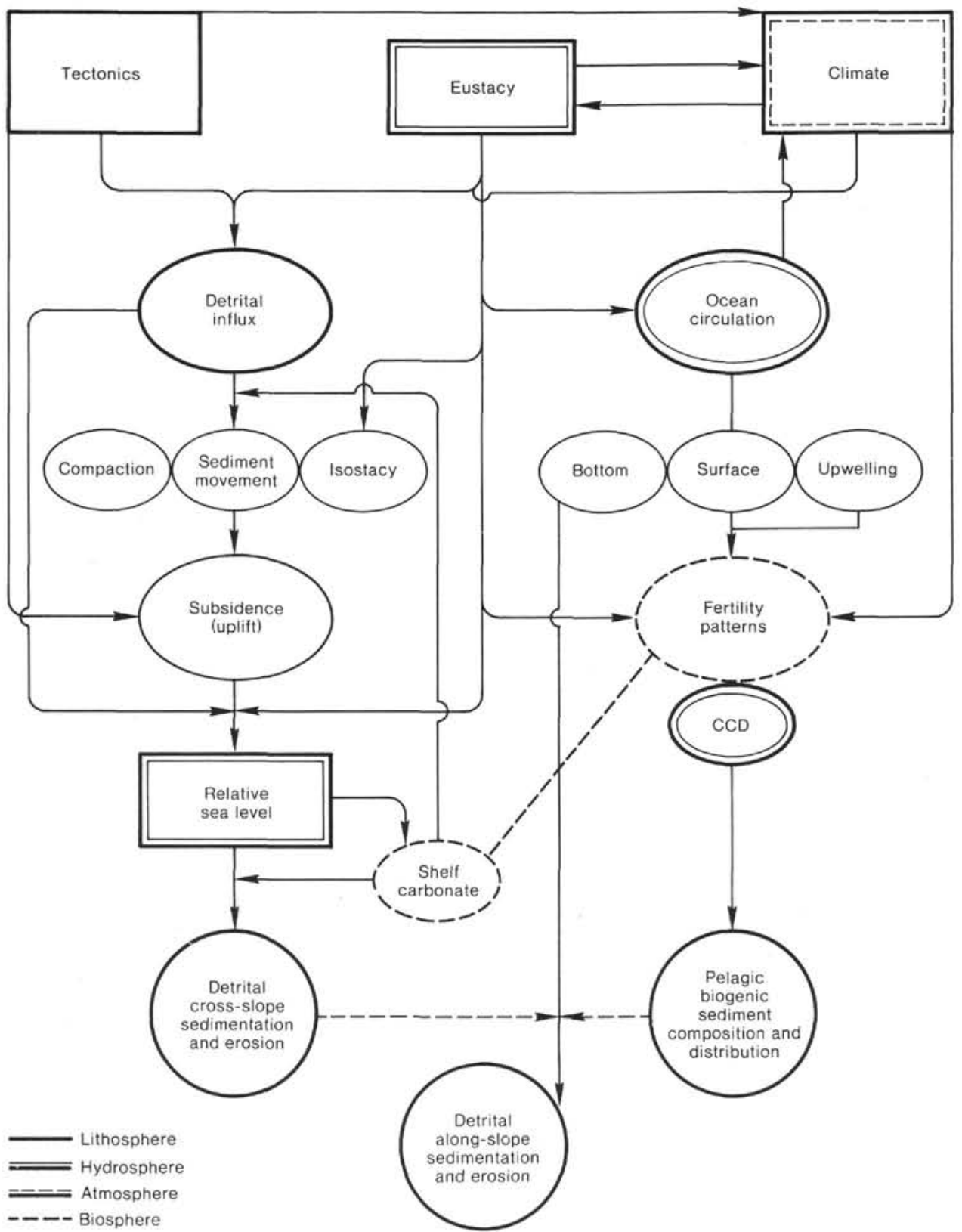

Figure 39. Summary of the hierarchy and interaction of the principal controls on sedimentation and erosion along the U.S. Atlantic slope and rise (modified from Mountain and Tucholke, 1985). Rectangles $=$ underlying causes (agents), ellipses $=$ intermediate processes, circles $=$ end products.

fluences the oceanic fertility pattern not only indirectly by its influence on ocean circulation, but also directly. In particular, during times of generally low or falling sea level, the ocean receives an increasing amount of nutrients, and a growing rain of planktonic skeletons adds to the deep-sea sediment, thereby depressing the CCD (as during the Neocomian; hence the extensive Blake-Bahama Formation carbonates). The reverse process takes place in the deep sea during times of generally high or rising sea level, when nutrients, carbonates, and clastic sediments are all largely trapped on the widening shelves (see Hay, 1981, for a detailed discussion). This effect is particularly noticeable during extreme high stands and periods of rapid sea-level rise and can be seen at Site 603 in the starved "red clays" of Unit III and in the Aptian/ Albian (Unit IV) and early/middle Miocene (Subunit ID), respectively.

The highlights of DSDP Leg 93 drilling are many and have been noted throughout this paper. Those that come most readily to mind are:

1. The discovery of the Neocomian Cape Hatteras Deep-Sea Fan Complex, with its important implications for sea-level changes, the timing and extent of shelfedge carbonate reefal bank development, the petroleum potential of the adjacent slope/upper rise, and the climatic and tectonic changes and perturbations reviewed previously. 
2. The correlation and age calibration of widely used oceanic reflection horizons and continental margin seismic sequence boundaries. These results were in close agreement with the predicted and subsequently recalibrated coastal onlap/offlap and eustatic sea-level curves of Vail and his colleagues.

3. The discovery of spectacular evidence of a major canyon-cutting episode along the margin during the Tortonian-Messinian(?), perhaps the most important event of this nature during the Miocene.

4. The discovery on the lower rise of a most unusual set of cross-bedded spherules, originally of glassy composition, that are thought to represent the deposition of $\mathrm{K} / \mathrm{T}$ boundary clay material by a turbidite current.

\section{ACKNOWLEDGMENTS}

The two-volume set of core descriptions and scientific manuscripts concluded by the present paper is a testament to the enthusiasm, dedication, patience, and fortitude of the scientists and crew who took part in this cruise. We have been greatly aided by shore-based colleagues who have enhanced our efforts to analyze the record amount of core material recovered and to put forward the scientific findings. It has been our privilege to summarize these results on behalf of the 86 authors and co-authors who participated in the effort to bring this volume to press.

This paper is an outgrowth of our unpublished "Preliminary Report," which was written aboard ship and widely circulated shortly after the cruise. It was updated at our postcruise meeting of May, 1984, and subsequently by the papers submitted to this volume. Parts of the original "Preliminary Report" as modified at various stages in its evolution have appeared elsewhere (see references in the "Introduction") and are repeated here with only slight modifications in wording in order to maintain scientific consistency among our various reports. We especially thank The Geological Society of London and Blackwell Scientific Publications, Ltd., for permission to reproduce figures and text that appeared in the article by Wise et al. (1986). These include Figures $1,5 \mathrm{~B}, 6-9,11,17,21 \mathrm{~B}, 22,23,32,33,35,38$, and 39 from the present paper. Van Nostrand Reinhold Co. provided permission to modify and use Figures 14 and 15.

We are grateful to the Deep Sea Drilling Project for the opportunity to participate on Leg 93, to Captain Sidney Shuman and the support staffs of the Glomar Challenger for their untiring efforts on our behalf, and to the DSDP Production and Editorial Staff, which did its utmost to make our tasks of coordinating and summarizing this volume as painless as possible. Special credit is due Mrs. Jan H. Blakeslee, DSDP Publications Manager, who cheerfully assumed the editorship of this volume as staff was being reduced in anticipation of termination of the International Phase of Ocean Drilling.

Discussions with our many shipboard and shore laboratory colleagues have been most stimulating and helpful, and we thank them for the reproduction of many figures used to illustrate this synthesis. We particularly wish to acknowledge the expertise, helpful advice, and continuing discussions rendered generously by researchers who did not participate in Leg 93. These include B. Charlotte Schreiber, Daniel Habib, Gregory S. Mountain, John Farre, and Kenneth G. Miller (all affiliated with Lamont-Doherty Geological Observatory), Brian E. Tucholke, William A. Berggren (Woods Hole Oceanographic Institution), John S. Schlee (U.S.G.S., WHOI), Richard K. Olsson (Rutgers University, New Brunswick), John H. Puffer (Rutgers University, Newark), Felix M. Gradstein, Mark A. Williamson, and Lubomir F. Jansa (Bedford Institute of Oceanography, Dartmouth, Canada), P. C. de Graciansky (Paris), and Roger Amato, Gary M. Edson, and their colleagues at the Minerals Management Service, Vienna, Virginia.

Equally important have been similar contributions of time, talent, and helpful discussion from colleagues in industry, particularly Peter R. Vail, Bilal U. Haq (both of Exxon Production Research Co., Houston), Edward R. Ringer, H. L. Patten, and Edward Picou (Shell Offshore Inc., New Orleans), and Dennis R. Prezbindowski and Edward D. Pittman (Amoco Research Center, Tulsa). Mountain, Tucholke,
Berggren, Puffer, Olsson, Williamson, Vail, and Haq provided valuable and timely preprints which measurably facilitated our understanding of the research problems at hand. Mountain, Tucholke, and Charles D. Hollister (WHOI) provided figures from their published or unpublished work.

Reviews of precursor drafts of this paper by Colin Summerhayes (British Petroleum Research Center, England), Brian Funnell (Norwich University, England), and our DSDP Staff Representative, Dean A. Dunn (University of Southern Mississippi) measurably improved the manuscript. A later draft was refereed for DSDP by John Schlee and Kim D. Klitgord, who rendered most helpful and detailed critical reviews. Rosemary Raymond, Jim Breza (FSU), and the highly skilled and efficient DSDP Production Staff assisted generously in the preparation of this manuscript.

\section{REFERENCES}

Alvarez, L. W., Alvarez, W., Asaro, F., and Michel, H. V., 1980. Extraterrestrial cause for the Cretaceous-Tertiary extinction. Science, 208:1095-1108.

Amato, R. V., and Giordano, A. C., 1985. Great Stone Dome-great disappointment? Am. Assoc. Pet. Geol. Bull., 69:1433.

Anderson, J. L., 1948. Cretaceous and Tertiary Subsurface Geology. Maryland Dept. Geol. Mines Water Res. Bull., 2.

Arthur, M. A., 1979. Origin of Upper Cretaceous multicolored claystones of the western Atlantic. In Tucholke, B. E., Vogt, P. R., et al., Init. Repts. DSDP, 43: Washington (U.S. Govt. Printing Office), $417-420$.

Arthur, M. A., Dean, W. E., and Schlanger, S. O., 1985. Variations in the global carbon cycle during the Cretaceous related to climate, volcanism, and changes in atmospheric $\mathrm{CO}_{2}$. In Sundquist, E. T., and Broecker, W. S. (Eds. ), The Carbon Cycle and Atmospheric $\mathrm{CO}_{2}$ : Natural Variations Archean to Present: Washington (Am. Geophys. Union Monogr.), 32:504-529.

Arthur, M. A., Schlanger, S. O., and Jenkyns, H. C., 1986. The Cenomanian-Turonian oceanic anoxic event, II. Paleoceanographic controls on organic matter production and preservation. In Brooks, J., and Fleet, A. (Eds.), Marine Petroleum Source Rocks: (Geol. Soc. London).

Backman, J., 1979. Pliocene biostratigraphy of DSDP Sites 111 and 116 from the North Atlantic Ocean and the age of Northern Hemisphere glaciation. Acta Univ. Stockh., Stockh. Contr. Geol,, 32: 115-137.

Backman, J., and Shackleton, N. J., 1983. Quantitative biochronology of Pliocene and early Pleistocene calcareous nannofossils from the Atlantic, Indian, and Pacific oceans. Mar. Micropaleontol. 8: 141-170.

Berggren, W. A., Kent, D. V., Flynn, J. J., and Van Couvering, J. A., 1985. Cenozoic geochronology. Geol. Soc. Am. Bull., 96:14071418.

Cande, S. C., Larson, R. L., and LaBrecque, J. L., 1978. Magnetic lineations in the Pacific Jurassic quiet zone. Earth Planet. Sci. Lett., $41: 434-440$.

Chamley, H., Debrabant, P., Candillier, A.-M., and Foulon, J., 1983. Clay mineralogical and inorganic geochemical stratigraphy of BlakeBahama Basin since the Callovian, Site 534, Deep Sea Drilling Project Leg 76. In Sheridan, R. E., Gradstein, F. M., et al., Init. Repts. $D S D P, 76$ : Washington (U.S. Govt. Printing Office), 437-451.

Ciesielski, P. F., and Weaver, F. M., 1983. Neogene and Quaternary paleoenvironmental history of Deep Sea Drilling Project Leg 71 sediments, southwest Atlantic Ocean. In Ludwig, W. J., Krasheninnikov, V. A., et al., Init. Repts. DSDP, 71, Pt. 1: Washington (U.S. Govt. Printing Office), 461-477.

Coleman, J. M., Bouma, A. H., Roberts, H. H., Thayer, P. A., and DSDP Leg 96 Scientific Party, 1985. In Bouma, A. H., Normark, W. R., and Barnes, N. E. (Eds.), Submarine Fans and Related Turbidite Systems: New York (Springer-Verlag), pp. 312-318.

Duddy, I. R., and Miller, D. S., 1986. Shallow oil in northern Appalachian Basin: evidence for Early Cretaceous uplift from fission track analysis. Am. Assoc. Pet. Geol. Bull., 70:584.

Edson, G. M., 1986. Morphology and evolution of Mesozoic carbonate paleoshelf edge, Eastern Baltimore Canyon Trough. Am. Assoc. Pet. Geol. Bull., 70:586. 
Emery, K. O., and Uchupi, E., 1972 Western North Atlantic Ocean: Topography, Rocks, Structure, Water, Life, and Sediments. Am. Assoc. Pet. Geol. Mem., 17. er-Verlag).

1984. The Geology of the Atlantic Ocean: New York (Spring-

Emery, K. O., Uchupi, E., Phillips, J. D., Bowin, C. O., Bunce, E. T. and Knott, S. T., 1970. Continental rise off eastern North America. Am. Assoc. Pet. Geol. Bull., 54:44-108.

Ewing, J. I., and Hollister, C. D., 1972. Regional aspects of deep sea drilling in the western North Atlantic. In Hollister, C. D., Ewing, J. I., et al., Init. Repts. DSDP, 11: Washington (U.S. Govt. Printing Office), 951-973.

Ewing, J. I., and Rabinowitz, P. D. (Eds.), 1984. Eastern North American Continental Margin and Adjacent Ocean Floor, $34^{\circ}$ to $41^{\circ} \mathrm{N}$ and $68^{\circ}$ to $78^{\circ} \mathrm{W}$. Ocean Margin Drilling Program, Regional Atlas Series: Woods Hole (Marine Science International), Atlas 4.

Foland, K. A., and Faul, H., 1977. Ages of the White Mountain intrusives-New Hampshire, Vermont, and Maine, U. S. A. Am. J. Sci., 277:888-904.

Fullagar, P. D., and Bottino, M. L., 1969. Tertiary felsite intrusions in the Valley and Ridge Province, Virginia. Geol. Soc. Am. Bull., 80: 1853-1858.

Gartner, S., 1977. Calcareous nannofossil biostratigraphy and revised zonation of the Pleistocene. Mar. Micropaleontol., 2: 1-25.

Gibson, T. G., and Towe, K. M., 1971. Eocene volcanism and the origin of Horizon A. Science, 172:153-154.

Gieskes, J. M., Elderfield, H., Lawrence, J. R., Johnson, J., Meyers, B., and Campbell, A., 1982. Geochemistry of interstitial waters and sediments, Leg 64, Gulf of California. In Curray, J. R., Moore, D. G., et al., Init. Repts. DSDP, 64, Pt. 2: Washington (U.S. Govt. Printing Office), 675-694.

Graciansky, P. C. de, Deroo, G., Herbin, J.-P., Montadert, L., Müller, C., Schaaf, A., and Siegal, J., 1984. Ocean-wide stagnation episode in the Late Cretaceous. Nature, 308:346-349.

Gradstein, F. M., Grant, A. C., and Jansa, L. F., 1977. Grand Banks and J-Anomaly Ridge: a geological comparison. Science, 197:10741076.

Gray, K. J., and Gottfried, D., 1986. A geochemical study of three contrasting magma types of central Virginia emplaced at 195, 149, and 47 Ma: tectonic implications. Geol. Soc. Am. Abstr. Progr. 1986, p. 224.

Grow, J. A., 1980. Deep structure and evolution of the Baltimore Canyon Trough in the vicinity of the COST B-3 well. In Scholle, P. A. (Ed.), Geological Studies of the COST No. B-3 Well, United States Mid-Atlantic Continental Slope Area. U.S. Geol. Surv. Circ., 833: 117-125.

Hallam, A., 1984. Continental humid and arid zones during the Jurassic and Cretaceous. Palaeogeogr., Palaeoclimatol., Palaeoecol., 47:195-223.

Haq, B. U., Hardenbol, J., and Vail, P. R., in press. Chronology of fluctuating sea levels since the Triassic ( 250 million years ago to Present). Science.

Harland, W. B., Cox., A. V., Llewellyn, P. B., Pickton, C. A. G. Smith, A. G., and Walters, R., 1982. A Geologic Time Scale: Cambridge (Cambridge University Press).

Hay, W. W., 1981. Sedimentological and geochemical trends resulting from the breakup of Pangaea. Oceanol. Acta, No. Sp., Proc. 26 Int. Geol. Cong., Geology of Oceans Symposium, Paris, July 717,1980 , pp. $135-147$.

Hay, W. W., Barron, E. J., Sloan, J. L., and Southam, J. R., 1981. Continental drift and global pattern of sedimentation. Geol. Rundschau, 70:302-315.

Hedberg, H. D., 1970. Continental margin from viewpoint of the petroleum geologist. Am. Assoc. Pet. Geol. Bull., 54:3-43.

Hinte, J. E. van, 1976. A Jurassic time scale. Am. Assoc. Pet. Geol. Bull., 60:489-497.

Hinte, J. E. van, Wise, S. W., Biart, B. N. M., Covington, J. M., Dunn, D. A., et al., 1985a. DSDP Site 603: first deep penetration $(>1000 \mathrm{~m})$ of the continental rise along the passive margin of eastern North America. Geology, 13:392-396.

$1985 \mathrm{~b}$. Deep sea drilling on the upper continental rise off New Jersey: DSDP Sites 604 and 605. Geology, 13:397-400.

Hollister, C. D., Ewing, J. I., et al., 1972. Init. Repts. DSDP, 11: Washington (U.S. Govt. Printing Office).
Hurtubise, D. O., and Puffer, J. H., 1985. Nepheline normative alkalic dolerite of the Georges Bank Basin, North Atlantic: part of Early Cretaceous eastern North American alkalic province. Geol. Soc. Am. Prog. Abstr., 17:25.

Hurtubise, D. O., Puffer, J. H., and Cousminer, H. C., in press. An integrated investigation of an offshore subsurface igneous sequence, Georges Bank Basin, North Atlantic: evidence of recurrent deepseated strike-slip faulting related to major Mesozoic tectonic events. Geol. Soc. Am. Bull.

Hutchinson, D. R., Grow, J., Klitgord, K., and Swift, B. A., 1983. Deep structure and evolution of the Carolina Trough. In Watkins, J. S., and Drake, C. L. (Eds.), Studies in Continental Margin Geology. Am. Assoc. Pet. Geol. Mem., 34:129-152.

Jansa, L. F., 1981. Mesozoic carbonate platforms and banks of the eastern North American margin. Mar. Geol., 44:97-117.

Jansa, L. F., Enos, P., Tucholke, B., Gradstein, G., and Sheridan, R. E., 1979. Mesozoic-Cenozoic sedimentary formations of the North American Basin; western North Atlantic. In Talwani, M., Hay, W., and Ryan, W. B. F. (Eds.), Deep Drilling Results in the Atlantic Ocean: Continental Margins and Paleoenvironment. Am. Geophys. Union, Maurice Ewing Ser., 3:1-57.

Jansa, L. F., and MacQueen, R. W., 1978. Stratigraphy and hydrocarbon potential of the central North American Basin. Geosci. Cana$d a, 5: 173-183$.

Jansa, L. F., and Pé-Piper, G., 1985. Early Cretaceous volcanism on the northeastern American margin and implications for plate tectonics. Geol. Soc. Am. Bull., 96:83-91.

Jansa, L. F., and Wade, J. A., 1975. Geology of the continental margin off Nova Scotia and Newfoundland. In van der Linden, W. J. M., and Wade, J. A. (Eds.), Offshore Geology of Eastern Canada. Can. Geol. Surv. Pap. 74-30, Pt. 2, pp. 51-105.

Karlo, J. F., 1986. Results of exploration in Mesozoic shelf-edge carbonates, Baltimore Canyon Basin. Am. Assoc. Pet. Geol. Bull., 70:605-606.

Karpoff, A. M., Bourbon, M., Ancel, B., and Graciansky, P. C. de, 1985. Diagenetic polymetallic crusts at Sites 550 and 548 of Leg 80, northeastern Atlantic Ocean. In Graciansky, P. C. de, Poag, C. W., et al., Init. Repts. DSDP, 80, Pt. 2: Washington (U.S. Govt. Printing Office), 823-844.

Kent, D., and Gradstein, F. M., 1985. A Cretaceous and Jurassic geochronology. Geol. Soc. Am. Bull., 96:1419-1427.

Kerr, A. R., 1984. Vail's sea-level curves aren't going away. Science, 226:677-678.

Klitgord, K. D., and Grow, J. A., 1980. Jurassic seismic stratigraphy and basement structure of the western Atlantic magnetic quiet zone. Am. Assoc. Pet. Geol. Bull., 64:1658-1680.

Lancelot, Y., Hathaway, J. C., and Hollister, C. D., 1972. Lithology of sediments from the western North Atlantic, Leg XI, Deep Sea Drilling Project. In Hollister, C. D., Ewing, J. I., et al., Init. Repts. DSDP, 11: Washington (U.S. Govt. Printing Office), 901-950.

Lancelot, Y., Winterer, E. L., et al., 1980. Init. Repts. DSDP, 50: Washington (U.S. Govt. Printing Office).

Leg 93 Scientific Party/Leg 94 Scientific Party, 1984. Deep Sea Drilling Project drills margin and studies paleoclimate. Geotimes, 29(no. 4):16-18.

Leg 95 Scientific Party, 1984. Deep Sea Drilling Project adds data on the Atlantic margin. Geotimes, 29(no. 5):14-16.

Leg 96 Scientific Party, 1984. Challenger drills Mississippi Fan. Geotimes, 29(no. 7):15-18.

Leg 103 Scientific Party, 1986. ODP Leg 103 drills into rift structures. Geotimes, 31(no. 1):15-17.

Leg 93 Staff, 1983. The continental rise off North America. Nature, 305:386.

Libby-French, J. 1984. Stratigraphic framework and petroleum potential of northeastern Baltimore Canyon Trough, mid-Atlantic outer continental shelf. Am. Assoc. Pet. Geol. Bull., 68:50-73.

McGregor, B., Stubblefield, W., Ryan, W., and Twichell, D. C., 1982. Wilmington Submarine Canyon: a marine fluvial-like system. Geology, 10:27-30.

McHone, J. G., 1978. Distribution, orientations and ages of mafic dikes in central New England. Geol. Soc. Am. Bull., 89:1645-1655.

Mattick, R. E., Girard, O. J., Jr., Scholle, P., and Grow, J. A., 1978. Petroleum potential of United States Atlantic slope, rise and abyssal plain, Am. Assoc. Pet. Geol. Bull., 62:592-608. 
Miller, K. G., Mountain, G., and Tucholke, B. E., 1985. Oligocene glacio-eustasy and erosion on the margins of the North Atlantic. Geology, 13:10-13.

Mountain, G. S., and Tucholke, B. E., 1985. Mesozoic and Cenozoic stratigraphy of the United States Atlantic continental slope and rise. In Poag, C. W. (Ed.), Geologic Evolution of the United States Atlantic Margin: New York (Van Nostrand-Reinhold), pp. 293341 .

Murdmaa, I. O., Gordeev, V. V., Bazilevskaya, E. S., and Emelyanov, E. M., 1978. Inorganic geochemistry of the Leg 44 sediments. In Benson, W. E., Sheridan, R. E., et al., Init. Repts. DSDP, 44: Washington (U.S. Govt. Printing Office), 575-582.

Okada, H., and Bukry, D., 1980. Supplementary modification and introduction of code numbers to the "low-latitude coccolith biostratigraphic zonation" (Bukry, 1973; 1975). Mar. Micropaleontol., 5: 321-325.

Olsson, R. K. 1980. The New Jersey coastal plain and its relationship with the Baltimore Canyon Trough. In Manspeizer, E. (Ed.), Field Studies New Jersey Geol. and Guide to Field Trips of 52nd Annual Meeting New York State Geol. Assoc: Newark, New Jersey (Rutgers University), pp. 116-129.

Owens, J. P., and Gohn, G. S., 1985. Depositional history of the Cretaceous Series in the U.S. Atlantic Coastal Plain: stratigraphy, paleoenvironments, and tectonic controls of sedimentation. In Poag, C. W. (Ed.), Geologic Evolution of the United States Atlantic Margin: New York (Van Nostrand Reinhold), pp. 25-86.

Parkinson, N., and Summerhayes, C. P., 1985. Synchronous global sequence boundaries. Am. Assoc. Pet. Geol. Bull., 69:685-687.

Pittman, W. C., III, 1978. Relationship between eustacy and stratigraphic sequences of passive margins. Geol. Soc. Am. Bull., 89: 1389-1403.

Poag, C. W., 1982. Stratigraphic references section for Georges Bank Basin depositional model for New England passive margin. Am. Assoc. Pet. Geol. Bull., 66:1021-1041.

1985a. Cenozoic and Upper Cretaceous sedimentary facies and depositional systems of the New Jersey slope and rise. In Poag, C. W. (Ed.), Geologic Evolution of the United States Atlantic Margin: New York (Van Nostrand-Reinhold), pp. 343-365.

1985b. Depositional history and stratigraphic reference section for central Baltimore Canyon Trough. In Poag, C. W. (Ed.), Geologic Evolution of the United States Atlantic Margin: New York (Van Nostrand-Reinhold), pp. 217-264.

Poag, C. W., and Schlee, J. S., 1984. Depositional sequences and stratigraphic gaps on submerged United States Atlantic margin. In Schlee, J. S. (Ed.), Interregional Unconformities and Hydrocarbon Accumulation. Am. Assoc. Pet. Geol. Mem., 36:165-182.

Prior, D. B., Coleman, J. M., and Doyle, E. H., 1984. Antiquity of the continental slope along the middle-Atlantic margin of the United States. Science, 223:926-928.

Rad, U. von, and Arthur, M. A., 1979. Geodynamic, sedimentary and volcanic evolution of the Cape Bojador continental margin (NW Africa). In Talwani, M., Hay, W., and Ryan, W. B. F. (Eds.), Deep Drilling Results in the Atlantic Ocean: Continental Margins and Paleoenvironments. Am. Geophys. Union, Maurice Ewing Ser., 3: 187-203.

Rad, U. von, Hinte, J. E. van, Wise, S. W., Biart, B. N. M., Covington, J. M., Dunn, D. A., et al., 1984. Kretazisch-Kanozische Stratigraphie und Palaoenvironment-Entwicklungen Kontinentalfuss von dem ostlichen Nordamerika: erste Ergebnisse von DSDP Leg 93. Geol. Jahrb., 75:237-259.

Rawson, P. F., and Riley, L. A., 1982. Latest Jurassic-Early Cretaceous events and the "late Cimmerian unconformity" in North Sea area. Am. Assoc. Pet. Geol. Bull., 66:2628-2648.

Ringer, E. R., and Patten, H. L., 1986. Biostratigraphy and depositional environments of Late Jurassic and Early Cretaceous carbonate sediments in Baltimore Canyon Basin. Am. Assoc. Pet. Geol. Bull., 70:639-640.

Robb, J. M., 1984. Spring sapping on the lower continental slope, offshore New Jersey. Geology, 12:278-282.

Robb, J. M., Hampson, J. C., Kirby, J. R., and Twichell, D. C., 1981. Geology and Potential Hazards of the Continental Slope between Lindenkohl and South Toms Canyons Offshore Mid-Atlantic United States. Open File-Rept. U.S. Geol. Surv., 81-600.
Robb, J. M., Hampson, J. C., Jr., and Twichell, D. C., 1981. Geomorphology and sediment stability of a segment of the United States continental slope off New Jersey. Science, 211:935-937.

Robb, J. M., Kirby, J., Hampson, J. C., Jr., Gibson, P., and Hecker, B., 1983. Furrowed outcrops of Eocene chalk on the lower continental slope offshore New Jersey. Geology, 11:182-186.

Robertson, A. H. F., 1983. Latest Cretaceous and Eocene paleoenvironments in the Blake-Bahama Basin, Western North Atlantic. In Sheridan, R. E., Gradstein, F. M., et al., Init. Repts. DSDP, 76: Washington (U.S. Govt. Printing Office), 763-780.

Robertson, A. H. F., and Bernoulli, D., 1982. Stratigraphy, facies and significance of late Mesozoic and early Tertiary sedimentary rocks of Fuerteventura (Canary Islands) and Maio (Cape Verde Islands). In von Rad, U., Hinz, K., Sarnthein, M., and Seibold, E. (Eds.), Geology of the Northwest African Continental Margin: Berlin, Heidelberg, New York (Springer-Verlag), pp. 498-525.

Ryan, W. B. F., and Cita, M. B., 1977. Ignorance concerning episodes of ocean-wide stagnation. Mar. Geol., 23:197-215.

Schlanger, S. O., Arthur, M. A., Jenkyns, H. C., and Scholle, P. A., 1986. The Cenomanian-Turonian oceanic anoxic event, I. Stratigraphy and distribution of organic carbon-rich beds and the marine $\mathrm{S}^{13} \mathrm{C}$ excursion, In Brooks, J., and Fleet, A. (Eds.), Marine Petroleum Source Rocks: London (Geol. Soc. London).

Schlee, J. S., 1981. Seismic stratigraphy of Baltimore Canyon Trough. Am. Assoc. Pet. Geol. Bull., 65:26-53.

Schlee, J. S., Behrendt, J., Grow, J., Robb, J., and Mattick, R. E., 1976. Regional geologic framework off northeastern United States. Am. Assoc. Pet. Geol. Bull., 60:926-951.

Schlee, J. S., Dillon, W., and Grow, J. A., 1979. Structure of the continental slope off the eastern United States. Soc. Econ. Paleontol. Mineral. Spec. Publ., 27:95-117.

Schlee, J. S., and Grow, J. A., 1980. Seismic stratigraphy in the vicinity of the COST No. B-3 well. In Scholle, P. A. (Ed.), Geological Studies of the COST No. B-3 Well, United States Mid-Atlantic Continental Slope Area. U.S. Geol. Survey Circ., 833:111-116.

Schlee, J. S., and Jansa, L. F., 1981. The paleoenvironment and development of the eastern North American continental margin. Oceanol. Acta, 4(supp.):71-80.

Shackleton, N. J., Backman, J., Zimmerman, H., Kent, D. V., Hall, M. A., Roberts, D. G., et al., 1984. Oxygen isotope calibration of the onset of ice-rafting and history of glaciation in the North Atlantic region. Nature, 307:620-623.

Sheridan, R. E., Gradstein, F. M., et al., 1983. Init. Repts. DSDP, 76: Washington (U.S. Govt. Printing Office).

Sliter, W. V., 1977. Cretaceous foraminifers from the southwestern Atlantic Ocean, Leg 36, Deep Sea Drilling Project. In Barker, P. F., Dalziel, I. W. D., et al., Init. Repts. DSDP, 36: Washington (U.S. Govt. Printing Office), 519-574.

Smit, J., and Hertogen, J., 1980. An extraterrestrial event at the Cretaceous-Tertiary boundary. Nature, 285:198-200.

Smith, R. V., 1980. Provenance of mid-Atlantic continental margin sediments from the COST B-2 test well [Master's thesis]. University of Delaware, Newark.

Stanley, D. J., Nelsen, T., and Stuckenrath, R., 1984. Recent sedimentation on the New Jersey slope and rise. Science, 226:125-133.

Stow, D. A. V., and Lovell, J. P. B., 1979. Contourites: their recognition in modern and ancient sediments. Earth Sci. Rev., 14:251291.

Stubblefield, W. L., McGregor, B., Forde, E., Lambert, D., and Merrill, G. F., 1982. Reconnaissance in DSRV Alvin of a "fluvial-like" meander system in Wilmington Canyon and slump features in South Wilmington Canyon. Geology, 10:31-36.

Thayer, P. A., Harris, W. B., and Zullo, V. A., 1985. Eocene bentonite from the Castle Hayne Limestone, North Carolina coastal plain. Geol. Soc. Am., Abstr. Progr. 1985, p. 734.

Thorne, J., and Watts, A. B., 1984. Seismic reflectors and unconformities at passive continental margins. Nature, 311:365-368.

Tucholke, B. E., Ewing, J. I., and Schouten, H., 1982. Site Survey Report for Site ENA-3: Woods Hole, MA (Woods Hole Oceanogr. Inst.).

Tucholke, B. E., and Laine, E. P., 1982. Neogene and Quaternary development of the lower continental rise off the current United States east coast. In Watkins, J. S., and Drake, C. (Eds.), Studies 
in Continental Margin Geology. Am. Assoc. Pet. Geol. Mem., 34: 295-305.

Tucholke, B. E., and Mountain, G. S., 1979. Seismic stratigraphy, lithostratigraphy and paleosedimentation patterns in the North American basin. In Talwani, M., Hay, W., and Ryan, W. B. F. (Eds.), Deep Drilling Results in the Atlantic Ocean: Continental Margins and Paleoenvironment. Am. Geophys. Union, Maurice Ewing Ser., 3:58-86.

Tucholke, B. E., Vogt, P. R., et al., 1979a. Site 386: Fracture valley sedimentation on the central Bermuda Rise. In Tucholke, B. E., Vogt, P. R., et al., Init. Repts. DSDP, 43: Washington (U.S. Govt. Printing Office), 195-322.

1979b. Site 387: Cretaceous to Recent sedimentary evolution of the western Bermuda Rise. In Tucholke, B. E., Vogt, P. R., et al., Init. Repts. DSDP, 43: Washington (U.S. Govt. Printing Office), 323-391.

Uchupi, E., Sancetta, C., Eusden, J. J., Jr., Bolmer, S. J., Jr., McConnell, R., and Lambiase, J. J., 1984a. Lithofacies of top of J/J1 to Beta sequence. In Ewing, J. I., and Rabinowitz, P. D. (Eds.), Eastern North American Continental Margin and Adjacent Ocean Floor, $34^{\circ}$ to $44^{\circ} \mathrm{N}$ and $68^{\circ}$ to $78^{\circ} \mathrm{W}$. Ocean Margin Drilling Program, Regional Atlas Series: Woods Hole (Marine Science International), Atlas 4, e.

1984b. Lithofacies of lower part of Beta to $\mathrm{A}^{*}$ sequence. In Ewing, J. I., and Rabinowitz, P. D. (Eds.), Eastern North American Continental Margin and Adjacent Ocean Floor, $34^{\circ}$ to $41^{\circ} \mathrm{N}$ and $68^{\circ}$ to $78^{\circ} \mathrm{W}$. Ocean Margin Drilling Program, Regional Atlas Series: Woods Hole (Marine Science International), Atlas 4, $\mathrm{f}$.

Vail, P. R., Hardenbol, J., and Todd, R. G., 1984. Jurassic unconformities, chronostratigraphy, and sea-level changes from seismic stratigraphy and biostratigraphy. In Schlee, J. S. (Ed.), Interregional Unconformities and Hydrocarbon Accumulation. Am. Assoc. Pet. Geol. Mem., 36:129-144.

Vail, P. R., and Mitchum, R. M., Jr., 1979. Global cycles of relative changes of sea level from seismic stratigraphy. In Watkins, J. S.,
Montadert, L., and Dickerson, P. W. (Eds.), Geophysical and Geological Investigations of Continental Margins. Am. Assoc. Pet. Geol. Mem., 29:469-472.

Vail, P. R., Mitchum, R. M., Jr., Shipley, T., and Buffler, R. T., 1980. Unconformities of the North Atlantic. Phil. Trans. R. Soc. London, 294:137-155.

Vail, P. R., Mitchum, R. M., Jr., Todd, R. G., Widmeir, S., Thompson, S., III, Sangree, J. B., Bubb, J. B., and Hatlelid, W. G., 1977. Seismic stratigraphy and global changes of sea level. In Payton, C. E. (Ed.), Seismic Stratigraphy-Applications to Hydrocarbon Exploration. Am. Assoc. Pet. Geol. Mem., 26:49-212.

Watts, A. B., 1982. Tectonic subsidence, flexure and global changes of sea level. Nature, 297:469-474.

Watts, A. B., and Thorne, J., 1984. Tectonics, global changes in sea level and their relationship to stratigraphical sequences at the U.S. Atlantic continental margin. Mar. Pet. Geol., 1:319-339.

Williamson, M. A., in press. A quantitative foraminiferal biozonation of the Late Jurassic and Early Cretaceous of the East Newfoundland Basin. Micropaleontology.

Wise, S. W., Hinte, J. E. van, Mountain, G. S., Biart, B. N. M., Covington, J. M., Drugg, W. S., Dunn, D. A., Farre, J., Habib, D., Hart, M. B., Haggerty, J. A., Johns, M. W., Lang, T. H., Meyers, P. A., Miller, K. G., Moullade, M. R., Muza, J. P., Ogg, J. G., Okamura, M., Sarti, M., and Rad, U. von, 1986. Mesozoic-Cenozoic clastic depositional environments revealed by DSDP Leg 93 drilling on the continental rise off the Eastern United States. In Summerhayes, C. P., and Shackleton, N. J. (Eds.), North Atlantic Paleoceanography: Oxford (Blackwell Scientific Publications, Ltd.), Geol. Soc. Lond., Spec. Publ., 21:35-66.

Wise, S. W., and Weaver, F. M., 1974. Chertification of oceanic sediments. Int. Assoc. Sedimentol., Spec. Publ., 1:301-326.

Date of Initial Receipt: 30 August 1985

Date of Acceptance: 27 August 1986 